NATIONAL LABORATORY

MANAGED BY UT-BATTELLE

FOR THE DEPARTMENT OF ENERGY

\title{
Deployment of Alumina Forming Austenitic (AFA) Stainless Steel
}

\section{September 30, 2013}

Prepared by

Michael P. Brady, Yukinori Yamamoto, Govindarajan Muralidharan, Hiram Rogers and Bruce A. Pint

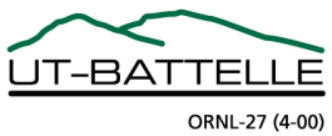




\title{
DOCUMENT AVAILABILITY
}

Reports produced after January 1, 1996, are generally available free via the U.S. Department of Energy (DOE) Information Bridge.

Web site http://www.osti.gov/bridge

Reports produced before January 1, 1996, may be purchased by members of the public from the following source.

\author{
National Technical Information Service \\ 5285 Port Royal Road \\ Springfield, VA 22161 \\ Telephone 703-605-6000 (1-800-553-6847) \\ TDD 703-487-4639 \\ Fax 703-605-6900 \\ E-mailinfo@ntis.gov \\ Web site http://www.ntis.gov/support/ordernowabout.htm
}

Reports are available to DOE employees, DOE contractors, Energy Technology Data Exchange (ETDE) representatives, and International Nuclear Information System (INIS) representatives from the following source.

Office of Scientific and Technical Information

P.O. Box 62

Oak Ridge, TN 37831

Telephone 865-576-8401

Fax 865-576-5728

E-mail reports@osti.gov

Web site http://www.osti.gov/contact.html

This report was prepared as an account of work sponsored by an agency of the United States Government. Neither the United States Government nor any agency thereof, nor any of their employees, makes any warranty, express or implied, or assumes any legal liability or responsibility for the accuracy, completeness, or usefulness of any information, apparatus, product, or process disclosed, or represents that its use would not infringe privately owned rights. Reference herein to any specific commercial product, process, or service by trade name, trademark, manufacturer, or otherwise, does not necessarily constitute or imply its endorsement, recommendation, or favoring by the United States Government or any agency thereof. The views and opinions of authors expressed herein do not necessarily state or reflect those of the United States Government or any agency thereof. 
ORNL/TM-2013/479

Advanced Manufacturing Office

\title{
Deployment of Alumina Forming Austenitic (AFA) Stainless Steel Final Report
}

August 31, 2009 to September 30, 2013

\author{
Author \\ Bruce A Pint \\ (865) 576-2897 \\ pintba@ornl.gov
}

ORNL Co-Authors: Michael P. Brady, Yukinori Yamamoto,

Govindarajan Muralidharan, Hiram Rogers

Project Team Members:

Carpenter Technology Corp.

Capstone Turbine Corp.

Solar Turbines, Inc

United Technologies Research Center

University of Connecticut

Duraloy Technologies, Inc.

Date Published: September, 2013

\author{
Prepared by \\ OAK RIDGE NATIONAL LABORATORY \\ Oak Ridge, Tennessee 37831-6283 \\ managed by \\ UT-BATTELLE, LLC \\ for the \\ U.S. DEPARTMENT OF ENERGY \\ under contract DE-AC05-00OR22725
}





\section{CONTENTS}

LIST OF FIGURES

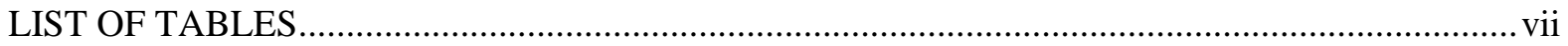

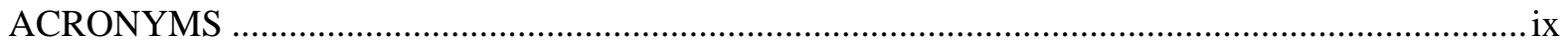

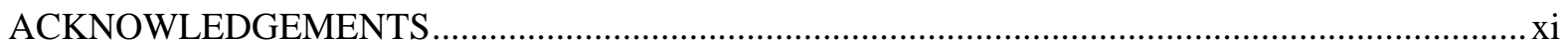

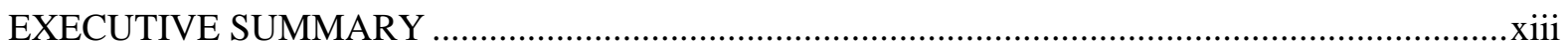

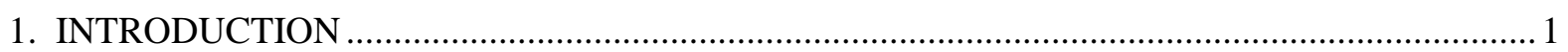

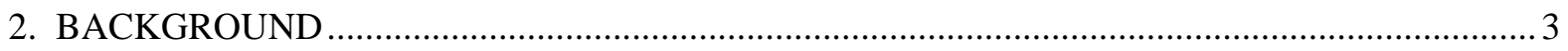

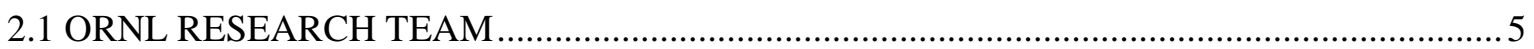

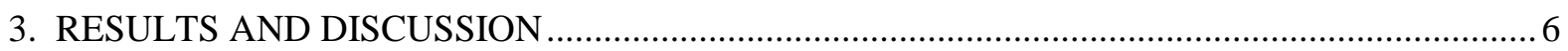

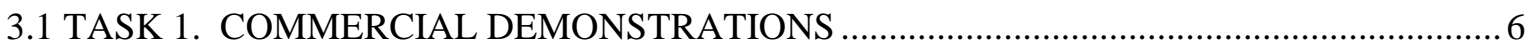

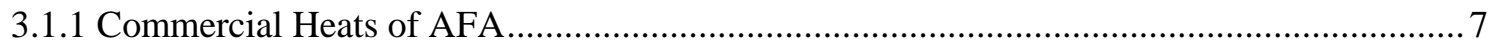

3.1.2 Capstone Turbine Corporation Demonstration................................................................ 8

3.1.3 United Technologies Research Center Commercial Demonstration ................................. 9

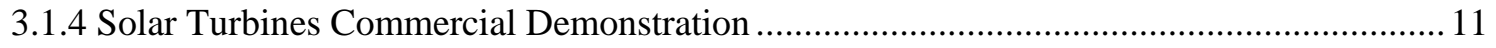

3.1.5 Duraloy Technologies, Inc. Commerical Demonstration ............................................... 12

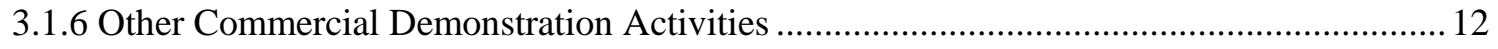

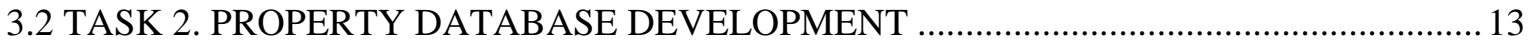

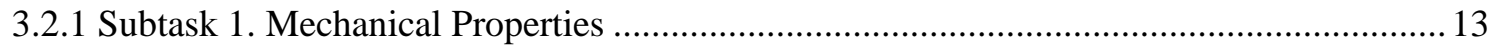

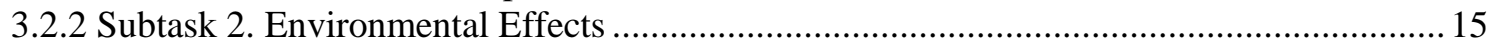

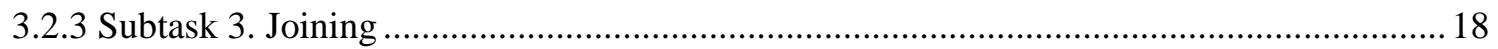

3.2.4 Subtask 4. Physical Properties ...................................................................................... 19

3.2.5 Creep and Oxidation Resistance of the Commercial OC4 Foil Batches............................20

3.3 TASK 3. ALLOY DEVELOPMENT AND OPTIMIZATION .............................................. 24

3.3.1 Low Cost AFA Alloy Compositions for Tube Applications ............................................28

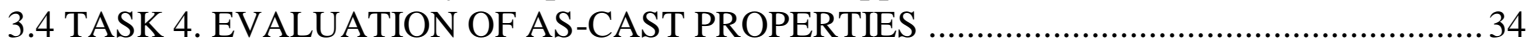

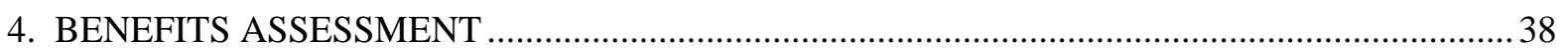

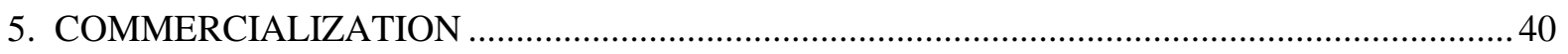

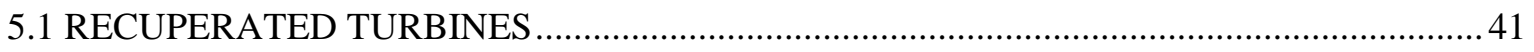

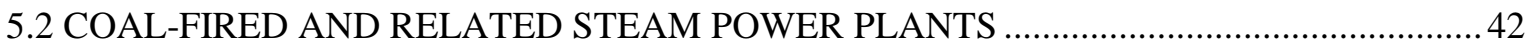

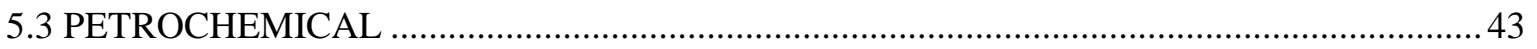

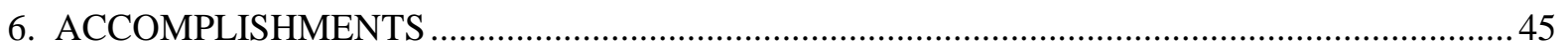

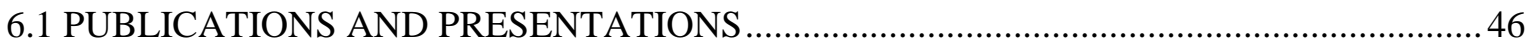

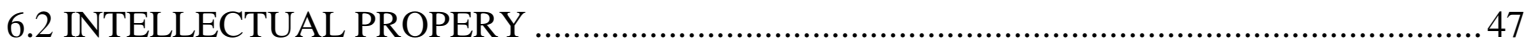

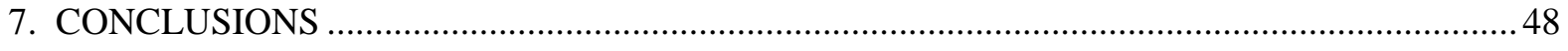

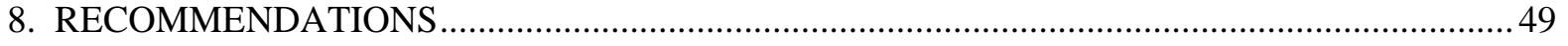





\section{LIST OF FIGURES}

Fig. 1. Schematic representation of (a) oxide growth rate data, and (b) thermodynamic stability data for

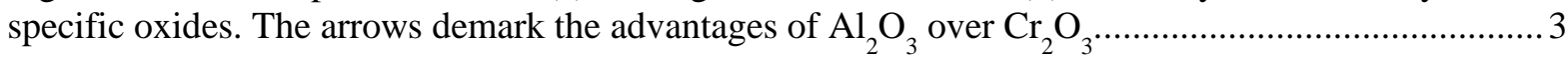

Fig.2. Commercialization effort overview of baseline AFA OC4 alloy processing and component

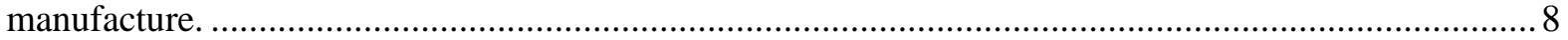

Fig 3. AFA foil air cell manufactured at Capstone incorporating foil and wire AFA product forms..... 9

Fig. 4. Chromium evaporation rates of AFA OC4 at 800-900C in air with $3 \%$ water vapor 9 (after

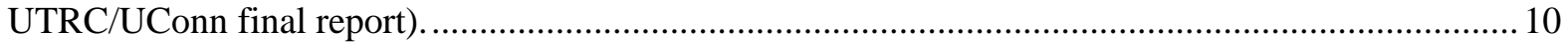

Fig. 5. Chromium evaporation rates of AFA OC4 at $850^{\circ} \mathrm{C}$ in air with $3 \%$ water vapor relative to

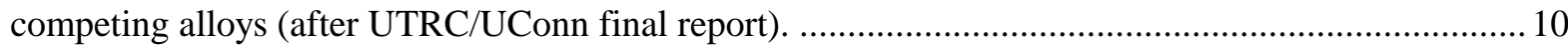

Fig. 6. Braze joint showing excellent joining of AFA foil (left) and subscale heat exchanger with folded AFA foil (right) (after UTRC/UConn final report)............................................................ 11

Fig. 7. Panels of folded AFA OC-4 foil to be welded into Mercury 50 turbine by Solar Turbines, Inc.

Fig. 8. Cast AFA tube made at Duraloy Technologies.

Fig. 9. Variation in $0.2 \%$ yield (solid lines) and tensile strength (broken lines) with temperature for

AFA composition OC4 compared to two commercial alloys.......................................................... 13

Fig. 10. Larson Miller Parameter plot of alloy OC4 creep rupture data plotted as a function of stress

along with some benchmark commercial high temperature austenitic stainless steels (347, Super 304H

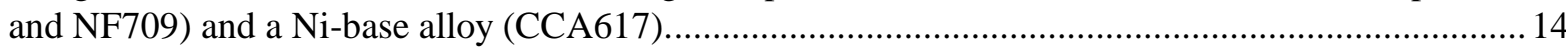

Fig. 11. Minimum creep rate of AFA alloy $\mathrm{OC} 4$ plotted as a function of stress at $650^{\circ} \mathrm{C}$ (circle),

$700^{\circ} \mathrm{C}$ (square), and $750^{\circ} \mathrm{C}$ (triangle) compared to alloy HR6W (lines)........................................... 14

Fig. 12. Room temperature low cycle fatigue data: (a) cycles to failure for AFA alloy OC4 compared to type 316 and 347 stainless steels; the strain rates were either 0.5 or $2 \mathrm{~s}-1$, as noted, with a total strain of $1 \%$ and (b) effect of solution annealing at $650^{\circ}$ and $750^{\circ} \mathrm{C}$ on lifetime. .................................... 15

Fig. 13. Light microscopy of polished cross-sections after long term exposures in air at $800^{\circ} \mathrm{C}$ (a)

AFA after 10,000h, (b) alloy 120 after 10,000h and (c) cast CF8C after only 5,000h. ..................... 16

Fig. 14. Mass gains for coupons exposed in $500 \mathrm{~h}$ cycles at $800^{\circ} \mathrm{C}$ in $17 \mathrm{bar}$ steam. ........................... 16

Fig. 15. Specimen mass change for AFA OC4 compared to HR 120 and $347 \mathrm{H}$ in three different environments for $5,000 \mathrm{~h}$. The $347 \mathrm{H}$ specimens were stopped at shorter times because of the severe attack observed.

Fig. 16. Mass change for different alloys compared to AFA OC4 after 500h exposures at four different conditions with increasing $\mathrm{H} 2 \mathrm{O}$ contents. The pressure was increased from 1 to $16 \mathrm{~atm}$ in the

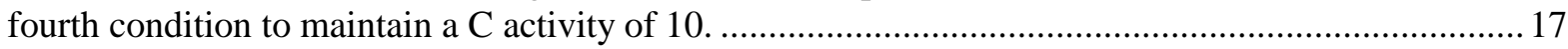

Fig. 17. Welded 10mm OC4 plate being machined into creep specimens....................................... 18

Fig. 18. Applied stress plotted against the Larson-Miller Parameter for creep tests of OC4 base metal

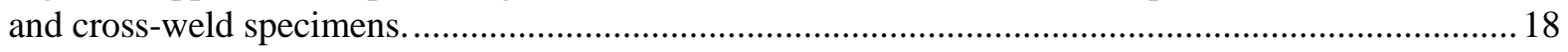

Fig. 19. Stamped bellows segments made from AFA foil. ......................................................... 19

Fig. 20. (a) Mean thermal expansion and (b) thermal conductivity of OC4 and other alloys as a

function of temperature............................................................................................................. 19

Fig. 21. (a) Specific heat capacity and (b) electrical resistivity of OC4 and other alloys as a function of

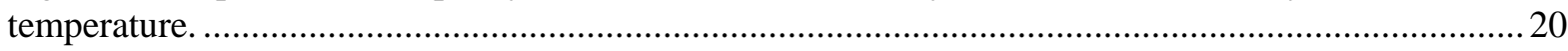

Fig. 22. Variation in (a) Young's modulus and (b) Poisson's ratio for OC4 as a function of temperature.

Fig. 23. Light microscopy of the longitudinal cross section of the AFA foils (a) $80 \mu \mathrm{m}$ "A" and (b) $150 \mu \mathrm{m}$ "B".

Fig. 24. Specimen mass change of commercial OC4 foil coupons after 4,000h exposures at each temperature in wet air. The ticks on the bars show a standard deviation for multiple specimens. .22 
Fig. 25. Light microscopy images of polished cross sections of OC4 foils exposed for $1000 \mathrm{~h}$ in air + $10 \% \mathrm{H} 2 \mathrm{O}$, (a,b) $150 \mu \mathrm{m}, 650^{\circ} \mathrm{C}$, (c) $80 \mu \mathrm{m}, 650^{\circ} \mathrm{C}$, (d,e) $150 \mu \mathrm{m}, 700^{\circ} \mathrm{C}$, (f,g) $80 \mu \mathrm{m}, 700^{\circ} \mathrm{C}$, (h,i) $150 \mu \mathrm{m}, 750^{\circ} \mathrm{C}$, (j,k) $80 \mu \mathrm{m}, 750^{\circ} \mathrm{C},(\mathrm{l}, \mathrm{m}) 150 \mu \mathrm{m}, 800^{\circ} \mathrm{C}$, (n) $80 \mu \mathrm{m}, 800^{\circ} \mathrm{C}$. Mainly thin, protective $\mathrm{Al}-$ rich oxides are found at each temperature.

Fig. 26. Creep curves at $750^{\circ} \mathrm{C}$ with an applied stress of $100 \mathrm{MPa}$ for the three new commercial batches of AFA foil. For comparison, older batches are shown. 23

Fig. 27. Sections of foil recuperators in macro and light microscopy polished cross-sections (a,c) $80 \mu \mathrm{m}$ AFA OC4 foil and (b,d) alloy 120 foil. 23

Fig. 28. Computational thermodynamic predictions for OC-4 and SEM image showing a small amount of sigma formation after $2000 \mathrm{~h}$ ageing of OC-4 at $650^{\circ} \mathrm{C}$.

Fig. 29. Computational thermodynamic predictions for sigma phase and SEM image microstructures observed in modified OC-4 alloy AFA 24 and AFA 27 after $2000 \mathrm{~h}$ ageing of OC-4 at $650^{\circ} \mathrm{C} \ldots \ldots \ldots .25$

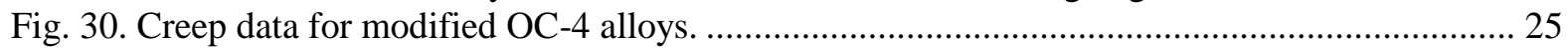

Fig. 31. Computational thermodynamic predictions for MC supersaturation vs $\mathrm{Nb}$ content for modified

OC-4 compositions and corresponding TEM bright field images after creep testing. ......................... 26

Fig. 32. TEM bright field images for modified OC-4 compositions after creep testing at $650^{\circ} \mathrm{C}$....... 27

Fig. 33. Mass gain of modified AFA alloys exposed in $10 \mathrm{~h}$ cycles at $900^{\circ} \mathrm{C}$ in air with $10 \% \mathrm{H} 2 \mathrm{O} \ldots 28$

Fig. 34. Creep rupture life curves for low cost AFA alloys OC-G and OC-I. ................................... 30

Fig. 35. Larson-Miller Parameter (LMP) creep plot update for low cost AFA alloys. ...................... 31

Fig. 36. Oxidation data for baseline and modified low Ni AFA alloys ON-N - OC-R, OC-G, and OC-I relative to $25 \% \mathrm{Ni}$ AFA alloy $\mathrm{OC}-5\left(800^{\circ} \mathrm{C}\right.$ only) and commercial austenitics at $700^{\circ}$ and $800^{\circ} \mathrm{C}$ in air $+10 \% \mathrm{H} 2 \mathrm{O}$.

Fig. 37. OC-4 and OC-I rods manufactured by ORNL for gradient metal dusting condition evaluation.

Fig. 38. Computational thermodynamic calculation results used to guide and assess candidate cast

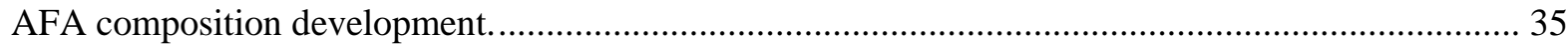

Fig. 39. Creep strain as a function of time for candidate cast alloys vs the OC-4 base. ..................... 35

Fig. 40. Larson-Miller parameter creep resistance plot showing the cast AFA alloys relaive to cast

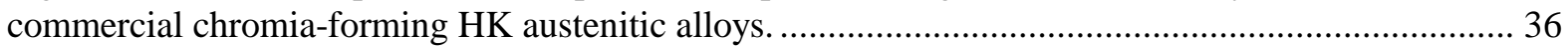

Fig. 41. Oxidation data at $800^{\circ} \mathrm{C}$ in air with $10 \%$ water vapor showing the cast AFA alloys relative to cast commercial chromia-forming HK and HP austenitic alloys................................................. 36 


\section{LIST OF TABLES}

Table 1. Overview of the AFA alloy family.....

Table 2. Hardness values for the as received and recuperator AFA and H120 foils ..........................2 24

Table 3. Nominal compositions of select exploratory modified OC-4 alloys....................................24

Table 4. Analyzed compositions of AFA alloys studied for increase upper temperature oxidation limit

Table 5. Effect of annealing temperature on creep rupture lifetime .................................................29

Table 6. Carpenter creep rupture data for low cost, lower Ni AFA alloy heats .................................. 32

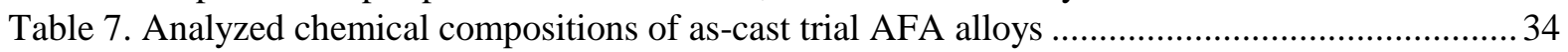

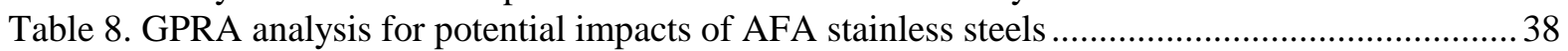

Table 9. Revised GPRA analysis for potential impacts of AFA stainless steels ...................................39

Table 10. Overview of potential AFA applications and estimated degree of commercialization promise

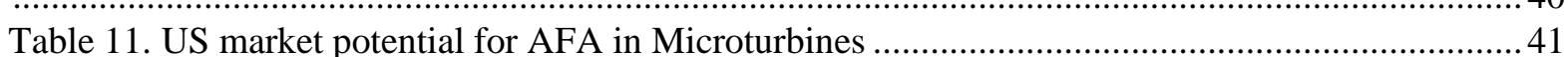

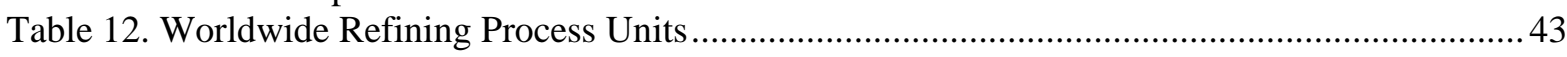

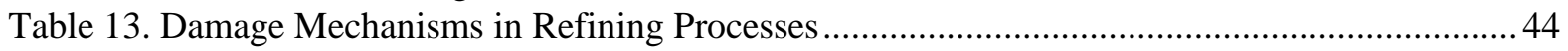




\section{ACRONYMS}

AFA

AMO

API

ARRA

ASME

ASTM

Btu

CHP

CRADA

CW

DARPA

DG

DOE

EERE

EIA

EPRI

FCC

GPRA

$\mathrm{h}$

kh

KW

MECS

$\mathrm{MPa}$

MW

OD

SA

SEM

SOFC

TCE

TEM

TRI

ORNL

US

USC

UTRC

Wt.\%
Alumina-forming Austenitic

Advanced Manufacturing Office

American Petroleum Institute

American Recovery and Reinvestment Act

American Society of Mechanical Engineers

American Standards for Testing Materials

British Thermal Unit

Combined Heat and Power

Cooperative Research and Development Agreement

Cold Work

Defense Advanced Research Projects Agency

Distributed Generation

Department of Energy

Office of Energy Efficiency and Renewable Energy

Energy Information Agency

Electric Power Research Institute

Fluid Catalytic Cracking

Government Performance and Results Act

hours

Thousand hours

Kilowatt

Manufacturing Energy Consumption Survey

Megapascal

Megawatt

Outer Diameter

Solution Annealed

Scanning Electron Microscopy

Solid Oxide Fuel Cell

Tons of Carbon Equivalent

Transmission Electron Microscopy

ThermoChem Recovery International, Inc.

Oak Ridge National Laboratory

United States

Ultra Super Critical

United Technologies Research Center

Weight percent 


\section{ACKNOWLEDGEMENTS}

This report is based upon work supported by the Advanced Manufacturing Office (AMO) of the U. S. Department of Energy (DOE) under CPS Agreement 20909 via the Advanced Materials R\&D in Support of EERE Needs to Advance Clean Energy Technologies Program of the American Recovery and Reinvestment Act (ARRA) of 2009. 


\section{EXECUTIVE SUMMARY}

The purpose of the project was to accelerate the deployment and further the development of a new family of heat-resistant alloys developed at ORNL: alumina-forming austenitic (AFA) stainless steels. Initial laboratory scale evaluation indicated that AFA alloys possess exceptional high-temperature oxidation resistance while retaining creep properties similar to other advanced austenitic stainless steels. The AFA steels therefore represent a low-cost alternative to Ni-base alloys and a highperformance alternative to conventional advanced austenitic steels. Deployment of AFA steels into turbine and other energy-related applications can lead to improved efficiencies by achieving higher operating temperatures and/or improved durability and component lifetime at costs comparable to currently used alloys. The development and scale up of optimized AFA alloy compositions in both wrought and cast forms, including generation of a database of thermo-physical, mechanical, welding/joining, and high-temperature corrosion properties was needed to enable consideration and adoption of these new materials in applications ranging from turbines, heat exchangers, and fuel cells to boilers and chemical/petrochemical processing. The project consisted of four primary tasks: commercial demonstrations, property database development, alloy development and optimization and evaluation of as-cast properties.

Multiple scale up and commercial demonstration activities were pursued, with an emphasis on gas turbine recuperator and heat exchanger applications. Formal projects were completed with United Technologies Corp. and Capstone Turbine Corp. and cost-share was also obtained on collaborations with Carpenter Technology Corp., Duraloy Technologies and Solar Turbines. AFA material was successfully produced in strip, foil, and tube form, including a successful 10,000lb production heat by Carpenter, which licensed the AFA alloy patents in 2011. A database was completed for a baseline AFA alloy that was summarized in an alloy data sheet which included mechanical properties, hightemperature corrosion resistance, joining characteristics, and thermo-physical properties needed by potential industrial end users to assess AFA. Several new grades of AFA alloy also were developed, including a cast form of AFA with a promising combination of creep and oxidation resistance. A patent was awarded for cast AFA and it was successfully centrifugally cast in tube form by an industrial collaborator. Evaluation of AFA alloys by industrial collaborators, as well as marketing and scale up activities by Carpenter will continue beyond the conclusion of this project as various AFA alloy compositions continue to progress into commercial applications. 



\section{INTRODUCTION}

The purpose of the project was to accelerate the development and deployment of a new family of heatresistant alloys developed at ORNL: alumina-forming austenitic (AFA) stainless steels. Initial laboratory scale evaluation indicated that the AFA alloys possess exceptional high-temperature oxidation resistance while retaining creep properties similar to other advanced austenitic stainless steels. The AFA steels therefore represent a low-cost alternative to Ni-base alloys and a highperformance alternative to conventional advanced austenitic steels. Deployment of AFA steels into turbine and other energy-related applications can lead to improved efficiencies by achieving higher performance levels (e.g. operation temperature) and/or improved durability and component lifetime at costs comparable to currently used alloys. The development and scale up of optimized AFA alloy compositions in both wrought and cast forms, including generation of a database of thermo-physical, mechanical, welding/joining, and high-temperature corrosion properties was needed to enable consideration and adoption of these new materials in applications ranging from turbines, heat exchangers, and fuel cells to boilers and chemical/petrochemical processing.

This project consisted of four primary tasks:

Task 1. Commercial Demonstrations

Task 2. Property Database Development

Task 3. Alloy Development and Optimization

Task 4. Evaluation of As-Cast Properties

The task 1 commercial demonstrations included an open solicitation process for industrial demonstration of AFA components in various applications. Capstone Turbine Corporation was selected for demonstration of AFA alloy recuperators for their high efficiency microturbines. United Technologies Corp. and partner University of Connecticut were selected for evaluation of AFA alloys for solid oxide fuel cell (SOFC) balance of plant heat exchangers. An additional demonstration effort was initiated with Solar Turbines, Inc for evaluation of AFA alloys for use as a recuperator in their Mercury 50 4.6MW turbine gas turbine. Carpenter Technology Corporation, a leading US specialty alloy manufacturer, licensed the AFA alloy family on April 7, 2011 and participated in scale up activities, including manufacture of $400 \mathrm{lb}$ trial heats and a 10,000 lb production heat, which was used to supply AFA material to industrial partners for evaluation.

The Task 2 property database development focused on an initially down selected AFA composition, alloy OC-4 (Fe-25Ni-14Cr-3.5Al-2.5Nb-2Mn-2Mo-1W-0.1C-0.01B wt.\% base). Trial scale wrought OC-4 alloy material manufactured by conventional industrial processes was provided to the project team by Carpenter. The initial promising AFA alloy oxidation and mechanical properties data were obtained at a screening level and generated from small $(<1 \mathrm{lb})$ lab-scale heats. Far more extensive property information from industrially produced heats is needed by industrial end users considering adoption of AFA alloys. This data is used to make the necessary engineering and cost-benefit analyses that will lead to the selection of AFA steels. Property evaluation pursued included mechanical properties (creep, tensile, and fatigue), environmental effects (multiple types of high temperature corrosion environments), thermo-physical properties, and joining.

The purpose of the alloy development and optimization Task 3 was to investigate modified AFA compositions that (1) improve on the initially observed properties, (2) reduce alloy cost, or (3) address manufacturing issues that may arise during manufacturing scale up to commercial production. This work included study of variation in minor alloying addition levels to assist Carpenter in identifying 
AFA alloy specification ranges to achieve target properties, as well as to explore several grades of AFA alloy performance and cost levels to provide the basis for commercial adoption in a wide range of potential end uses. Tasks 1-3 were focused on initially developed wrought AFA alloys. However, some applications such as turbine casings and ducts or tubes require manufacture from as-cast alloys. The goal of Task 4 evaluation of as-cast properties was to assess the feasibility of cast forms of AFA alloys. This required modification of AFA alloy base compositions to yield high levels of property performance in as-cast structures. This work led to an additional AFA alloy patent for cast forms of AFA (Cast Alumina Forming Austenitic Stainless Steels, US 8,431,072 B2 Apr. 30, 2013) and a successful trial scale tube manufacture by Duraloy Technologies, Inc. 


\section{BACKGROUND}

The alumina-forming austenitic (AFA) stainless steels are a new class of high-temperature $\left(\sim 500-950^{\circ} \mathrm{C} ; 1112-\right.$ $1742^{\circ} \mathrm{F}$ ) structural stainless steel alloy family with the potential for widespread applicability in the chemical/petrochemical process and energy production industries. These steels combine the relatively low cost, excellent formability, weldability, and good high-temperature creep strength of state-of-the-art advanced austenitic stainless steels with fundamentally superior high-temperature corrosion resistance due to their ability to form protective aluminum oxide (alumina, $\mathrm{Al}_{2} \mathrm{O}_{3}$ ) surface layers.

Conventional high-temperature stainless steels rely on chromium-oxide (chromia, $\mathrm{Cr}_{2} \mathrm{O}_{3}$ ) surface layers for protection from high-temperature corrosion. However, compromised corrosion resistance of chromia in the presence of aggressive species such as water vapor, carbon, sulfur, etc., typically encountered in process and energy production environments necessitates a reduction in operating temperature to achieve component durability targets. This temperature reduction reduces process efficiency and increases environmental emissions.

Alumina grows at a rate $\sim 1$ to 2 orders of magnitude (10-20 times) lower than chromia and is also significantly more thermodynamically stable in oxygen, which contributes to its fundamentally superior high-temperature corrosion resistance (Fig. 1). The AFA stainless steels are a new thermal and degradation resistant material with the potential to increase component lifetime by up to a factor of ten or increase upper temperature use by $\sim 50$ $200^{\circ} \mathrm{C}\left(\sim 100-400^{\circ} \mathrm{F}\right)$ over conventional chromia-forming stainless steel alloys. Such improvements can lead to increased efficiencies in energy conversion and combustion system applications. Alumina scales have typically proven to be particularly beneficial in laboratory test environments containing aggressive carbon- or sulfurspecies such as those typically encountered in chemical and petrochemical process industry applications. A further key advantage of alumina over chromia is its greater stability in the presence of water vapor. Water vapor is encountered as a component in many high-temperature industrial environments (e.g.

chemical/petrochemical processing, steam boilers, combustion and gasification-particularly biomass). With both oxygen and water vapor present, volatile chromium oxy-hydroxide species can form and significantly reduce component lifetime.
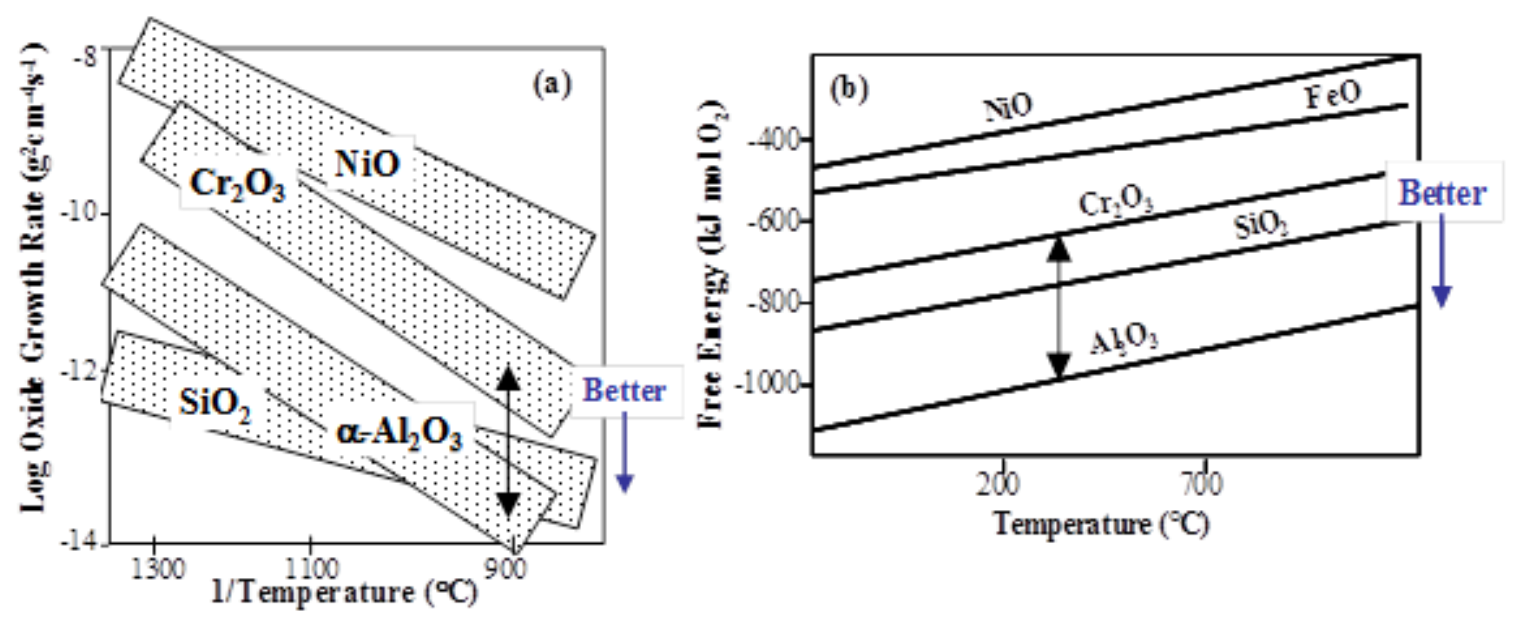

Fig. 1. Schematic representation of (a) oxide growth rate data, and (b) thermodynamic stability data for specific oxides. The arrows demark the advantages of $\mathrm{Al}_{2} \mathrm{O}_{3}$ over $\mathrm{Cr}_{2} \mathrm{O}_{3}$.

Despite the many advantages of protective alumina layer formation, all cast/wrought Fe-base hightemperature structural alloys available today for use above $\sim 600^{\circ} \mathrm{C}\left(1112^{\circ} \mathrm{F}\right)$ use chromia surface layers for protection. This is due to the extensive solid solubility and excellent metallurgical compatibility of chromium $(\mathrm{Cr})$ in iron/iron-nickel $\mathrm{Fe} / \mathrm{Fe}(\mathrm{Ni})$, which permits ready formation of 
protective chromia with ample alloy design flexibility to co-optimize corrosion resistance with other needed properties such as creep resistance, weldability, etc. Numerous attempts have been made by alloy developers worldwide over the past 30 years to create creep-resistant alumina-forming, ironbased austenitic stainless steels for use as high-temperature structural alloys, but none have succeeded sufficiently in balancing alloy cost, corrosion, and creep resistance. The underlying challenge is that the addition of aluminum ( $\mathrm{Al}$ ) to iron ( $\mathrm{Fe}$ ) results in a loss of alloy creep strength by stabilizing the weak ferritic form of $\mathrm{Fe}$ at the expense of the stronger austenitic Fe form. Ferritic FeCrAl-based alloys capable of alumina formation have long been available for specialty applications such as heating elements, catalyst support beds, and furnace liners, but they are too weak for high-temperature structural use. Alumina-forming, Ni-base alloys with excellent creep resistance are also available, but are far too costly for many applications, at least 3 to 5 times more expensive than austenitic stainless steels.

The AFA alloys therefore represent a potentially significant technological break-through as there are no comparable creep-resistant, Fe-base alumina-forming austenitic alloys available today. The first archival journal paper presenting the alloy design principles and technological break-through promise of AFA alloys was published in the international, multi-disciplinary journal Science (April 20, 2007 issue), attesting to its widespread scientific and technological importance and uniqueness. The AFA alloy family was recognized with a R\&D 100 Award in 2009 as one of the year's top 100 technological developments as selected by R\&D Magazine. Under the auspices of the present project, the three core AFA alloy family patents were licensed by Carpenter Technology Corporation on April 7, 2011. Carpenter participated in several AFA related CRADAs as well as the present project by activities related to the manufacture and scale up assessment of AFA alloys.

Three key findings underpin the successful development of the AFA alloy family:

1. Protective alumina surfaces can be formed on austenitic stainless steels with only 2.5-4 weight percent (wt.\%) $\mathrm{Al}$ and 12-15 wt.\% Cr. (Cr aids in the establishment of the alumina surface). These relatively low levels of $\mathrm{Al}$ and $\mathrm{Cr}$ (also a ferritic Fe stabilizer) permit stabilization of a strong austenitic matrix microstructure at comparable Ni levels to conventional austenitic stainless steels ( $12-30 \mathrm{wt} . \%$ $\mathrm{Ni}$ depending on $\mathrm{Al} / \mathrm{Cr}$ content).

2. The addition of 0.6-3 wt.\% niobium $(\mathrm{Nb})$ synergistically enhances the formation of an alumina surface layer by Al-modified austenitic stainless steels. The use of commonly used strengthening additions of nitrogen $(\mathrm{N})$, titanium (Ti), and vanadium $(\mathrm{V})$ degrade the ability to form an alumina surface layer in the AFA composition range and must be minimized.

3. Good creep resistance can be achieved in AFA stainless steels via niobium-carbide (NbC) and $/ \mathrm{o} \mathrm{M}_{23} \mathrm{C}_{6}(\mathrm{M}=\mathrm{Cr}, \mathrm{Nb}$, etc. $)$ nanoprecipitates.

The AFA stainless steels represent a new alloy design approach to austenitic stainless steels and have resulted in development of a new family of alloys, not a single composition grade. All of the AFA compositions exhibit a transition from protective alumina layer formation to internal oxidation of $\mathrm{Al}$ (and nonprotective corrosion behavior) if the temperature is raised too high, i.e., they have a defined upper-temperature performance limit for their good corrosion resistance. This is a consequence of the relatively low levels of $\mathrm{Al}$ and $\mathrm{Cr}$ used in AFA alloys to achieve the needed balance of mechanical properties with corrosion resistance. Several separate and distinct grade ranges of AFA alloys have been identified, each representing different balance points of alloy cost, creep strength, and uppertemperature limit for corrosion resistance. These include a baseline AFA grade, a low cost, low $\mathrm{Ni} /$ high $\mathrm{Mn}$ grade $\mathrm{AFA}^{\mathrm{LN}}$, a high performance, high upper temperature limit $\mathrm{AFA}^{\mathrm{HP}}$ grade, a cast AFA grade, and a $\gamma^{\prime}-\mathrm{Ni}_{3} \mathrm{Al}$ strengthened AFA superalloy grade. The present effort focused on initial scale up and manufacturing of the baseline AFA alloy grade, and exploration and optimization of the remaining AFA alloy grades. 
Table 1. Overview of the AFA alloy family

\begin{tabular}{|c|c|c|c|}
\hline Designation & Composition wt. $\%$ base & Corrosion limit & Comments \\
\hline AFA & $\begin{array}{l}(50-60) \mathrm{Fe}-(20-25) \mathrm{Ni}-(14- \\
15) \mathrm{Cr}-(2.5-3.5) \mathrm{Al}-(1-3) \mathrm{Nb}- \\
2 \mathrm{Mn}-(0-4) \mathrm{Mo} / \mathrm{W}-0.5 \mathrm{Cu} \\
+\mathrm{B}, \mathrm{C}, \mathrm{P}\end{array}$ & $\begin{array}{l}\text { Up to } \sim 700-850^{\circ} \mathrm{C} \\
\left(1292-1562^{\circ} \mathrm{F}\right)\end{array}$ & $\begin{array}{l}\text { Baseline AFA alloy } \\
\text { composition range }\end{array}$ \\
\hline $\mathrm{AFA}^{\mathrm{LN}}$ (low Ni) & $\begin{array}{l}\text { 63Fe-12Ni-14Cr-2.5Al- } \\
0.6 \mathrm{Nb}-5 \mathrm{Mn}-3 \mathrm{Cu}+\mathrm{B}, \mathrm{C}\end{array}$ & Up to $\sim 650^{\circ} \mathrm{C}\left(1202^{\circ} \mathrm{F}\right)$ & $\begin{array}{l}\text { Lower-cost, low-Ni AFA } \\
\text { alloy }\end{array}$ \\
\hline $\begin{array}{l}\mathrm{AFA}^{\mathrm{HP}} \\
\text { performance) }\end{array}$ & $\begin{array}{l}(45-55) \mathrm{Fe}-(25-30) \mathrm{Ni}-(12- \\
15) \mathrm{Cr}-(3.5-4.5) \mathrm{Al}-(1-3) \mathrm{Nb}- \\
0.1 \mathrm{Hf} \text { or } \mathrm{Zr}-0.02 \mathrm{Y}-2 \mathrm{Mn}-(0- \\
\text { 4) } \mathrm{Mo} / \mathrm{W}-0.5 \mathrm{Cu}+\mathrm{B}, \mathrm{C}, \mathrm{P}\end{array}$ & $\begin{array}{l}\text { Up to } \sim 800-950^{\circ} \mathrm{C} \\
\left(1472-1742^{\circ} \mathrm{F}\right)\end{array}$ & $\begin{array}{l}\text { Higher } \mathrm{Al} / \mathrm{Ni} \text { levels and } \\
\mathrm{Hf} / \mathrm{Zr} \text { or Y reactive } \\
\text { element additions increase } \\
\text { corrosion resistance }\end{array}$ \\
\hline Cast AFA & $\begin{array}{l}50 \mathrm{Fe}-25 \mathrm{Ni}-14 \mathrm{Cr}-3.5 \mathrm{Al}-1 \mathrm{Nb}- \\
2 \mathrm{Mn}-(0-4) \mathrm{Mo} / \mathrm{W}-0.5-1 \\
0.5 \mathrm{Cu}-(0.2-0.5) \mathrm{C}+\mathrm{B}\end{array}$ & $\begin{array}{l}\text { Up to } \sim 750-850^{\circ} \mathrm{C} \\
\left(1382-1562^{\circ} \mathrm{F}\right)\end{array}$ & Optimized for use as-cast \\
\hline AFA- superalloy' & $\begin{array}{l}(40-50) \mathrm{Fe}-(30-35) \mathrm{Ni}- \\
(14-19) \mathrm{Cr}-(2.5-3.5) \mathrm{Al}-3 \mathrm{Nb}+ \\
\mathrm{B}, \mathrm{C}, \mathrm{Ti}, \mathrm{Zr}\end{array}$ & $\begin{array}{l}\text { Up to } \sim 750-850^{\circ} \mathrm{C} \\
\left(1382-1562^{\circ} \mathrm{F}\right)\end{array}$ & $\begin{array}{l}\text { High creep strength } \gamma^{\prime}- \\
\mathrm{Ni}_{3} \mathrm{Al} \text { strengthened AFA } \\
\text { superalloy }\end{array}$ \\
\hline
\end{tabular}

\subsection{ORNL RESEARCH TEAM}

Bruce Pint (PI) has conducted research on high temperature materials for over 25 years and studied materials issues in coal-fired power plants for the past 20 years. He has been involved in several alloy development and commercial deployment projects of ORNL-invented materials, and is a co-inventor of the AFA alloy family. Michael Brady is the lead inventor of the AFA alloy family, and has over 20 years of experience in high-temperature alloy corrosion, alloy development, and materials synthesis. Yukinori Yamamoto is the co-lead inventor of the AFA alloy family, including lead inventor of the $\mathrm{AFA}^{\mathrm{LN}}$ and AFA superalloy grades, with over 15 years' experience in alloy design and physical and mechanical metallurgy. Govindarajan Muralidharan is the lead inventor of the cast AFA alloy grade and has over 20 years' experience in alloy design and materials processing and characterization. The welding/joining work was led by Michael Santella (now retired) who is a Fellow of the American Welding Society and is a co-inventor of the AFA alloy family. 


\section{RESULTS AND DISCUSSION}

This project was organized into four tasks:

Task 1. Commercial Demonstrations

Task 2. Property Database Development

Task 3. Alloy Development and Optimization

Task 4. Evaluation of As-Cast Properties

The first task was commercial demonstrations of AFA alloys. The property database development task 2 focused on creating a property database for an initially down selected AFA baseline grade composition, alloy OC-4 (Fe-25Ni-14Cr-3.5 Al-2.5Nb-0.1C wt.\% base), and included subtasks on mechanical properties, environmental effects, joining, and physical properties. The purpose of the alloy development and optimization Task 3 was to investigate modified AFA compositions that (1) improve on the initially observed properties, (2) reduce alloy cost, or (3) address manufacturing issues that may arise during manufacturing scale up to commercial production. Tasks 1-3 were focused on initially developed wrought AFA alloys. However, some applications such as turbine casings and ducts or tubes require manufacture from as-cast alloys. The goal of Task 4 evaluation of as-cast properties was to assess the feasibility of cast forms of AFA alloys.

\subsection{TASK 1. COMMERCIAL DEMONSTRATIONS}

An expression of interest for cost shared R\&D for commercial application of AFA was released on FedBizOps to advertise this funding opportunity to all interested parties. The request for proposals was released by ORNL procurement in November 2009, with three proposals received by the May 2010 deadline. Those proposals were evaluated and the results sent to ORNL procurement for negotiation, with two selected for funding.

Capstone Turbine Corporation was selected for demonstration of AFA alloy recuperators for highly efficient, 65kW microturbines, with the contract placed in January, 2011. United Technology Research Center and partner University of Connecticut (UConn) were selected for evaluation of AFA alloys for solid oxide fuel cell (SOFC) balance of plant heat exchangers, with the contract placed in June 2011. An additional cost-shared only demonstration effort was initiated with Solar Turbines, Inc for evaluation of AFA alloys for use as a recuperator in their Mercury 50 4.6MW turbine gas turbine. Carpenter Technology Corporation, a leading US specialty alloy manufacturer, licensed the AFA alloy family on April 7, 2011 and participated on a cost share basis in scale up activities, including manufacture of $400 \mathrm{lb}$ trial heats and a 10,000 lb production heat, which was used to supply AFA material to industrial partners for evaluation. A consultant was hired to assist in identifying additional markets for AFA, especially in the automotive industry. The consultant identified a number of additional markets for AFA that were pursued. In conjunction with Carpenter, samples of AFA alloy were distributed to a wide range of potential industrial end users and academic institutions for hightemperature corrosion evaluations. Duraloy Technologies, Inc. also made trial centrifugally cast AFA tubes based on the promising initial findings in Task 4.

Evaluation of AFA alloy test components and test coupons is ongoing by potential end users at the date of this report, in many cases long-term exposures are needed to validate the benefits of the AFA alloys over existing alloys. Manufacture of AFA material to deliver to end users was complex and time consuming with regards to delivering wrought product forms needed for evaluation. For example, 
AFA foil in recuperator applications was needed in 8 " widths and 3.2 mil thickness by one manufacturer, 16" widths and 4 mil thickness by another, and 6" width and 6 mil thickness by a third. This is due to the need to exactly match currently used alloy product form for which a particular company's manufacturing processes for components are established. Further complicating the situation, production of foil in these varying widths required the use of multiple industrial alloy postprocessers, as no one alloy processor had the capability to cast and work alloys from large heats to hot working to cold rolling to final foil product forms needed for evaluation. Many alloy post-processors were also unable to meet the initially targeted temperature and environmental control levels needed to optimally process AFA alloy (i.e., reducing atmosphere up to $1200^{\circ} \mathrm{C}$ ). Task 3 therefore was expanded to include work on development and evaluation of AFA alloy compositions that were amenable to lower-temperature post processing. Details of the commercial heats and major demonstration efforts are provided in the following subsections.

\subsubsection{Commercial Heats of AFA}

This section describes the alloy procurements that were needed to assist with the commercial demonstrations and the other technical tasks. The commercial alloy heat activities focused on the baseline AFA grade alloy OC-4 (Fe-25Ni-14Cr-3.5Al-2.5Nb-2Mn-2Mo-1W-0.1C-0.01B wt.\% base). This AFA alloy composition was selected because it exhibited protective alumina scale formation to $900^{\circ} \mathrm{C}$, which afforded its evaluation for a wide range of potential end use applications, driven primarily by the improved high-temperature corrosion resistance of the AFA alloy family. The creep resistance of OC-4 was sufficient for the applications evaluated, although its creep resistance subsequently proved to be on the lower end of the AFA composition range (details in Task 2 description). Modifications of OC-4 and related AFA grade alloys for improved creep were successfully identified (details in Task 3 description).

Figure 2 provides a photographic overview of some of the OC-4 commercial heat products and component fabrication and evaluation. In 2010, Carpenter successfully produced a 10,000lb production heat of OC-4. Portions of this material were hot and cold rolled by Carpenter and delivered to Elgiloy Specialty Metals for production of foil forms for Capstone recuperator manufacture and evaluation. Metalwerks, Inc. also produced a 2,300lb heat of AFA, which was used to manufacture wide foil needed by Solar Turbines and wire product form needed by Capstone. The Metalwerks AFA heat material was further processed by Haynes and Somers Thin Strip (a division of Olin Brass) and/or Elgiloy. Complications were encountered with the wide width foil when intermediate rolling was done below the needed $1200^{\circ} \mathrm{C}$ solutionizing temperature, which resulted in coarse $\mathrm{NbC}$ inclusions and foil cracking. Despite these complication, coil foil and wire product suitable for Capstone, Solar, and UTRC were manufactured and delivered for evaluation. Additional $20 \mathrm{lb}$ and $400 \mathrm{lb}$ heats of both OC4 and modified AFA compositions were successfully manufactured by Carpenter and used for evaluations in Tasks 2 and 3, as well as for test coupon material delivered to end multiple potential industrial users for evaluation. 


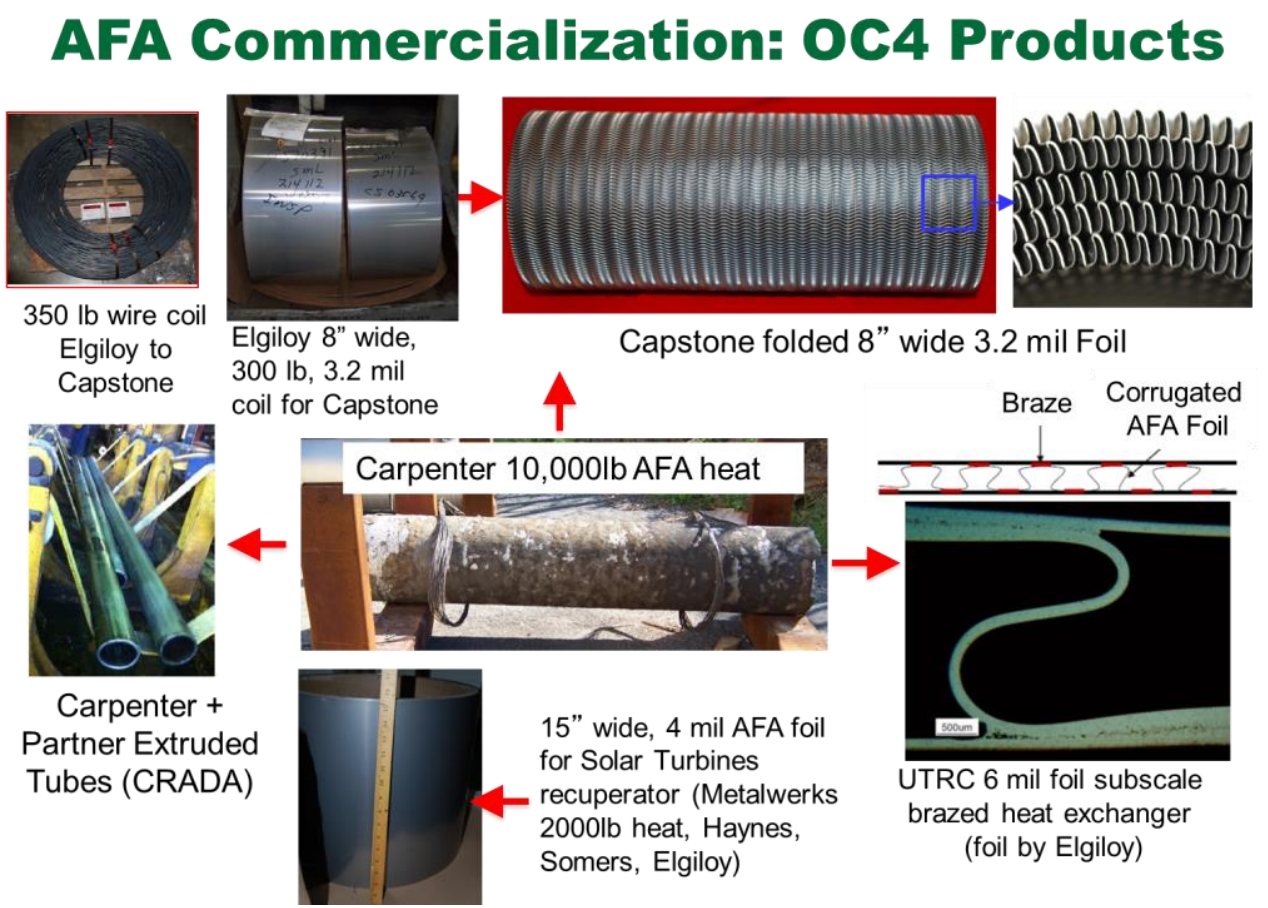

Fig.2. Commercialization effort overview of baseline AFA OC4 alloy processing and component manufacture.

\subsubsection{Capstone Turbine Corporation Demonstration}

The Capstone project was devoted to manufacture and turbine engine evaluation of AFA OC-4 foil recuperate air cells. In August, 2011 approximately 129 lbs. of commercial AFA foil with the specified thickness and width was manufactured in final form by Elgiloy and delivered to Capstone Turbine Corp. The foil was successfully folded with existing manufacturing processes and used to make air cells. In November 2011, three sizes of AFA wire were manufactured in final form by Elgiloy and delivered to Capstone Turbine Corp. AFA u-bar wire is bent to shape and welded to the air cell. An example of an in progress manufactured air cell is shown in Fig. 3. Some new material learning curve issues have been encountered in the final welding process, due to the suboptimal surface finish on the AFA wires (retained oxide) and welding parameter differences between AFA and the current Capstone material. At the date of this report, these complications are expected to be overcome and engine testing of the air cells initiated in 2013-2014. 


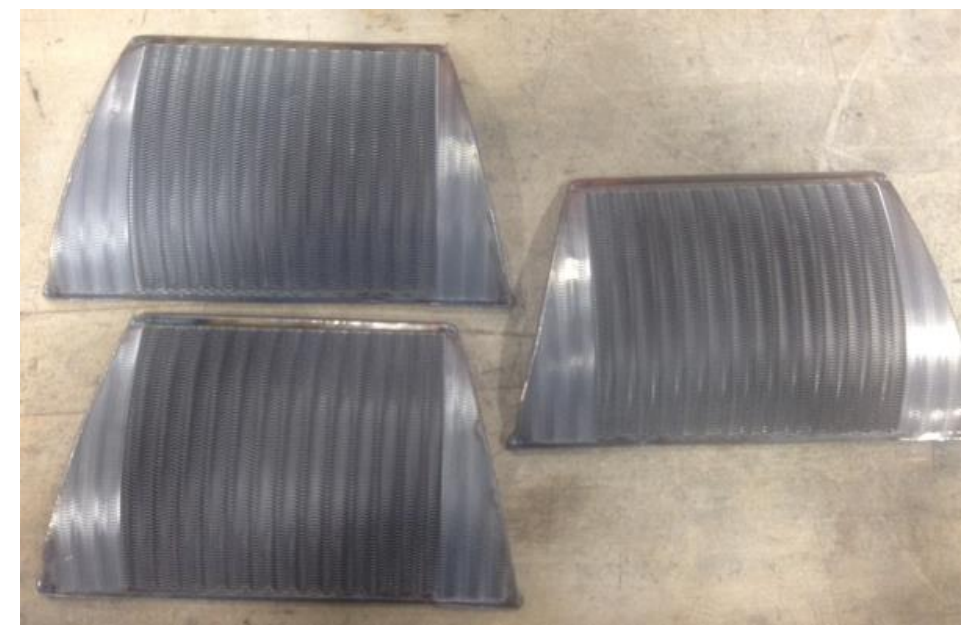

Fig 3. AFA foil air cell manufactured at Capstone incorporating foil and wire AFA product forms.

\subsubsection{United Technologies Research Center Commercial Demonstration}

The project at United Technologies (UT) Research Center and subcontractor University of Connecticut (UConn.) was devoted to evaluation of AFA alloys for solid oxide fuel cell (SOFC) balance of plant (BOP) heat exchanger applications. The AFA alloys are of interest as volatilization of $\mathrm{Cr}$ species from conventional chromia-forming alloys can contaminate the SOFC stack, resulting in degraded performance and stack lifetime. The goal of the project was to 1) evaluate the Cr volatilization rates from AFA relative to chromia-forming alloys and other alumina-forming alloys and 2) assess the potential to braze AFA foil for heat exchanger manufacture.

Figure 4 shows the Cr evaporation rates from AFA alloy OC- 4 after $500 \mathrm{~h}$ at 800,850 , and $900^{\circ} \mathrm{C}$ in air with $3 \%$ water vapor obtained by UConn. Placing the results in perspective, Fig. 5 shows $850^{\circ} \mathrm{C}$ data for OC-4 relative to the chromia-forming stainless steel type 310 (Fe-20Ni-25Cr base), aluminaforming $\mathrm{FeCrAl}$ (ferritic structure has inadequate creep resistance for the SOFC BOP application, and an aluminized Ni-base alloy (high cost). The AFA alloy exhibited $\mathrm{Cr}$ evaporations rates over an order of magnitude lower than that of type 310 stainless steel, although moderately higher than the FeCrAl and aluminized Ni-base alloys. The Cr present in the AFA alloys (Table 1) acts to aid the formation of the protective alumina surface, but does result in some oxidized $\mathrm{Cr}$ products. Although a set target for acceptable $\mathrm{Cr}$ evaporation rates is not yet defined, the low $\mathrm{Cr}$ evaporation rates observed for AFA suggest it is a potentially viable candidate for SOFC balance of plant in the $800-900^{\circ} \mathrm{C}$ range. 


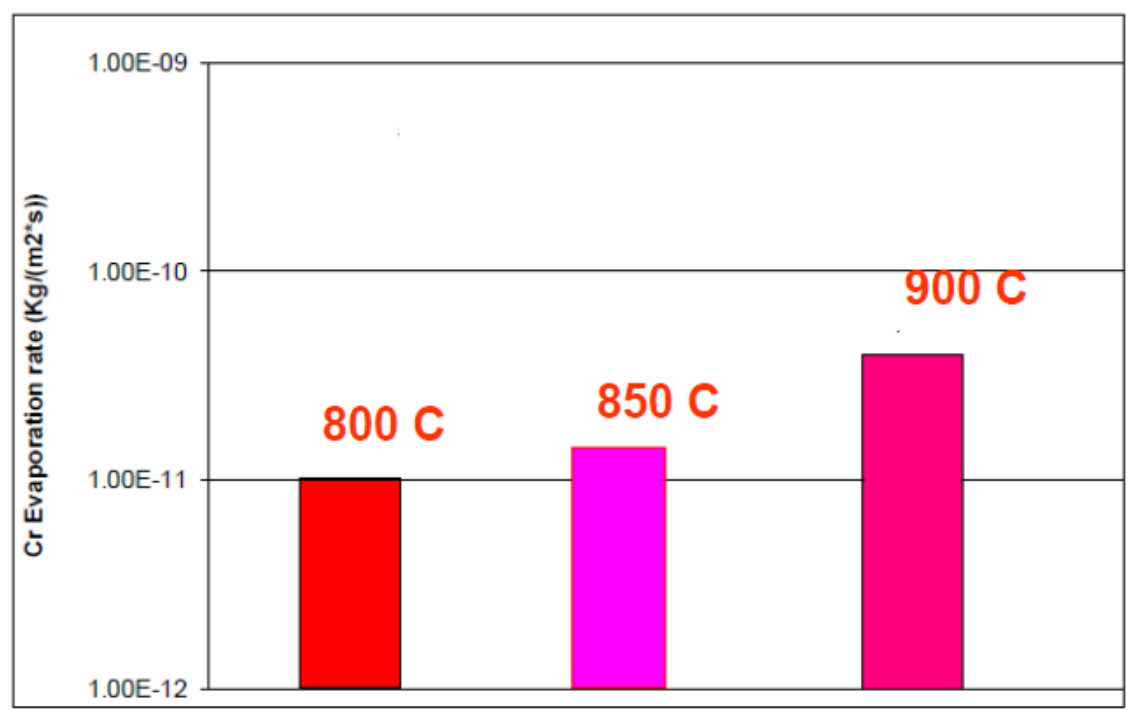

Fig. 4. Chromium evaporation rates of AFA OC4 at 800-900C in air with 3\% water vapor 9 (after UTRC/UConn final report).

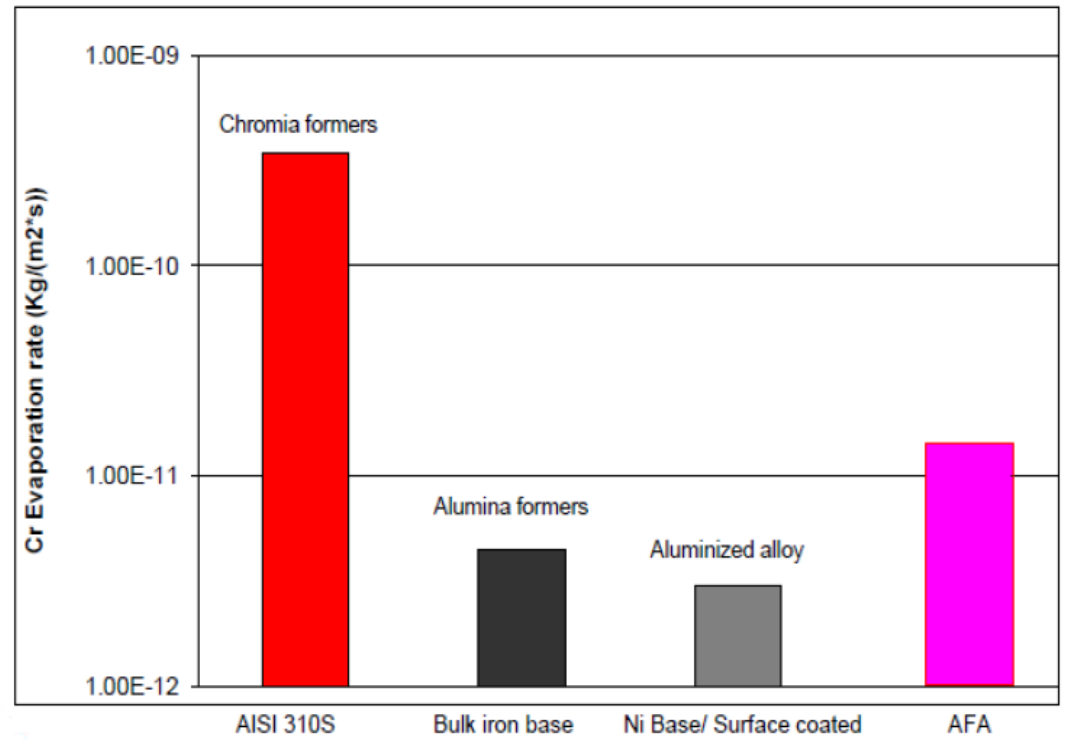

Fig. 5. Chromium evaporation rates of $\mathrm{AFA} \mathrm{OC} 4$ at $850^{\circ} \mathrm{C}$ in air with $3 \%$ water vapor relative to competing alloys (after UTRC/UConn final report).

The effort at UTRC focused on evaluating the braze behavior of $150 \mu \mathrm{m}$ (6mil) thick OC-4 foil supplied to UTRC. A number of brazing materials were identified and trial runs were completed. Figure 6 shows that the brazing produced excellent bonding and the brazing was effective in the demonstration. It was concluded that AFA alloys are a suitable candidate for SOFC balance of plant applications. 


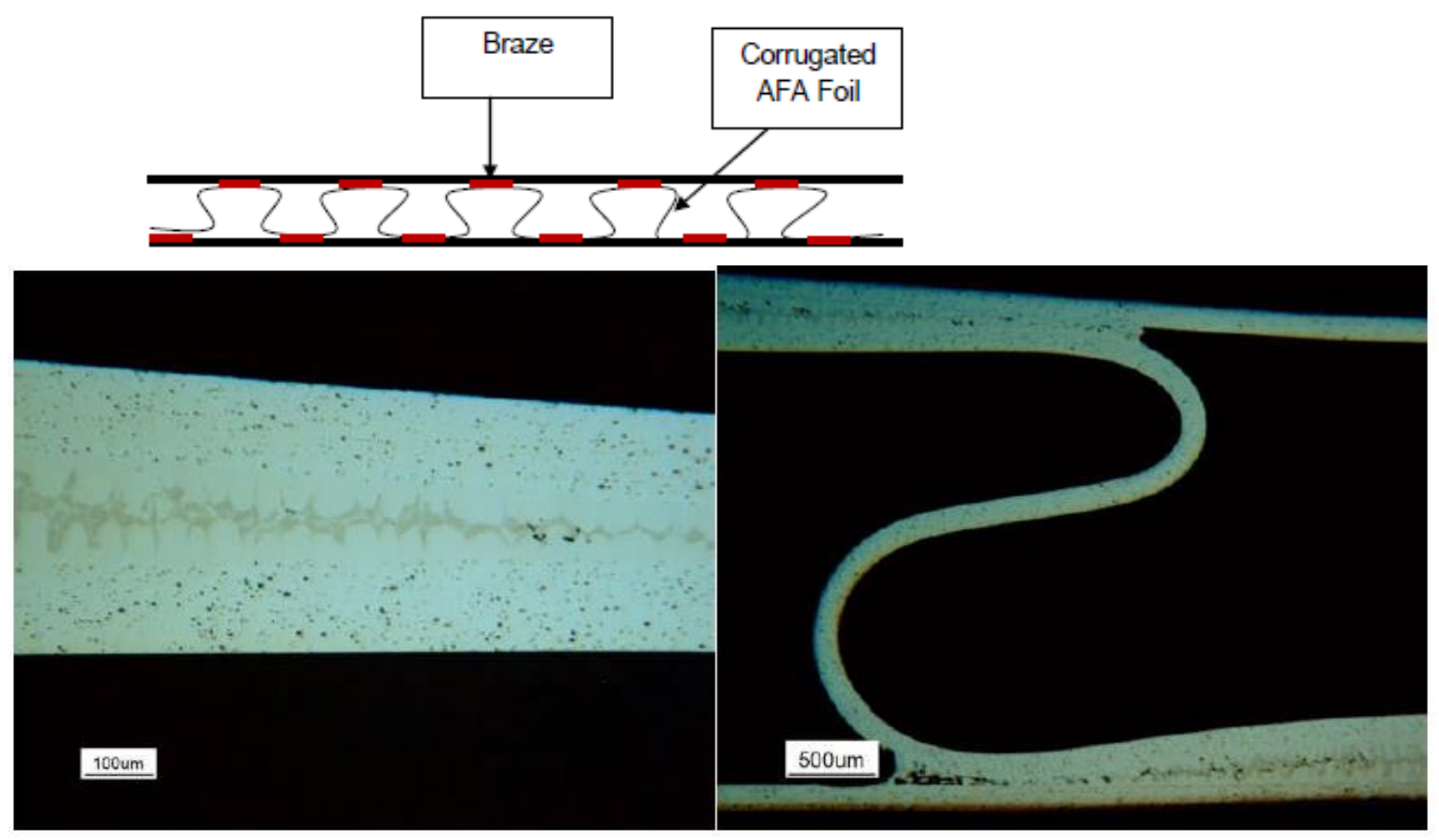

Fig. 6. Braze joint showing excellent joining of AFA foil (left) and subscale heat exchanger with folded AFA foil (right) (after UTRC/UConn final report).

\subsubsection{Solar Turbines Commercial Demonstration}

The project at Solar Turbines was performed solely on a cost-share basis. It was devoted to evaluation of AFA OC-4 alloy foil as a recuperator material for the Mercury 50 (4.6MW turbine). This collaboration was challenging because 1 ) the mercury 50 engine recuperator required $\sim 15$ " wide foil, which necessitated the use of multiple alloy post processors (described in section 3.1.1) as Carpenter does not currently produce strip material in that width range, and 2) the creep requirements in the Solar design are more stringent than those in the smaller Capstone microturbine recuperator. Folding trials of AFA OC-4 foil were successful (Fig. 7) and Solar Turbines Inc. is exposing five AFA test panels in the exhaust gas path of a Mercury 50 turbine in 2013-2014. Previously a similar procedure has been used to evaluate conventional chromia-forming AL2025Nb and 625 foils for their primary surface recuperators.

Solar Turbines technical staff also expressed concern about the AFA alloy cost and processing difficulties/supply issues encountered. As discussed in 3.1.1, the alloy post processors did not possess equipment capable of solutionizing OC-4 to $1200^{\circ} \mathrm{C}$ to achieve the optimal level of properties and processability. To address these concerns, work was initiated to evaluate alternative AFA compositions that were lower cost (lower $\mathrm{Ni}$ and $\mathrm{Nb}$ content) and amenable to lower processing temperatures. These results are discussed in the section 3.3 (Task 3) devoted to alloy development and optimization. 


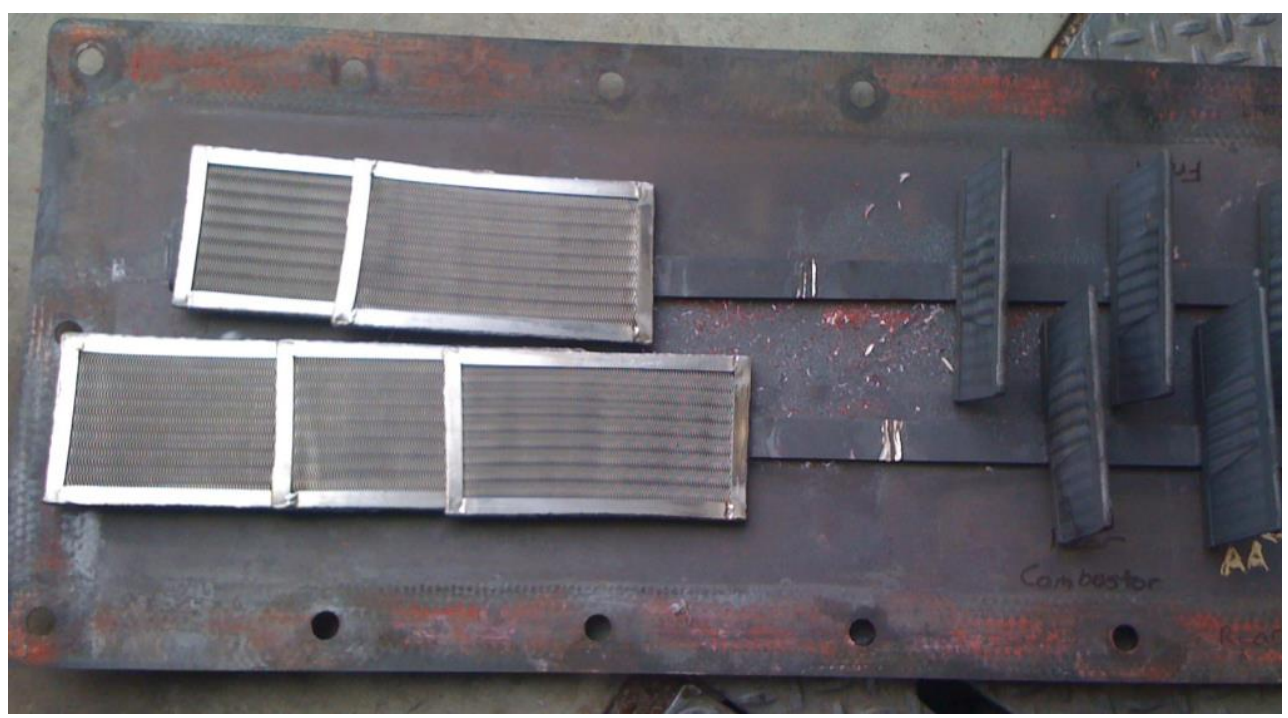

Fig. 7. Panels of folded AFA OC-4 foil to be welded into Mercury 50 turbine by Solar Turbines, Inc.

\subsubsection{Duraloy Technologies, Inc. Commercial Demonstration}

Duraloy Technologies, Inc. expressed interest in the cast versions of AFA developed under this project (section 3.4, Task 4) and pursued a trial evaluation on an in-kind effort basis. Duraloy successfully produced centrifugally cast tubes of two different cast AFA compositions. The tubes were $\sim 4.7 \mathrm{~m}$ long with a $95 \mathrm{~mm}$ OD and $\sim 16 \mathrm{~mm}$ wall thickness (Fig. 8). No problems were encountered during casting and further characterization in 2013 and 2014 of this material is planned.

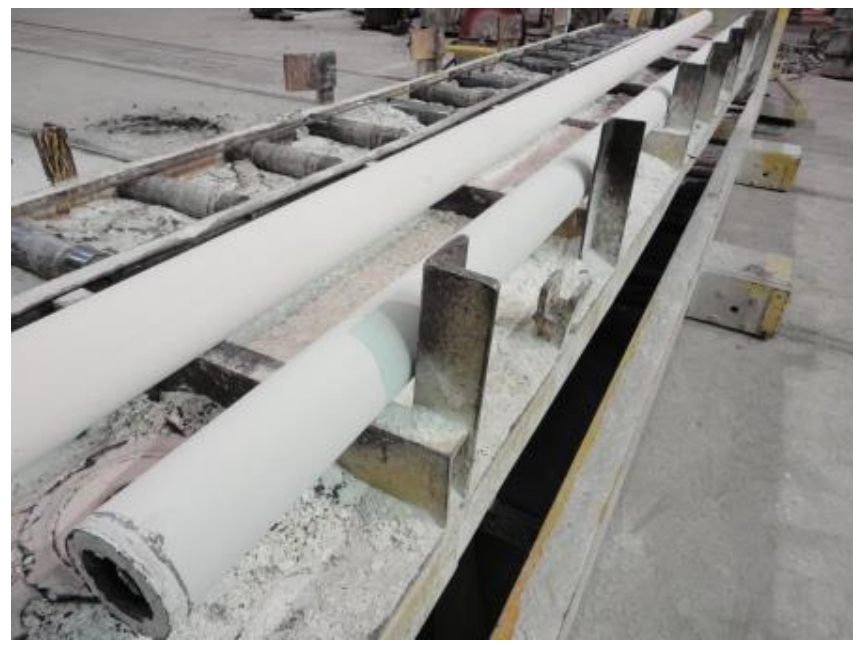

Fig. 8. Cast AFA tube made at Duraloy Technologies.

\subsubsection{Other Commercial Demonstration Activities}

AFA material for testing as widely distributed to potential industrial end users and academic institutions by both ORNL and Carpenter. These included foil material for evaluation by Cummins Turbo Technologies, field exposures by Air Products Inc., and lab scale exposures by a number of industrial and academic entities. 


\subsection{TASK 2. PROPERTY DATABASE DEVELOPMENT}

The property database development task supported creating a property database for the $\mathrm{OC} 4(\mathrm{Fe}-25 \mathrm{Ni}-$ $14 \mathrm{Cr}-3.5 \mathrm{Al}-2.5 \mathrm{Nb}-2 \mathrm{Mn}-2 \mathrm{Mo}-1 \mathrm{~W}-0.1 \mathrm{C}-0.01 \mathrm{~B}$ wt.\% base) composition of AFA steel and included subtasks on mechanical properties, environmental effects, joining, and physical properties. Based on the results of this task, a datasheet was completed and sent to Carpenter for incorporation into their product literature. The figures in this section represent the data collected for the datasheet is available to send to companies interested in the AFA properties.

\subsubsection{Subtask 1. Mechanical Properties}

Tensile, creep and fatigue testing were completed on the OC4 composition both as fabricated and after ageing, e.g. $5,000 \mathrm{~h}$ at $650^{\circ}$ or $750^{\circ} \mathrm{C}$. Figure 9 shows the $0.2 \%$ yield and the ultimate tensile stresses of OC4 as a function of temperature and compared to published data (vendor materials datasheets) for commercial stainless steel alloys $347(18 \mathrm{Cr}-11 \mathrm{Ni})$ and $120(25 \mathrm{Cr}-35 \mathrm{Ni})$. The $650^{\circ}$ and $750^{\circ} \mathrm{C}$ data points were generated at Carpenter and the other experiments were performed at ORNL.

Some creep rupture results in different product forms are shown in Figures 10 and 11 with a comparison to various commercial alloys. The creep rupture life of OC4 is greater than conventional type 347 stainless steel (SS) and comparable to advanced austenitic steels such as NF709 and Super 304H (dashed lines in Figure 10). It is not as creep resistant as Ni-base CCA617.

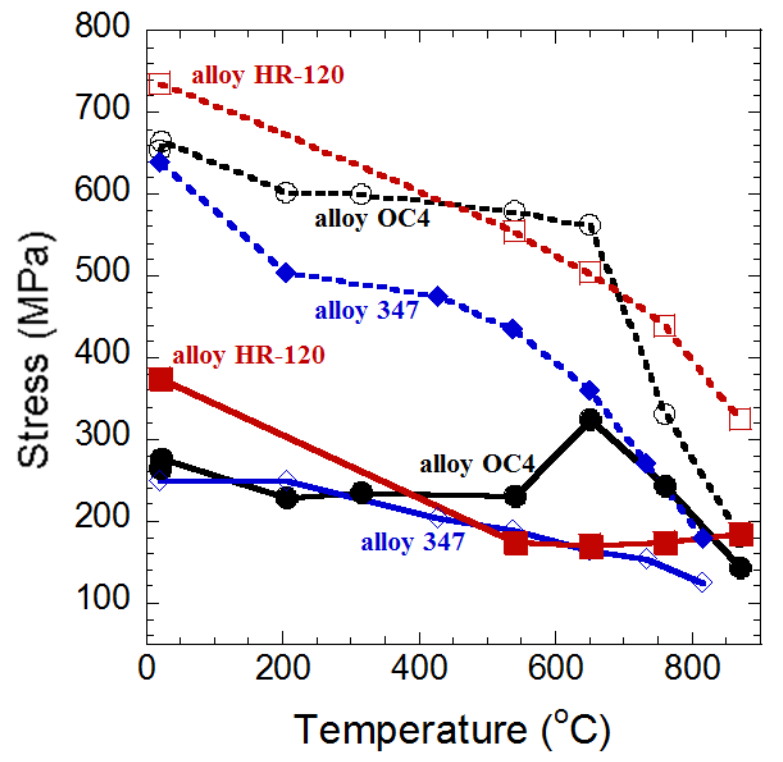

Fig. 9. Variation in $0.2 \%$ yield (solid lines) and tensile strength (broken lines) with temperature for AFA composition OC4 compared to two commercial alloys. 


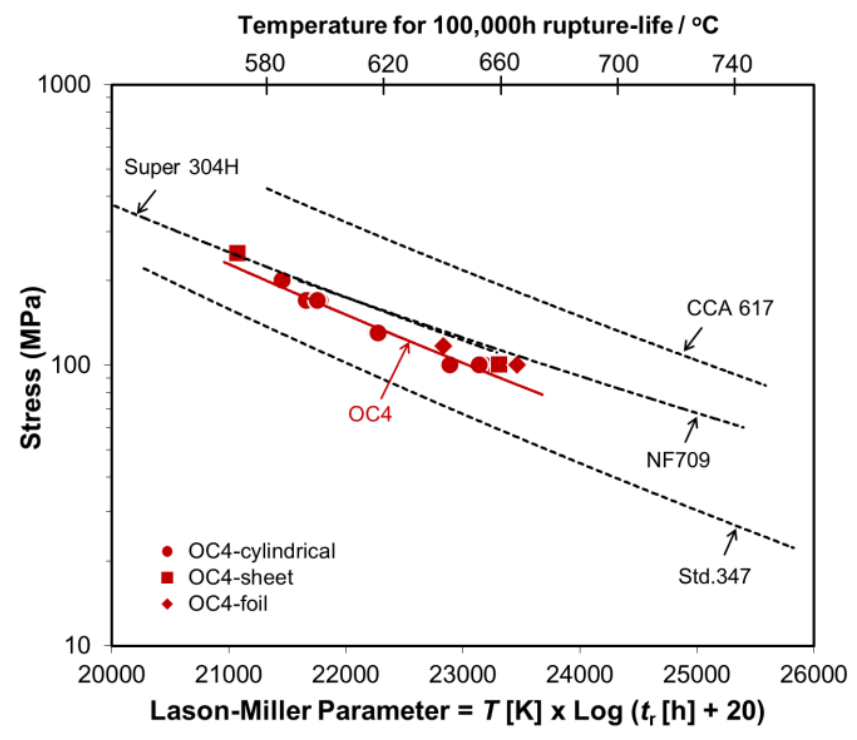

Fig. 10. Larson Miller Parameter plot of alloy $\mathrm{OC} 4$ creep rupture data plotted as a function of stress along with some benchmark commercial high temperature austenitic stainless steels (347, Super 304H and NF709) and a Ni-base alloy (CCA617).

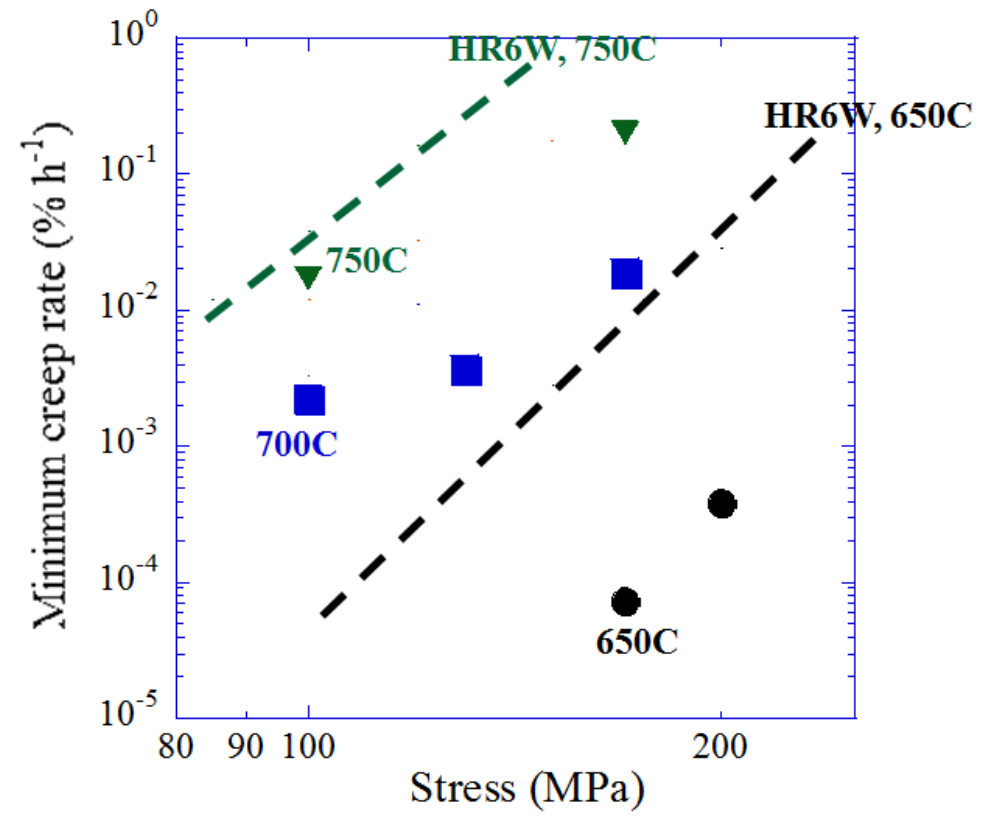

Fig. 11. Minimum creep rate of AFA alloy $\mathrm{OC} 4$ plotted as a function of stress at $650^{\circ} \mathrm{C}$ (circle), $700^{\circ} \mathrm{C}$ (square), and $750^{\circ} \mathrm{C}$ (triangle) compared to alloy $\mathrm{HR6W}$ (lines).

Post-test characterization of the fracture surface showed homogeneous nucleation of fine B2 ((Fe,Ni) $\mathrm{Al})$, Laves $\left(\mathrm{Fe}_{2} \mathrm{Mo}\right)$ and $\mathrm{MC}(\mathrm{NbC})$ precipitates with some $\sigma$-phase grain boundary precipitates. The observation of small $(1-20 \mu \mathrm{m})$ voids on the fracture surface suggested void nucleation and growth controls creep life. Microstructure examination also indicated that the creep strengthening mechanism of OC4 may be different at $650^{\circ} \mathrm{C}$ then at $\geq 700^{\circ} \mathrm{C}$. A coherent intermetallic $\mathrm{L}_{2}-\mathrm{Ni} 3 \mathrm{Al}\left(\gamma^{\prime}\right)$ phase $\left(\sim 20 \mathrm{~nm}\right.$ average size) precipitated uniformly in the matrix at $<700^{\circ} \mathrm{C}$, which is believed to be the main 
creep-strengthening phase at $650^{\circ} \mathrm{C}$. However, these $\gamma^{\prime}$-precipitates were observed to dissolve in the matrix after $\sim 3000 \mathrm{~h}$ of creep testing at $650^{\circ} \mathrm{C}$ suggesting that it is a metastable phase in alloy OC-4. Dissolution of the $\gamma^{\prime}$ precipitates would be expected to significantly degrade the creep resistance of OC4. Above $700^{\circ} \mathrm{C}, \mathrm{MC}$ carbides and $\mathrm{Fe}_{2} \mathrm{Mo}$ (Laves phase) are the primary strengthening phases. For example, at $650^{\circ} \mathrm{C}$ the minimum creep rate exhibited by alloy OC4 is $\sim 2$ orders of magnitude lower than that of alloy $\mathrm{HR} 6 \mathrm{~W}(\mathrm{Fe}-23 \mathrm{Cr}-45 \mathrm{Ni}-7 \mathrm{~W}-0.1 \mathrm{C})$, whereas at $750^{\circ} \mathrm{C}$ it is comparable to HR6W, Figure 10.

Fatigue results are summarized in Figure 12. Figure 12a shows the number of cycles to failure at room temperature with two different strain rates compared to commercial stainless steel types 316 and 347 . The $\sim 15 \%$ decrease in OC4 life with increasing strain rate from 0.5 to $2 \mathrm{~s}^{-1}$ was attributed to earlier macro-crack initiation at the faster strain rate. During ageing, a substantial increase in the room temperature yield and ultimate tensile stress and decrease in ductility was observed due to ageing. However, the decrease in ductility did not translate into a significant reduction in the low cycle fatigue life, Figure 12b.
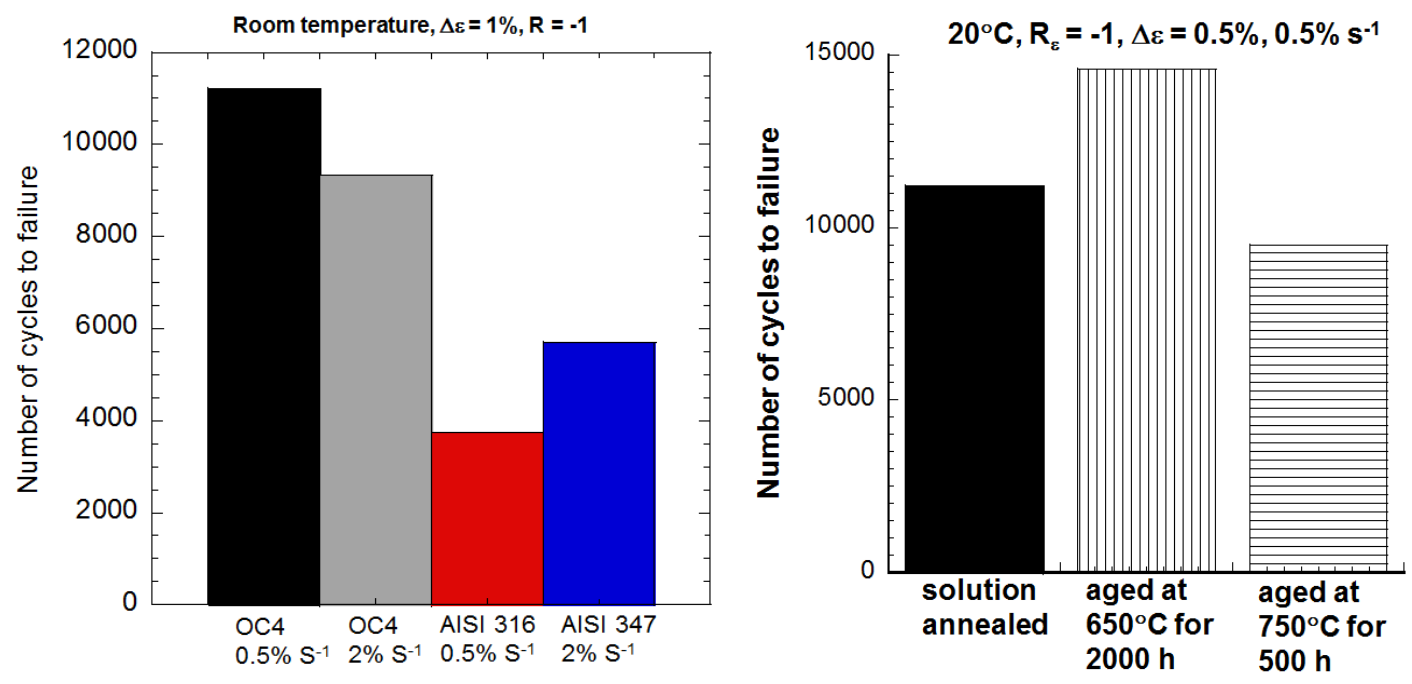

Fig. 12. Room temperature low cycle fatigue data: (a) cycles to failure for AFA alloy OC4 compared to type 316 and 347 stainless steels; the strain rates were either 0.5 or $2 \mathrm{~s}-1$, as noted, with a total strain of $1 \%$ and (b) effect of solution annealing at $650^{\circ}$ and $750^{\circ} \mathrm{C}$ on lifetime.

\subsubsection{Subtask 2. Environmental Effects}

Figure 13 gives a general overview of the improved oxidation for AFA compared to conventional chromia-forming stainless steels. The thin, alumina scale for AFA contrasts with the thicker oxides formed on alloy 120 after $10,000 \mathrm{~h}$ or the much thicker oxide formed on cast CF8C (similar to type $347 \mathrm{SS}$ ) after only 5,000h. Specific results for several different sets of experiments are shown in Figures 14-16. 

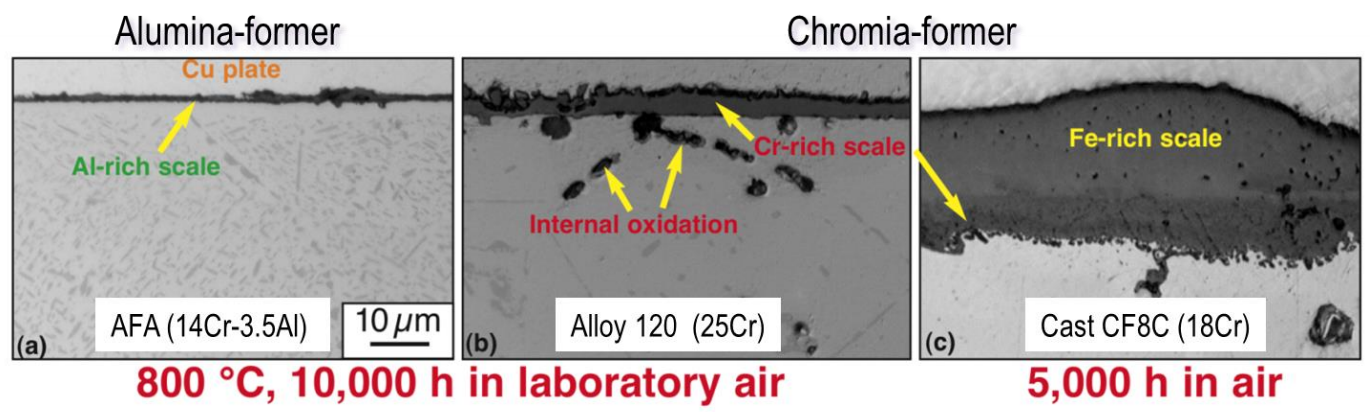

Fig. 13. Light microscopy of polished cross-sections after long term exposures in air at $800^{\circ} \mathrm{C}(\mathrm{a})$ AFA after 10,000h, (b) alloy 120 after 10,000h and (c) cast CF8C after only 5,000h.

In general, long-term experiments were conducted on OC4 to compare its environmental resistance to other relevant commercial alloys. For example, results from $17 \mathrm{bar}$ steam at $800^{\circ} \mathrm{C}$ are shown in Figure 14. The mass gain for several OC4 coupons is shown (OC4 specimens stopped after 1, 4, 5 and 10kh), which is similar to a ferritic alumina-forming alloy composition (FeCrAlY) and a new Ni-base commercial alumina-forming alloy (224). Due to the formation of a slower-growing alumina scale, the mass gain of OC4 is much lower than a conventional Ni-base chromia-forming alloy (740) or other chromia-forming alloys HR6W and 120. The mass gains in steam are generally higher than those observed in laboratory air as $\mathrm{H}_{2} \mathrm{O}$ is known to accelerate the rate of oxidation.

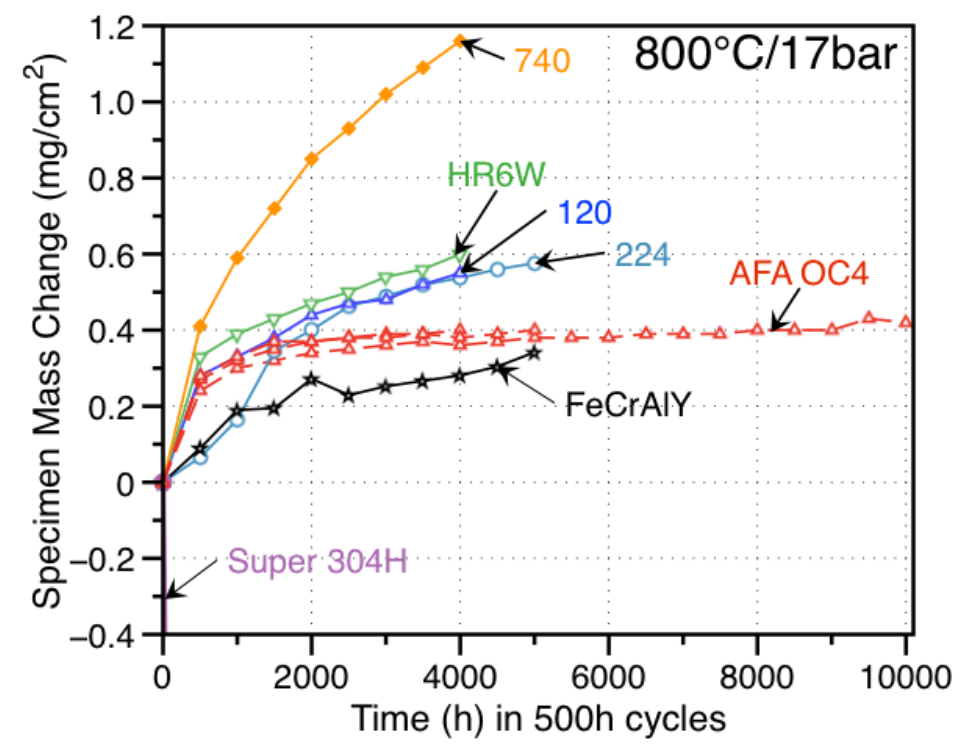

Fig. 14. Mass gains for coupons exposed in $500 \mathrm{~h}$ cycles at $800^{\circ} \mathrm{C}$ in $17 \mathrm{bar}$ steam.

OC4 was compared to alloys 120 and 347 in three different environments, Figure 15. In dry air at $700^{\circ} \mathrm{C}$, the mass gain for AFA was much lower than for the chromia-scale forming $347 \mathrm{H}$ stainless steel after 5,000h. However, the more significant benefit can be observed in wet air or $17 \mathrm{bar}$ steam, where major mass losses were observed for $347 \mathrm{H}$ and the specimens were stopped after only 1,000$1,500 \mathrm{~h}$ exposures. HR120 also showed similar good oxidation resistance (i.e. low mass changes) in these environments but contains higher $\mathrm{Ni}(35 \%)$ and $\mathrm{Cr}(25 \%)$ contents than OC4. The slight mass loss for $\mathrm{HR} 120$ after $5,000 \mathrm{~h}$ at $700^{\circ} \mathrm{C}$ in wet air is due to the evaporation of the volatile $\mathrm{CrO}_{2}\left(\mathrm{OH}_{2}\right)$ reaction product, which leads to more rapid degradation of thin-walled components. The alumina scale formed on AFA is resistant to this form of attack with only a small mass gain in each case. 


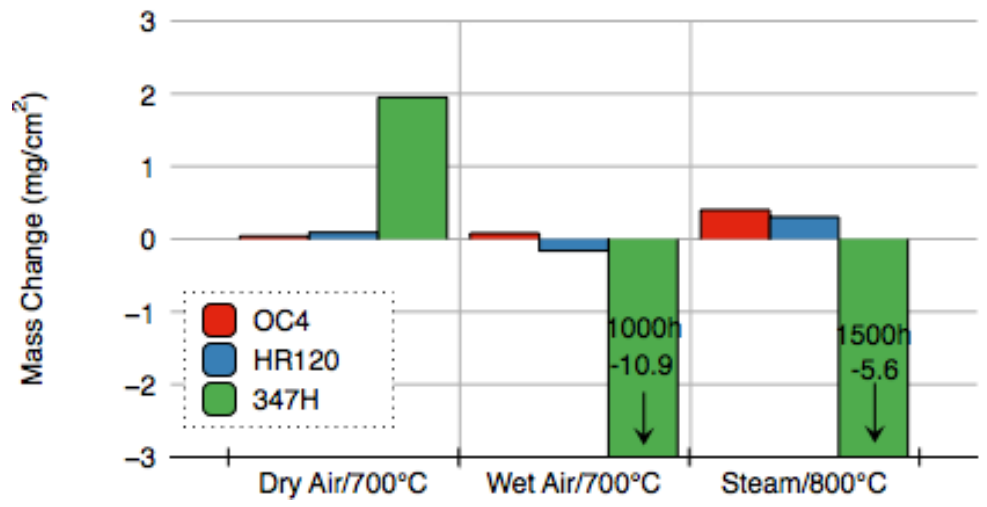

Fig. 15. Specimen mass change for AFA OC4 compared to HR120 and $347 \mathrm{H}$ in three different environments for $5,000 \mathrm{~h}$. The $347 \mathrm{H}$ specimens were stopped at shorter times because of the severe attack observed.

Figure 16 summarizes some of the results from metal dusting experiments used to evaluate the performance of $\mathrm{OC} 4$ in the presence of low $\mathrm{O}$ and high $\mathrm{C}$ activities found in the chemical process industry. In practice, water vapor is added to these environments to inhibit metal dusting and these results illustrate the benefit of adding water vapor for some materials. Simply adding H2O lowers the carbon activity, so these experiments maintained a $\mathrm{C}$ activity of 10 by increasing the total pressure. Grade $122(\mathrm{Fe}-10 \mathrm{Cr})$ and $347 \mathrm{H}$ stainless steel were more strongly attacked without $\mathrm{H}_{2} \mathrm{O}$ showing mass losses due to pitting. However, both alloys were protective with $28 \% \mathrm{H}_{2} \mathrm{O}$, as were the more heavily alloyed materials except $\mathrm{NiAl}$, which was only protective with $0-10 \% \mathrm{H}_{2} \mathrm{O}$. For one condition, the specimens ran a total of $5,000 \mathrm{~h}(10,500$-h cycles) to show the effect of longer exposures on these materials. Metal dusting can occur after an incubation period where the alloy shows protective behavior, thus, there is a strong value in conducting longer experiments. In this case, none of the alloys exposed for longer times showed a significant increase in mass between 500h and 5,000h, Figure 16.

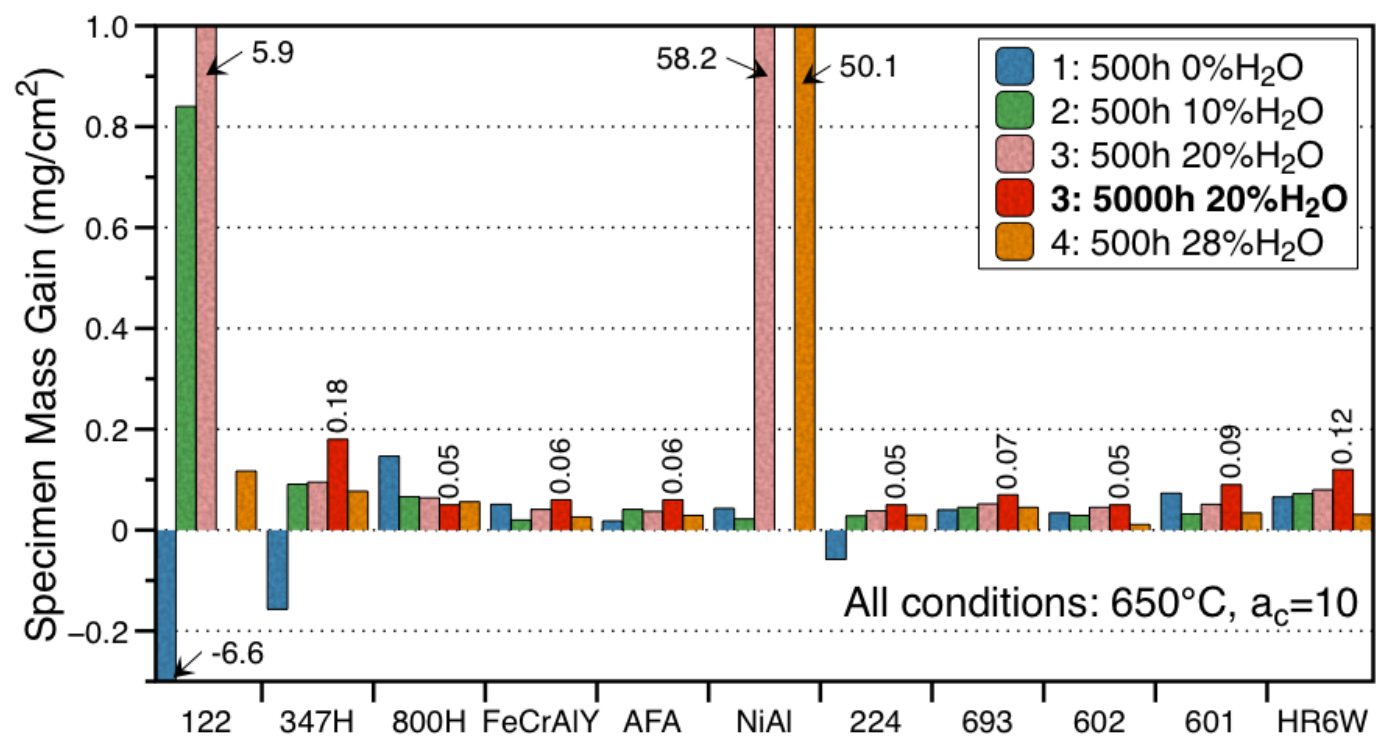

Fig. 16. Mass change for different alloys compared to AFA OC4 after 500h exposures at four different conditions with increasing $\mathrm{H} 2 \mathrm{O}$ contents. The pressure was increased from 1 to $16 \mathrm{~atm}$ in the fourth condition to maintain a $\mathbf{C}$ activity of $\mathbf{1 0}$. 


\subsubsection{Subtask 3. Joining}

This task was designed to assess OC4 joining issues that the industrial partners may encounter as well as make standardized evaluations of different commercial joining processes to determine best practices and determine the effect of the weld on other properties. The major task was welding $10 \mathrm{~mm}$ thick plates of OC4 using filler wire (fabricated by Stoody Co.) of the same nominal composition. The automated gas tungsten arc weld was radiographed to ensure it was free of defects and then sectioned for tensile, bend, and creep tests. Figure 17 shows a portion of the welded specimen that was sectioned. Figure 18 shows that welded OC4 was similar in strength at $650^{\circ} \mathrm{C}(140,170$ and 200 $\mathrm{MPa})$ and $700^{\circ} \mathrm{C}(100 \mathrm{MPa})$ as the base material with only a slight weld reduction factor.

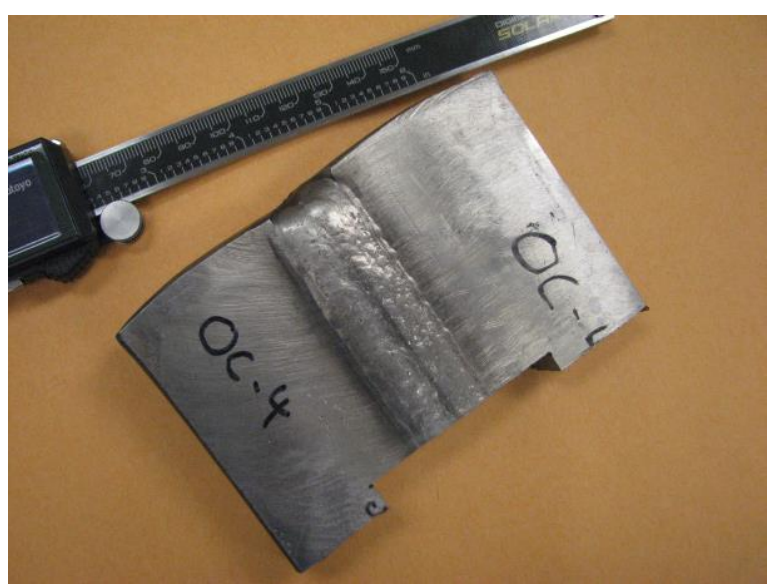

Fig. 17. Welded 10mm OC4 plate being machined into creep specimens.

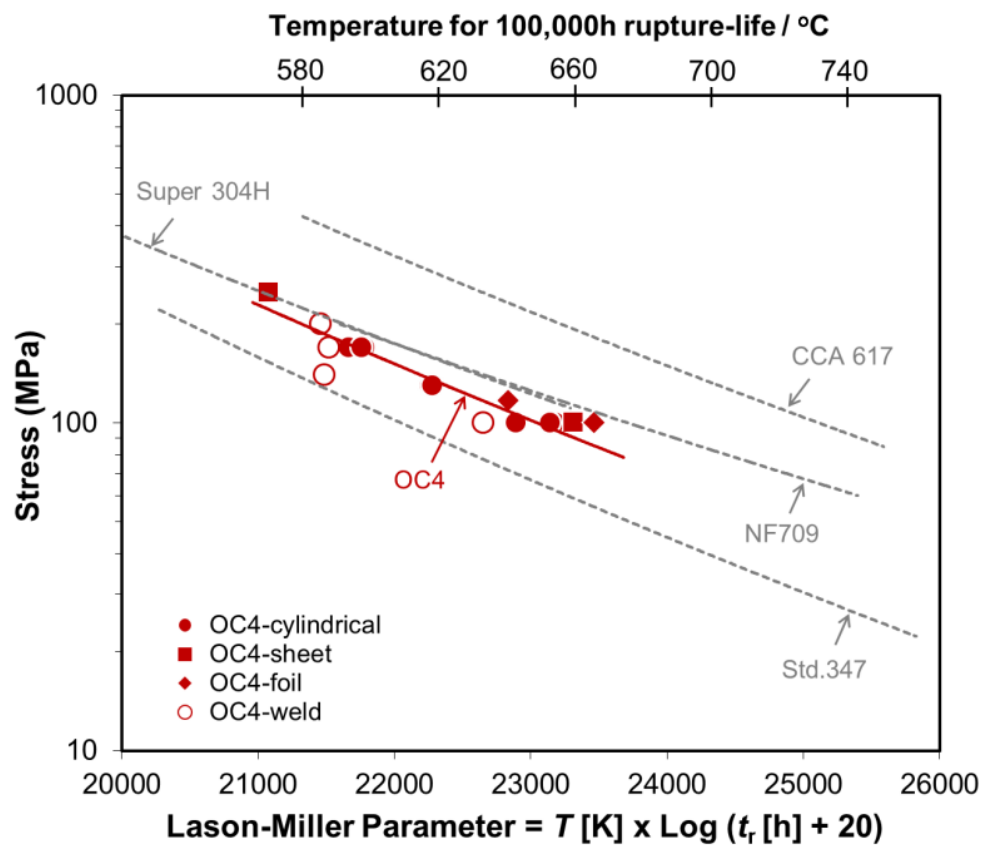

Fig. 18. Applied stress plotted against the Larson-Miller Parameter for creep tests of OC4 base metal and cross-weld specimens. 
As an example of the work with companies, a trial joining of foil material was conducted at Flexial Welded Bellows (Cookeville, TN). Flexial stamped blanks of OC4 4.2mil thick foil using their standard procedure, Figure 19. The corrugated bellows pieces were then test welded. Due to the surface oxide on the foil, the welding was only partially successful with some cracks developing. Improved surface finish of AFA foil remains a long-term goal. Brazing trials also were conducted on 13 mil OC4 sheet. T-joints of four different braze materials were made. Brazes BAu-4 and Ticusil showed good wetting.

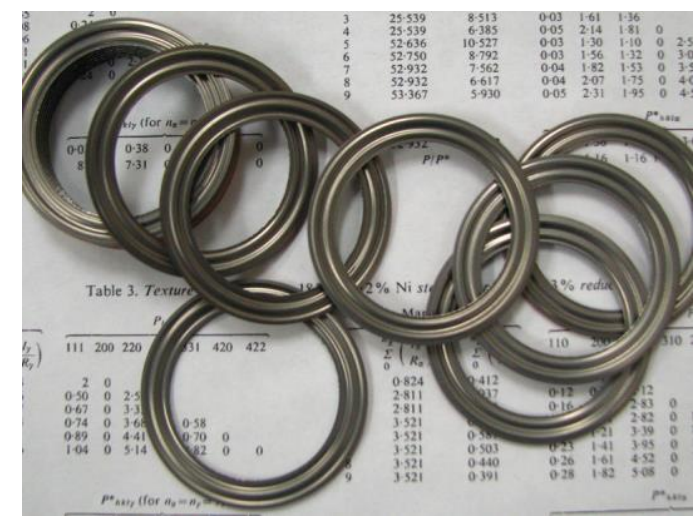

Fig. 19. Stamped bellows segments made from AFA foil.

\subsubsection{Subtask 4. Physical Properties}

The measurement of physical properties such as thermal expansion, thermal conductivity, electrical resistance and Young's modulus as a function of temperature had not been previously generated and were needed for the AFA materials database. Figures 20-22 summarize the data generated in this task. Figure 20 shows that the thermal expansion and thermal conductivity for OC4 are similar to other austenitic steels. Mean expansions typically increase slightly with temperature and the deviations for OC4 likely represent minor phase transformations. The other physical properties were similar to other commercial alloys, except for the electrical resistivity, which was similar to 347 stainless steel but not the higher alloyed materials such as alloys $120,800 \mathrm{H}$ and Ni-base alloy 230, Figure $21 \mathrm{a}$.
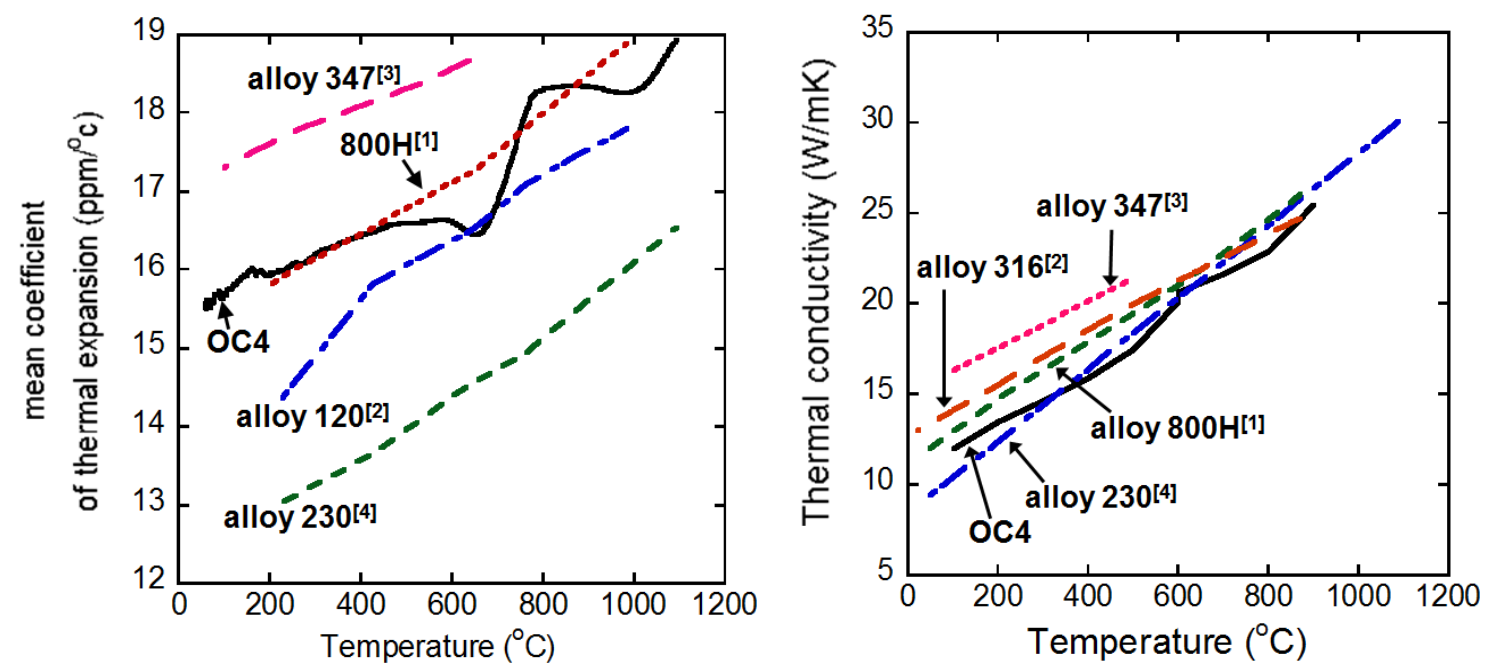

Fig. 20. (a) Mean thermal expansion and (b) thermal conductivity of $\mathrm{OC} 4$ and other alloys as a function of temperature. 

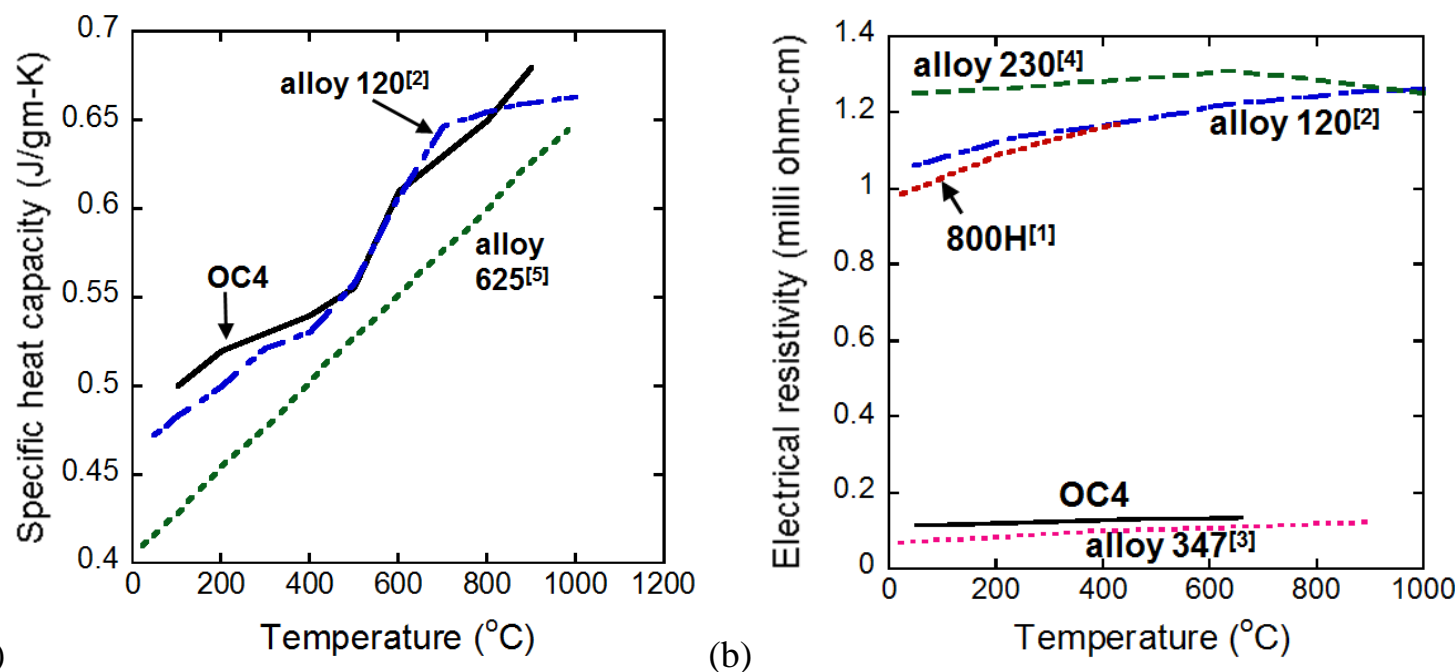

Fig. 21. (a) Specific heat capacity and (b) electrical resistivity of OC4 and other alloys as a function of temperature.
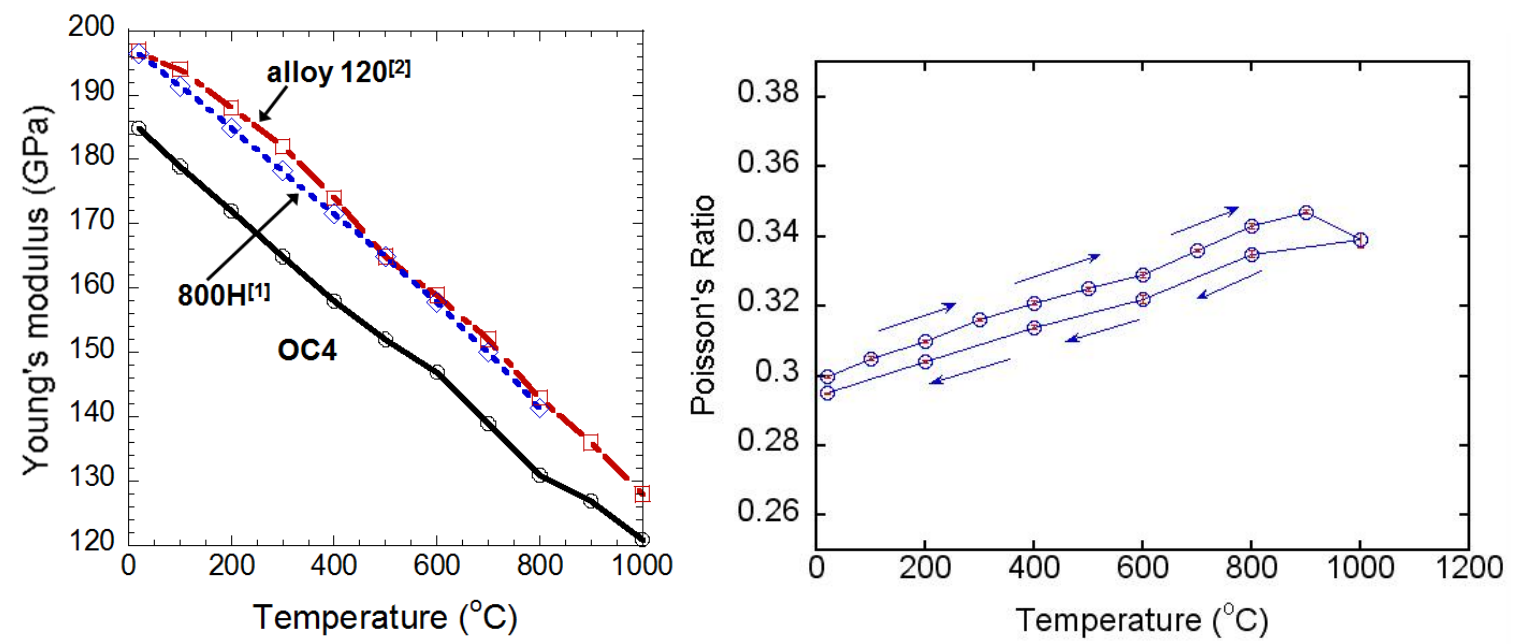

Fig. 22. Variation in (a) Young's modulus and (b) Poisson's ratio for $\mathrm{OC} 4$ as a function of temperature.

\subsubsection{Creep and Oxidation Resistance of the Commercial OC4 Foil Batches}

Separate from the OC4 datasheet work, a task was added to evaluate the creep and oxidation resistance of the commercial batches of OC4 composition foil material (80, 106 and $150 \mu \mathrm{m}$ thickness). The thinner foils were fabricated for two different turbine recuperator applications $(80 \mu \mathrm{m}$ for Capstone; $106 \mu \mathrm{m}$ for Solar Turbines) and the thickest foil for another heat exchanger application specified by another potential industrial partner. Example microstructures are shown in Figure 23. No preferential grain orientation was observed, and the average grain size was estimated to be $\sim 20 \mu \mathrm{m}$ for the $80 \mu \mathrm{m}$ foil labeled A and $\sim 35 \mu \mathrm{m}$ for the $150 \mu \mathrm{m}$ foil labeled B, but with a significant population of grains over $60 \mu \mathrm{m}$ in diameter. (Such a wide range of grain sizes was not typical in commercial 347 or alloy 120 foils.) Alignment of carbides along the rolling direction was observed in the thicker foil. The main difference between the two foils was the presence of a $10 \mu \mathrm{m}$ affected layer at the surface of the $150 \mu \mathrm{m}$ foil, filled with nitride precipitates (inset in Figure 23b). 


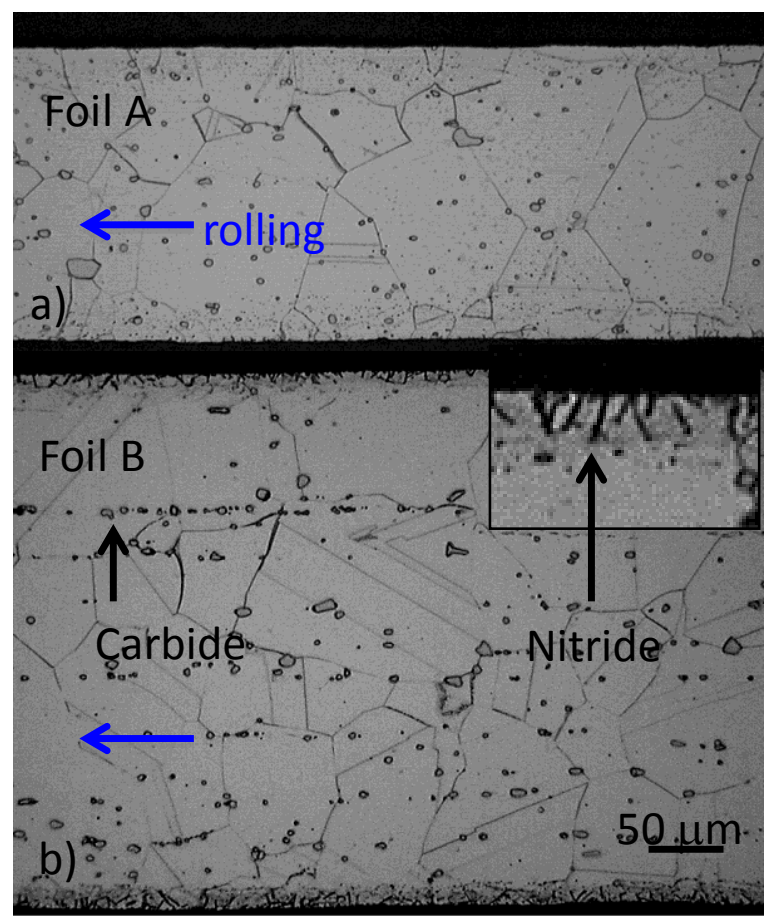

Fig. 23. Light microscopy of the longitudinal cross section of the AFA foils (a) $80 \mu \mathrm{m}$ " $A$ " and (b) $150 \mu \mathrm{m}$ "B".

Oxidation tests were conducted in four different temperatures, $650^{\circ}-800^{\circ} \mathrm{C}$ in "wet" air with $10 \% \mathrm{H}_{2} \mathrm{O}$. A summary of the observed mass gains after $4,000 \mathrm{~h}$ exposures is shown in Figure 24. The initial batches of 80 and $106 \mathrm{~mm}$ foil were too narrowed to make recuperator air cells and second batches were made of the correct width. The low mass gains in these experiments, increasing with exposure temperature as expected, are comparable among the various batches except for $800^{\circ} \mathrm{C}$ where the widest variation in behavior was observed. The starting foil surface finish may be more important at this temperature. Specimens of the 80 and $150 \mu \mathrm{m}$ thick foils were stopped at each temperature after $1,000 \mathrm{~h}$ exposures and cross-sections of the thin reaction product are shown in Figure 25. Occasional oxide nodules rich in $\mathrm{Nb}$ and $\mathrm{Fe}$ were observed in both materials. The nitride rich layer found on the surface of the $150 \mu \mathrm{m}$ thick foil (Figure 23b) did not appear to have a detrimental effect on oxidation resistance. The cleaner surface finish on the $2^{\text {nd }}$ batch of $80 \mu \mathrm{m}$ foil resulted in the highest mass gain at $800^{\circ} \mathrm{C}$.

Figure 26 shows the creep testing results at $750^{\circ} \mathrm{C}$ and $100 \mathrm{MPa}$, standard conditions used to rank foil performance. The creep rates for the $150 \mu \mathrm{m}$ foil were unexpectedly high, with a rupture time four times lower than previous batches of material. The $2^{\text {nd }}$ batch of $80 \mu \mathrm{m}$ foil was significantly better and showed creep lives similar to the first batches of foil. The low creep rupture life for a $106 \mu \mathrm{m}$ foil specimen (112h) was confirmed with a second test. The low creep strength for this batch is attributed to a final anneal that was likely $\sim 1050^{\circ} \mathrm{C}$ rather than $1200^{\circ} \mathrm{C}$ used in laboratory anneals. The higher temperature is difficult to achieve in commercial continuous annealing lines and future foil alloy development is focused on compositions that require an $1100^{\circ} \mathrm{C}$ final anneal. 


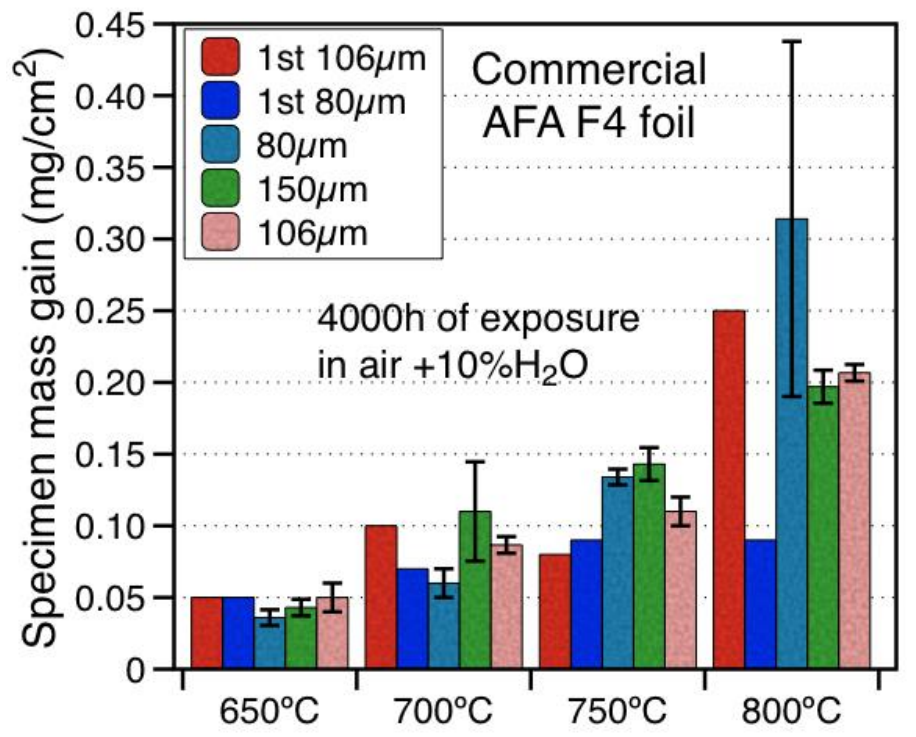

Fig. 24. Specimen mass change of commercial OC4 foil coupons after 4,000h exposures at each temperature in wet air. The ticks on the bars show a standard deviation for multiple specimens.

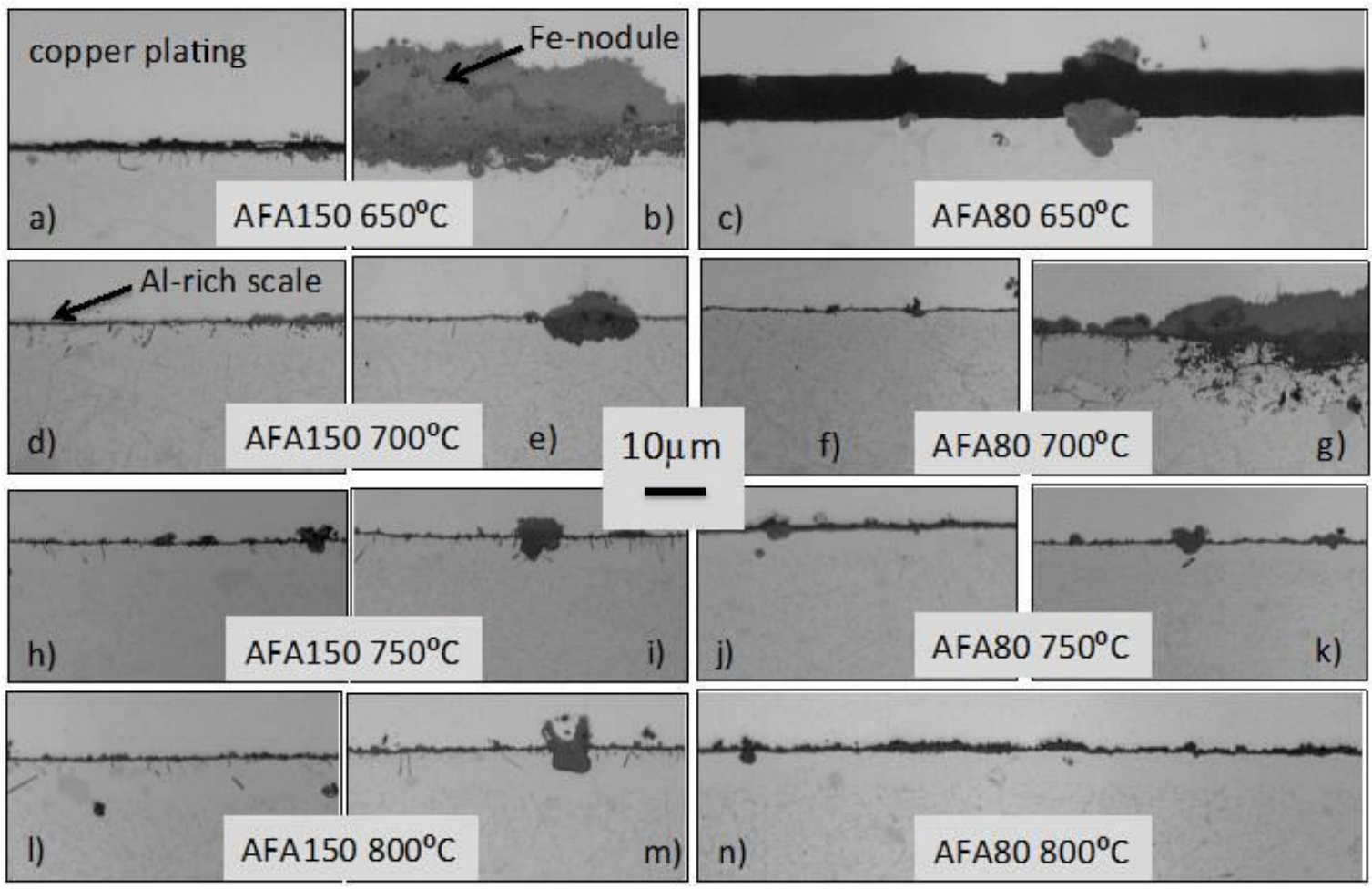

Fig. 25. Light microscopy images of polished cross sections of $\mathrm{OC} 4$ foils exposed for $1000 \mathrm{~h}$ in air $+10 \% \mathrm{H} 2 \mathrm{O}$, (a,b) $150 \mu \mathrm{m}, 650^{\circ} \mathrm{C}$, (c) $80 \mu \mathrm{m}, 650^{\circ} \mathrm{C}$, (d,e) $150 \mu \mathrm{m}, 700^{\circ} \mathrm{C}$, (f,g) $80 \mu \mathrm{m}, 700^{\circ} \mathrm{C}$, (h,i) $150 \mu \mathrm{m}$, $750^{\circ} \mathrm{C},(\mathrm{j}, \mathrm{k}) 80 \mu \mathrm{m}, 7^{\circ} 0^{\circ} \mathrm{C},(\mathrm{l}, \mathrm{m}) 150 \mu \mathrm{m}, 800^{\circ} \mathrm{C},(\mathrm{n}) 80 \mu \mathrm{m}, 8^{\circ} 0^{\circ} \mathrm{C}$. Mainly thin, protective Al-rich oxides are found at each temperature. 


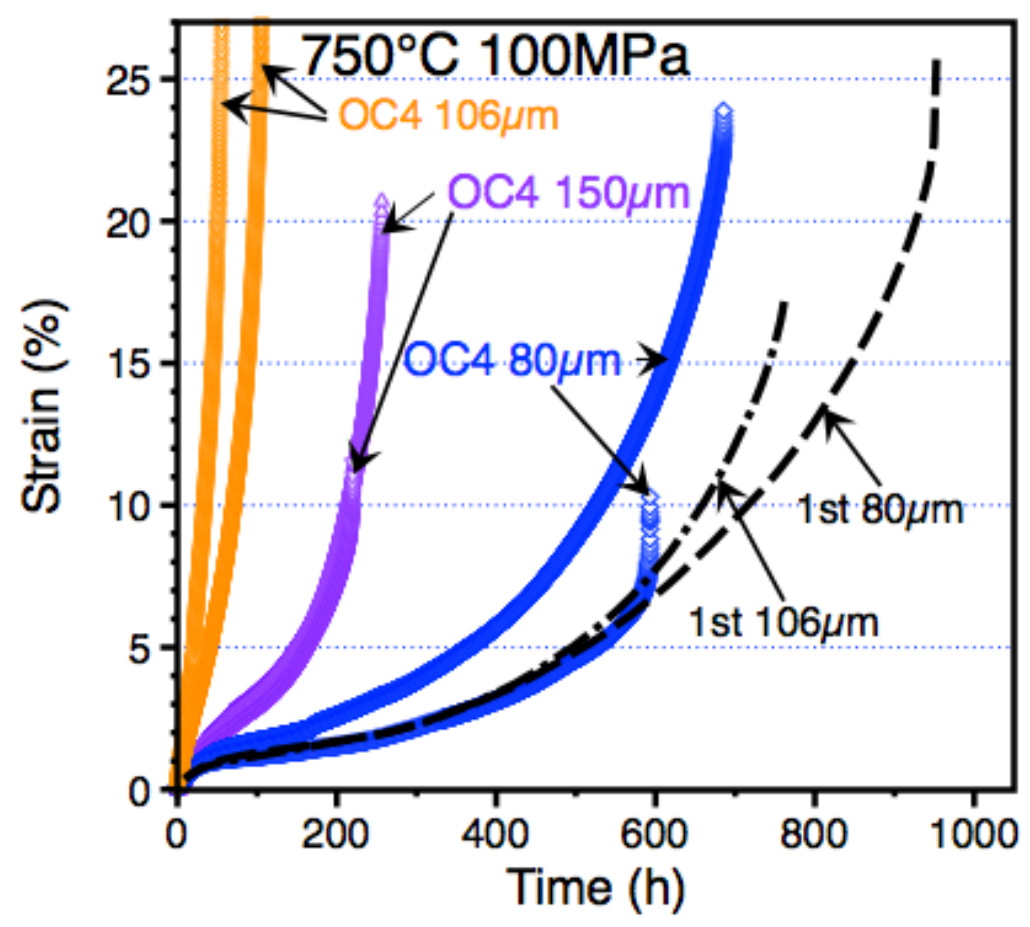

Fig. 26. Creep curves at $750^{\circ} \mathrm{C}$ with an applied stress of $100 \mathrm{MPa}$ for the three new commercial batches of AFA foil. For comparison, older batches are shown.

Finally, pieces of folded OC4 and Haynes International alloy 120 (i.e. H120) foils were received from Capstone Turbine Corp. (Figures 27a and 27b) and sectioned for analysis. The main difference between the two specimens was the presence of smaller grains for the alloy 120 foil, Figures $27 \mathrm{c}$ and 27d. The measured hardness values were higher for both folded foils compared to the as-received material, Table 2. Measured hardness values from the polished sections (longitudinal) were similar for both alloys. However, when the hardness was measured in the top of the cross-section (with the highest curvature), alloy 120 foil had a higher hardness.
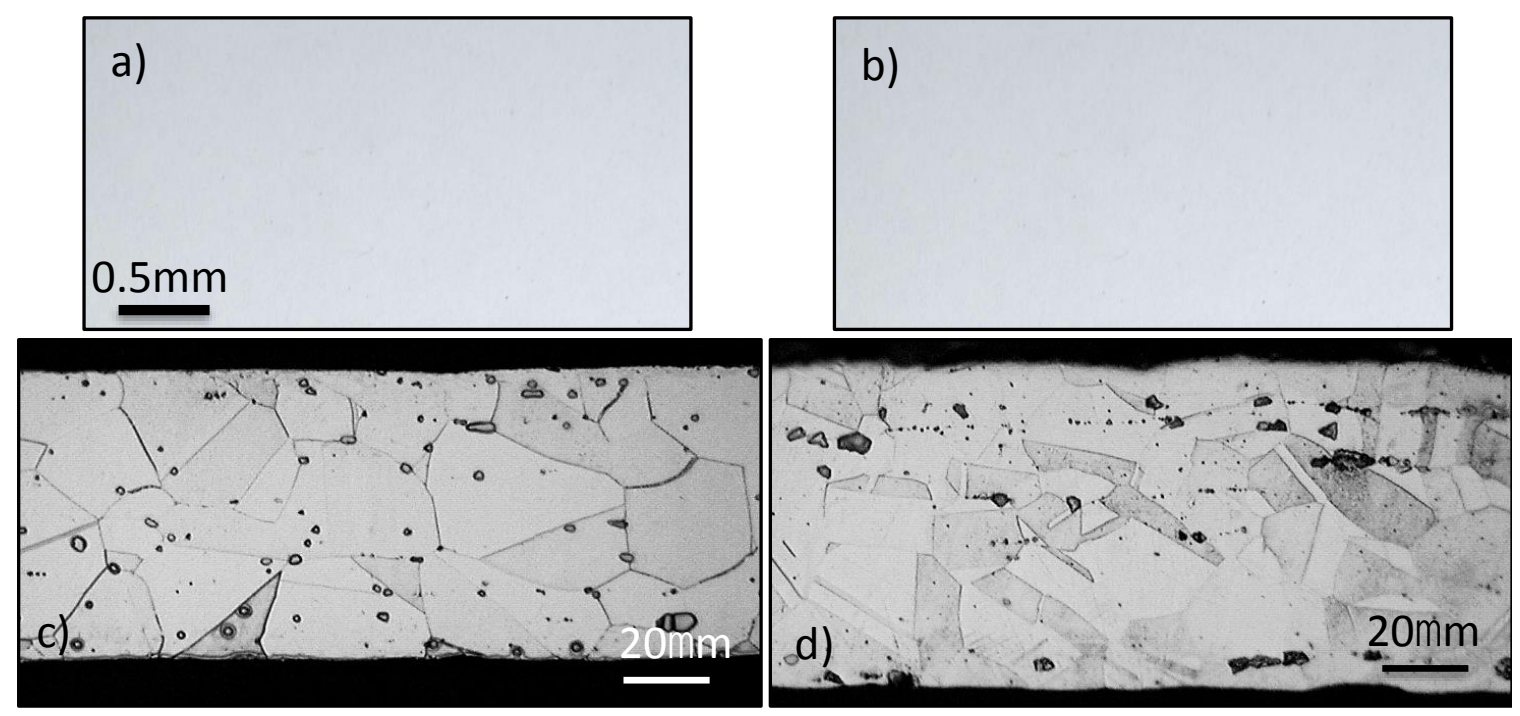

Fig. 27. Sections of foil recuperators in macro and light microscopy of polished cross-sections (a,c) 80um AFA OC4 foil and (b,d) alloy 120 foil. 
Table 2. Hardness values for the as received and recuperator AFA and H120 foils

\begin{tabular}{|c|c|c|c|c|c|c}
\hline \multicolumn{3}{|c|}{ As received } & \multicolumn{4}{c}{ Recuperator } \\
\hline \multicolumn{3}{|c|}{ longitudinal } & \multicolumn{2}{c}{ longitudinal } & \multicolumn{2}{c}{ from the top } \\
\hline AFA80 & AFA150 & H120 & AFA & H120 & AFA & H120 \\
\hline 180 & 176 & 180 & 288 & 291 & 285 & 375 \\
\hline
\end{tabular}

\subsection{TASK 3. ALLOY DEVELOPMENT AND OPTIMIZATION}

The purpose of this task was to investigate modified AFA compositions that (1) improve on the currently observed properties, (2) reduce alloy cost, or (3) address manufacturing issues that may arise during scale up to commercial production. Preliminary studies of the baseline AFA OC4 composition indicated a promising combination of creep and oxidation resistance, although this composition with its higher $\mathrm{Nb}$ and $\mathrm{Al}$ levels favors optimized oxidation over optimized creep resistance. Computational thermodynamic assessment and aging studies revealed a tendency towards formation of a small volume fraction of brittle $\sigma$ phase formation below $\sim 700-750^{\circ} \mathrm{C}$, Figure 28. Based on computational analysis, a series of alloys with variations in $\mathrm{C}, \mathrm{Mo}, \mathrm{Nb}, \mathrm{W}$ content were assessed, Table 3.

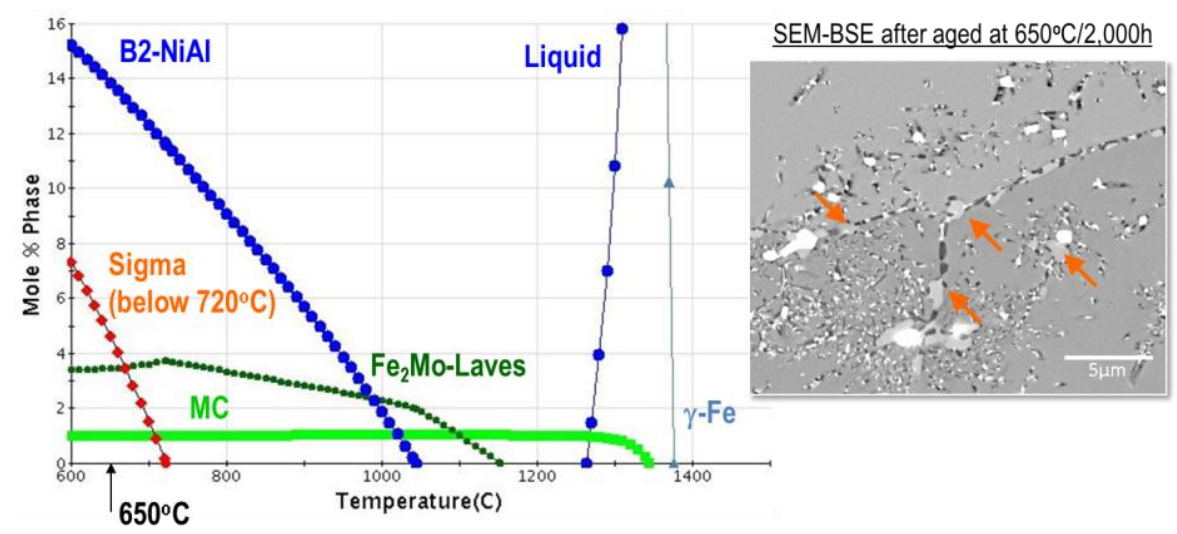

Fig. 28. Computational thermodynamic predictions for OC-4 and SEM image showing a small amount of sigma formation after $2000 \mathrm{~h}$ ageing of $\mathrm{OC}-4$ at $650^{\circ} \mathrm{C}$.

Table 3. Nominal compositions of select exploratory modified OC-4 alloys

\begin{tabular}{|c|c|c|c|c|c|c|c|c|c|c|c|c|c|c|c|c|}
\hline \multirow{2}{*}{ Name } & \multicolumn{15}{|c|}{ Composition (wt\%) } & \multirow{2}{*}{ Remarks } \\
\hline & $\mathrm{Fe}$ & $\mathrm{Cr}$ & $\mathrm{Mn}$ & $\mathrm{Ni}$ & $\mathrm{Cu}$ & $\mathrm{Al}$ & $\mathrm{Si}$ & $\mathrm{Nb}$ & V & $\mathrm{Ti}$ & Mo & W & C & $B$ & $P$ & \\
\hline OC4 & 49.1 & 14 & 2 & 25 & 0.5 & 3.5 & 0.15 & 2.5 & 0.05 & 0.05 & 2.0 & 1.0 & 0.10 & 0.01 & 0.02 & $2 \mathrm{Mo}-2.5 \mathrm{Nb}$ \\
\hline AFA27 & 52.1 & 14 & 2 & 25 & 0.5 & 3.5 & 0.15 & 2.5 & 0.05 & 0.05 & 0 & 0 & 0.10 & 0.01 & 0.02 & $0 \mathrm{Mo}-2.5 \mathrm{Nb}$ \\
\hline AFA24 & 53.6 & 14 & 2 & 25 & 0.5 & 3.5 & 0.15 & 1.0 & 0.05 & 0.05 & 0 & 0 & 0.10 & 0.01 & 0.02 & $0 \mathrm{Mo}-1 \mathrm{Nb}$ \\
\hline AFA1 & 55.9 & 14.3 & 2 & 20 & 0.5 & 3 & 0.15 & 1.0 & & & 2.0 & 1.0 & 0.10 & 0.01 & 0.02 & $2 \mathrm{Mo}-1 \mathrm{Nb}$ \\
\hline
\end{tabular}

Eliminating Mo and $\mathrm{W}$ additions mitigated $\sigma$ phase formation, Figure 29, as well as lowered alloy raw material cost ( $\mathrm{Ni}, \mathrm{Nb}, \mathrm{Mo}$, and $\mathrm{W}$ content dominate alloy raw material cost). Detrimental effects were noted for oxidation resistance at $700^{\circ}$ and $800^{\circ} \mathrm{C}$ in humid air if $\mathrm{Mo}, \mathrm{Nb}$, and $\mathrm{W}$ were all decreased; however, elimination of Mo and $\mathrm{W}$ could be tolerated if the $\mathrm{Nb}$ level is kept high ( 2.5 wt.\%). Creep evaluation indicated that elimination of Mo and $\mathrm{W}$ significantly improved creep rupture life at $650^{\circ} \mathrm{C} / 250 \mathrm{MPa}$ but degraded it at $750^{\circ} \mathrm{C} / 100 \mathrm{MPa}$, Fig. 30. Despite the small amount of sigma 
formation, OC-4 still exhibited good creep elongations at rupture, indicating the sigma phase is not a major detriment in this composition range.
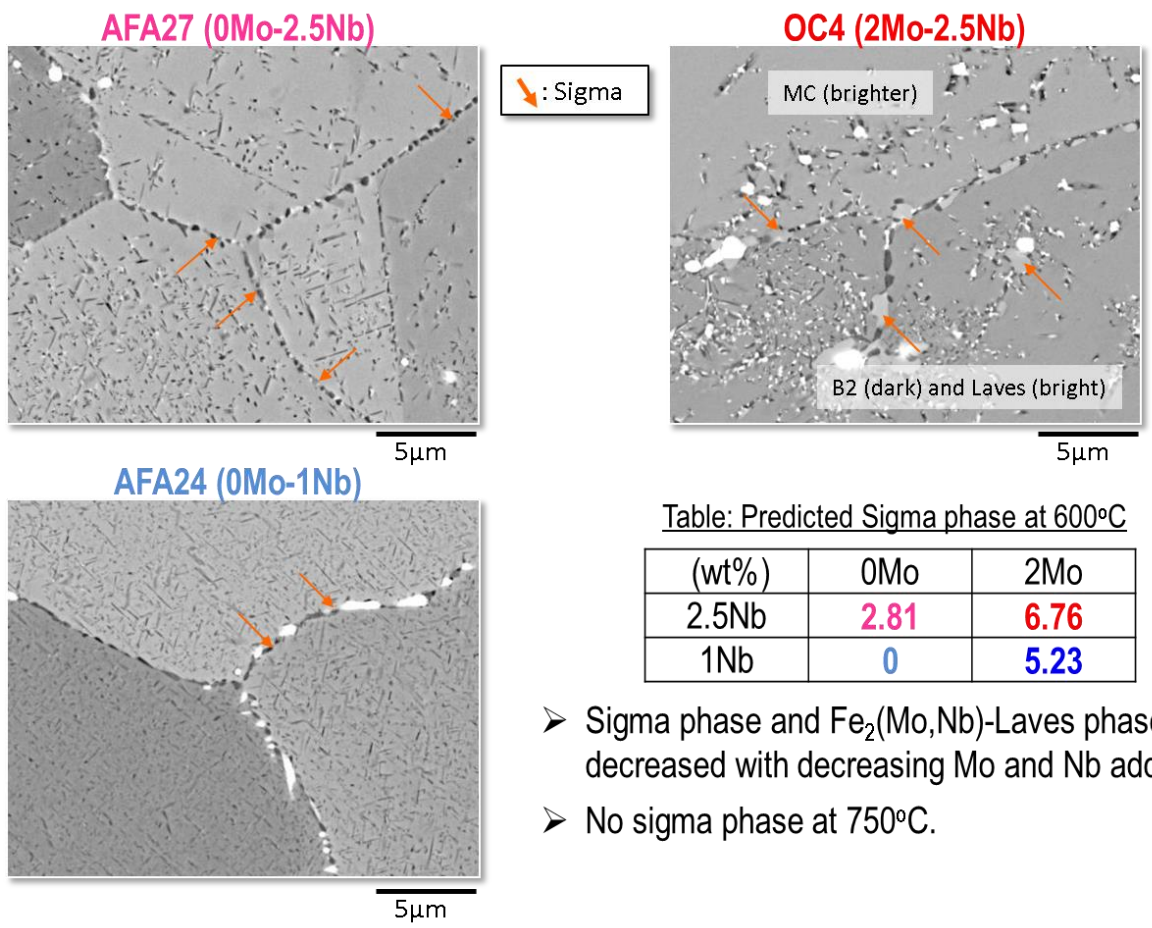

Table: Predicted Sigma phase at $600^{\circ} \mathrm{C}$

\begin{tabular}{|c|c|c|}
\hline$(\mathrm{wt} \%)$ & $0 \mathrm{Mo}$ & $2 \mathrm{Mo}$ \\
\hline $2.5 \mathrm{Nb}$ & 2.81 & 6.76 \\
\hline $1 \mathrm{Nb}$ & 0 & 5.23 \\
\hline
\end{tabular}

Sigma phase and $\mathrm{Fe}_{2}(\mathrm{Mo}, \mathrm{Nb})$-Laves phase decreased with decreasing $\mathrm{Mo}$ and $\mathrm{Nb}$ additions.

No sigma phase at $750^{\circ} \mathrm{C}$.

Fig. 29. Computational thermodynamic predictions for sigma phase and SEM image microstructures observed in modified OC-4 alloy AFA 24 and AFA 27 after $2000 \mathrm{~h}$ ageing of OC-4 at $\mathbf{6 5 0}^{\circ} \mathrm{C}$.
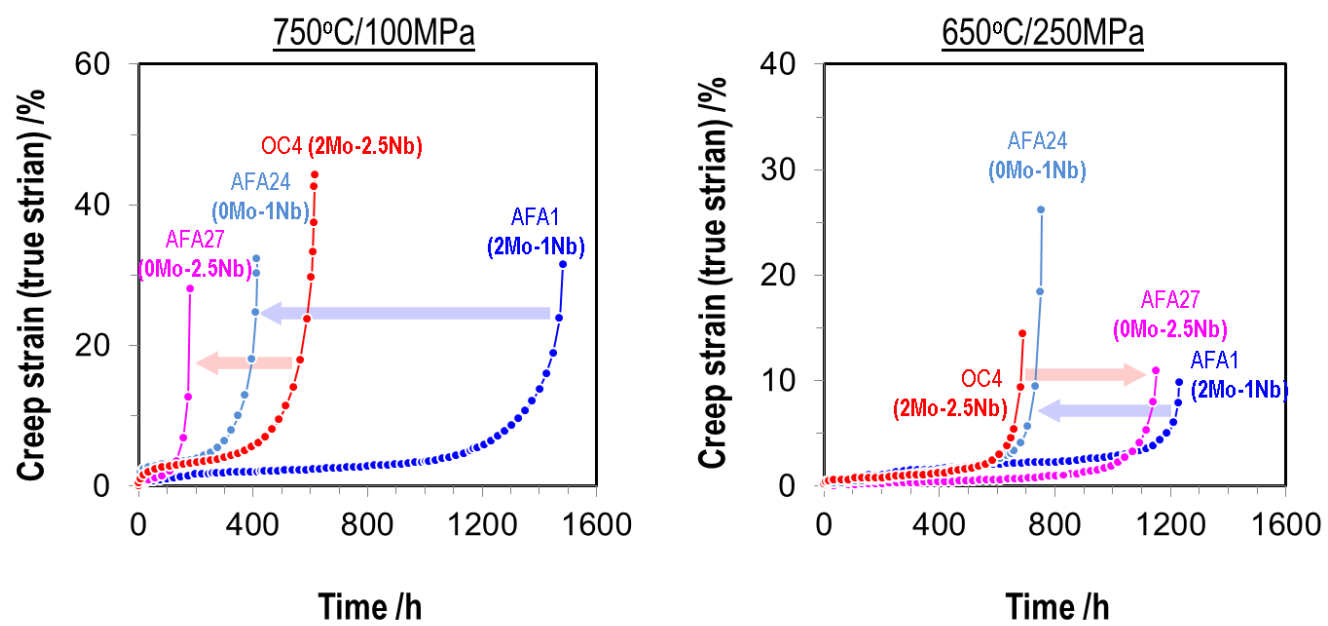

- At $750^{\circ} \mathrm{C}$; Less Mo resulted in poor creep resistance of both $2.5 \mathrm{Nb}$ and $1 \mathrm{Nb}$ alloys.

- At $650^{\circ} \mathrm{C}$; Less Mo increased creep-rupture life of only $2.5 \mathrm{Nb}$ alloys.

$\rightarrow$ Sigma phase would NOT degrade the creep properties at $650^{\circ} \mathrm{C}$.

Fig. 30. Creep data for modified OC-4 alloys. 


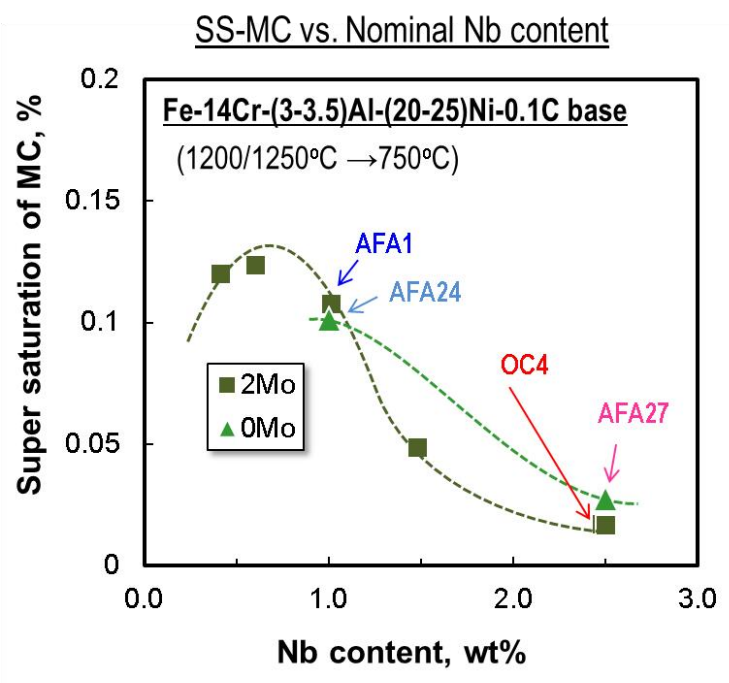

- Laves/B2 exhibit less strengthening effect (the size is too large to pin dislocations).

- Mo addition may increase the solution hardening.
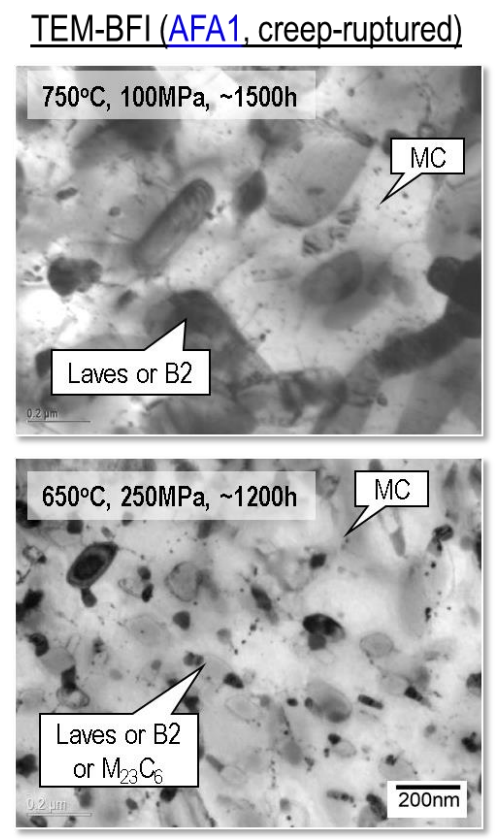

Fig. 31. Computational thermodynamic predictions for MC supersaturation vs. Nb content for modified OC-4 compositions and corresponding TEM bright field images after creep testing.

Reduction of $\mathrm{Nb}$ level to $1 \mathrm{wt}$ \% (which lowers alloy cost) significantly improved creep resistance (alloy AFA 1 in Fig. 30). The improved creep resistance at $1 \mathrm{wt} . \% \mathrm{Nb}$ was linked to increased MC supersaturation by computational thermodynamics, and confirmed by TEM imaging in crept samples, Figure 31. Reduction in $\mathrm{Nb}$ level from 2.5 to $1 \mathrm{wt} . \%$ did, however, reduce oxidation resistance (lower upper temperature use limit).

Transmission electron microscopy studies of the creep rupture tested microstructures showed that 10 $\mathrm{nm}$ range $\mathrm{L} 12 \mathrm{Ni}_{3} \mathrm{Al}$ precipitates were formed at $650^{\circ} \mathrm{C}$ in the higher-Nb containing alloys such as OC4, Figure 32. Computational thermodynamic assessment indicated that this $\mathrm{L} 12 \mathrm{Ni}_{3} \mathrm{Al}$ formation was metastable, and ageing studies confirmed loss of $\mathrm{L} 12 \mathrm{Ni}_{3} \mathrm{Al}$ in the $\sim 5000 \mathrm{~h}$ range. This phenomenon resulted in over prediction of the creep resistance of OC-4 below $700^{\circ} \mathrm{C}$, based on extrapolation of short-term creep test results for which the $\mathrm{L} 12 \mathrm{Ni}_{3} \mathrm{Al}$ phase was still present. Modified compositions for improved microstructure stability are discussed in section 3.3.1, based on $1 \mathrm{wt} . \% \mathrm{Nb}$ levels. The observations of metastable $\mathrm{L} 12 \mathrm{Ni}_{3} \mathrm{Al}$ in OC-4 provided the fundamental basis for development of a stable $\mathrm{L} 12 \mathrm{Ni}_{3} \mathrm{Al}$ strengthened class of AFA superalloys with improved creep resistance under separate funding from the Defense Advanced Research Project Agency (DARPA). 

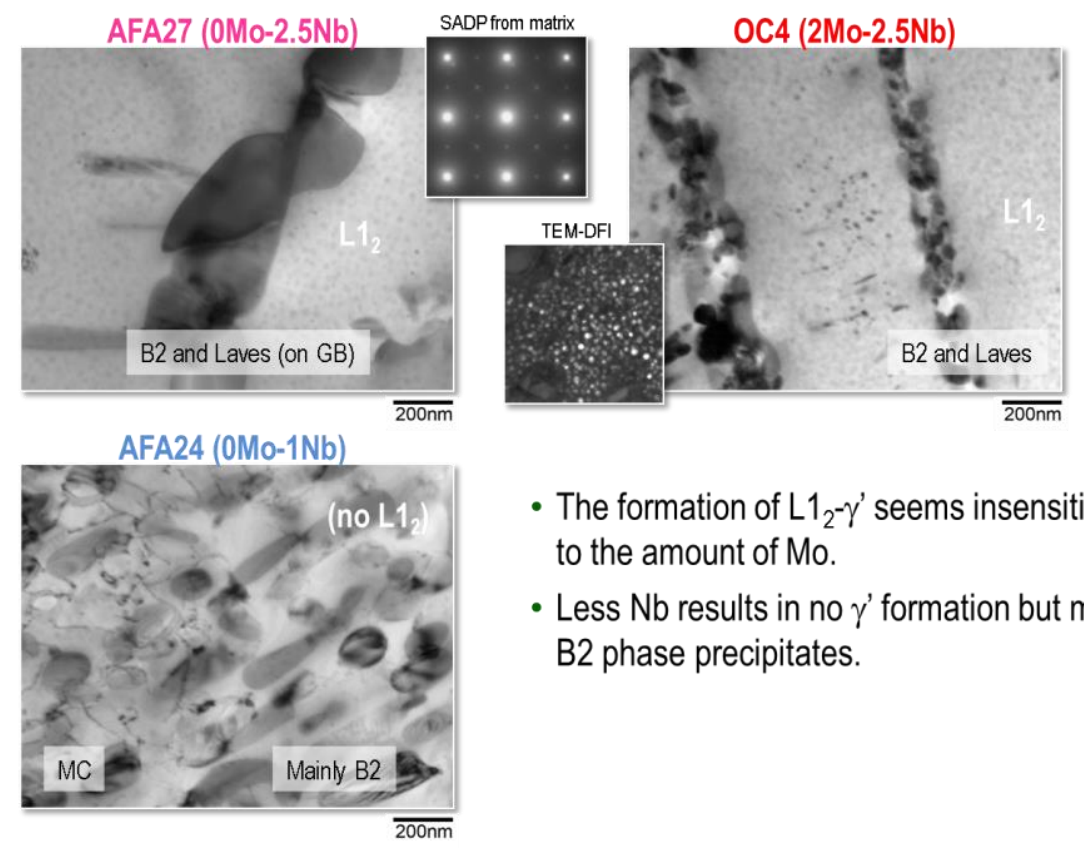

- The formation of $\mathrm{L}_{2}-\gamma^{\prime}$ seems insensitive to the amount of Mo.

- Less $\mathrm{Nb}$ results in no $\gamma^{\prime}$ formation but many B2 phase precipitates.

Fig. 32. TEM bright field images for modified $\mathrm{OC}-4$ compositions after creep testing at $650^{\circ} \mathrm{C}$.

The oxidation behavior of a series of exploratory AFA alloys was also systematically studied as a function of levels of $\mathrm{Cr}, \mathrm{Si}, \mathrm{Al}, \mathrm{C}$, and B additions to an initially optimized AFA alloy base in an effort to increase the upper-temperature oxidation limit (Table 4). Oxidation exposures were conducted in air with $10 \%$ water vapor environments from $800-950^{\circ} \mathrm{C}$ and the specimens were characterized after exposure. Increased levels of $\mathrm{Al}, \mathrm{C}$ and $\mathrm{B}$ were found to improve the oxidation resistance (Fig. 33). This represents a potential $\sim 100-150^{\circ} \mathrm{C}$ increase in the maximum use temperature of AFA alloys.

Table 4. Analyzed compositions of AFA alloys studied for increase upper temperature oxidation limit

\begin{tabular}{|l|l|l|l|l|l|l|l|l|l|l|}
\hline Alloy & Ni & $\mathbf{C r}$ & $\mathbf{A l}$ & $\mathbf{N b}$ & $\mathbf{M n}$ & $\mathbf{M o}$ & $\mathbf{S i}$ & $\mathbf{C}$ & $\mathbf{B}$ & $\mathbf{R E E}$ \\
\hline AFA base & 25.2 & 14.9 & 3.0 & 2.5 & 1.9 & 2.0 & 0.15 & 0.09 & 0.01 & $\begin{array}{l}0.009 \mathrm{Y} \\
0.13 \mathrm{Hf}\end{array}$ \\
\hline AFA+Cr & 25.2 & 16.9 & 3.0 & 2.5 & 1.9 & 2.0 & 0.15 & 0.10 & 0.008 & $\begin{array}{l}0.011 \mathrm{Y} \\
0.13 \mathrm{Hf}\end{array}$ \\
\hline AFA+Si & 25.1 & 15 & 3.0 & 2.5 & 1.9 & 2.0 & 0.4 & 0.09 & 0.007 & $\begin{array}{l}0.006 \mathrm{Y} \\
0.14 \mathrm{Hf}\end{array}$ \\
\hline AFA+Al & 25.1 & 14.9 & 4.0 & 2.5 & 1.9 & 2.0 & 0.15 & 0.09 & 0.011 & $\begin{array}{l}0.009 \mathrm{Y} \\
0.14 \mathrm{Hf}\end{array}$ \\
\hline AFA+C & 25.2 & 14.9 & 3.0 & 2.5 & 1.9 & 2.0 & 0.15 & 0.20 & 0.012 & $\begin{array}{l}0.014 \mathrm{Y} \\
0.014 \mathrm{Hf}\end{array}$ \\
\hline AFA+B & 25.2 & 14.9 & 3.0 & 2.5 & 1.9 & 2.0 & 0.15 & 0.10 & 0.107 & $\begin{array}{l}0.008 \mathrm{Y} \\
0.14 \mathrm{Hf}\end{array}$ \\
\hline
\end{tabular}




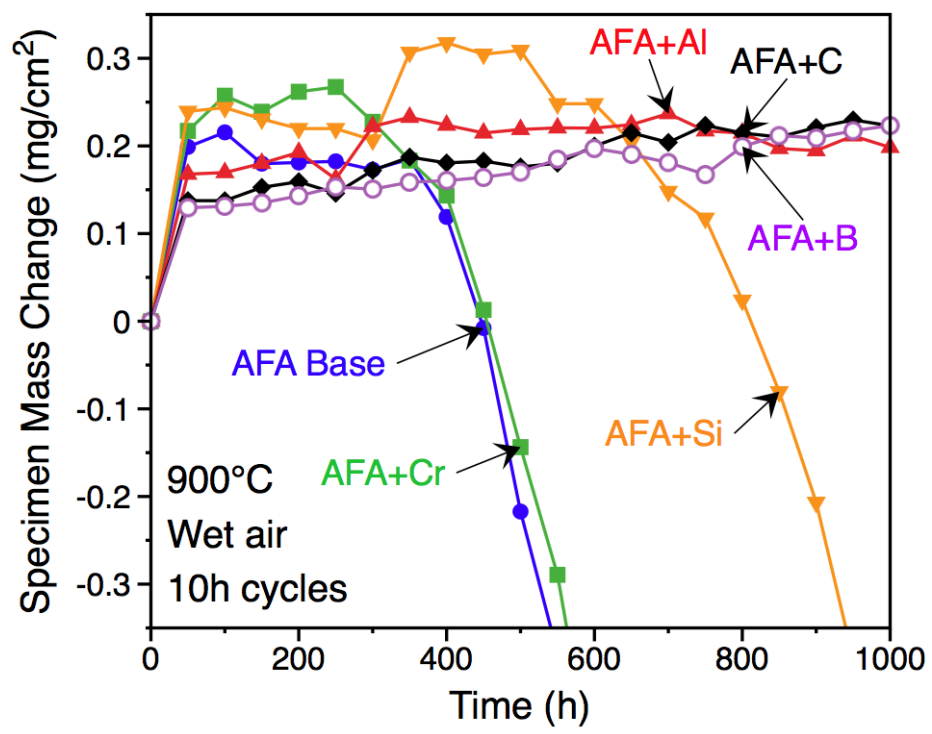

Fig. 33. Mass gain of modified AFA alloys exposed in $10 \mathrm{~h}$ cycles at $900^{\circ} \mathrm{C}$ in air with $10 \% \mathrm{H2O}$.

\subsubsection{Low Cost AFA Alloy Compositions for Tube Applications}

Carpenter Technology Corporation's market analysis indicated assessment and optimization of lower $\mathrm{Nb}$ and $\mathrm{Ni}$ (lower cost) AFA alloy compositions for applications below $\sim 750-800^{\circ} \mathrm{C}$ were of highest priority. A further aspect important for widespread commercialization of AFA is that secondary processing of AFA alloys to end user specific product forms may involve additional alloy processing beyond product form delivered by Carpenter (e.g. wide width foil, tube, etc.). In some cases, these secondary manufacturers cannot readily achieve the $1200^{\circ} \mathrm{C}$ annealing condition to yield optimal creep resistance for the OC-4 and related AFA alloys. The impact of lower temperature annealing on AFA alloys is very alloy composition specific. The effects of annealing temperature on three lower $\mathrm{Nb}$ (lower cost) AFA alloys were evaluated for OC-5 (Fe-25Ni-14Cr-3Al-2Mn-2Mo-1Nb-1W-0.5Cu$0.1 \mathrm{C}-0.01 \mathrm{~B}$ wt. \%), OC-B (Fe-25Ni-14Cr-3Al-2Mn-2Mo-1Nb-1W-0.5Cu-0.2C-0.01B wt.\%), and OC$\mathrm{G}$ (Fe-20Ni-14Cr-3Al-2Mn-2Mo-1W-1Nb-0.5Cu-0.2C-0.01B). These compositions were initially developed under CRADA and Grand Challenge activities with Carpenter.

Table 5 shows creep rupture lifetimes at $650^{\circ}-750^{\circ} \mathrm{C}$ with relatively high stresses to induce $\sim 1000 \mathrm{~h}$ lifetimes. Previous data obtained with a standard $1204^{\circ} \mathrm{C}$ anneal was compared to lower temperature annealing temperatures. As expected, the lower temperature anneals decreased creep life, especially at $750^{\circ} \mathrm{C}$. However, the decrease was relatively minor for alloy OCG. It should be noted that even with the lower temperature solutionizing, all 3 alloys still exhibited better creep rupture lifetimes than OC-4 under these conditions. The trade-off is that these lower cost but higher creep resistant AFA compositions cannot form protective alumina to as high a temperature as OC-4. OC-4 formed protective alumina to the $\sim 900^{\circ} \mathrm{C}$ range, whereas the upper temperature limit for the $1 \mathrm{Nb} w \mathrm{wt} \% \mathrm{AFA}$ compositions is in the range of $\sim 750-800^{\circ} \mathrm{C}$. However, this still places them within the Carpenter market analysis indicated high priority temperature range of interest. 
Table 5. Effect of annealing temperature on creep rupture lifetime

\begin{tabular}{|l|l|l|l|l|l|l|}
\hline Creep Test & \multicolumn{2}{|c|}{ Alloy OC-5 } & \multicolumn{2}{c|}{ Alloy OC-B } & \multicolumn{2}{c|}{ Alloy OC-G } \\
\hline & Annealing Temperatures/Creep Rupture Lifetimes (h) \\
\hline & $1204^{\circ} \mathrm{C}$ & $1149^{\circ} \mathrm{C}$ & $1204^{\circ} \mathrm{C}$ & $1093^{\circ} \mathrm{C}$ & $1204^{\circ} \mathrm{C}$ & $1093^{\circ} \mathrm{C}$ \\
\hline $750^{\circ} \mathrm{C} / 100 \mathrm{MPa}$ & $1581 \mathrm{~h}$ & $707 \mathrm{~h}$ & $1457 \mathrm{~h}$ & $823 \mathrm{~h}$ & $1490 \mathrm{~h}$ & $886 \mathrm{~h}$ \\
\hline $700^{\circ} \mathrm{C} / 170 \mathrm{MPa}$ & $611 \mathrm{~h}$ & $570 \mathrm{~h}$ & ------ & $515 \mathrm{~h}$ & ----- & $1005 \mathrm{~h}$ \\
\hline $650^{\circ} \mathrm{C} / 250 \mathrm{MPa}$ & $1314 \mathrm{~h}$ & $1066 \mathrm{~h}$ & $905 \mathrm{~h}$ & $459 \mathrm{~h}$ & $1063 \mathrm{~h}$ & $992 \mathrm{~h}$ \\
\hline
\end{tabular}

Based on its good behavior in creep screening, alloy OC-G (with its lower $1 \mathrm{Nb}$ and $20 \mathrm{Ni}$ levels) and the lowest cost $12 \mathrm{Ni} \mathrm{AFA}^{\mathrm{LN}}$ grade alloy OC-I (Fe-14Cr-12Ni-5Mn-3Cu-2.5Al-1Nb-0.2C-0.01B), which was identified under the Carpenter Grand Challenge effort has having significant promise, were selected for additional study. Results from longer term creep rupture life test conditions (Fig. 34.) indicated good creep resistance was maintained by these alloys, along with ductile failure elongations $>10 \%$. Figure 35 shows a Larson-Miller parameter plot for these lower cost OC-G and OC-I alloys, relative to OC-4 and commercial stainless steels and Ni-base alloys. The OC-G and OC-I alloys exhibit better creep resistance than $\mathrm{OC}-4$, in the range of the best commercial chromia-forming austenitic $\mathrm{NF709,}$ despite their lower $\mathrm{Ni}$ and $\mathrm{Nb}$ contents. Also shown for comparison is the $\mathrm{L} 12 \mathrm{Ni}_{3} \mathrm{Al}$ strengthened AFA superalloy DAFA 29, which was developed under a separate effort with DARPA based on metastable L12 phase observed in the present program in OC-4. At lower temperatures this alloy exhibits creep strength nearly comparable to the costly Ni-base alloy 617. 

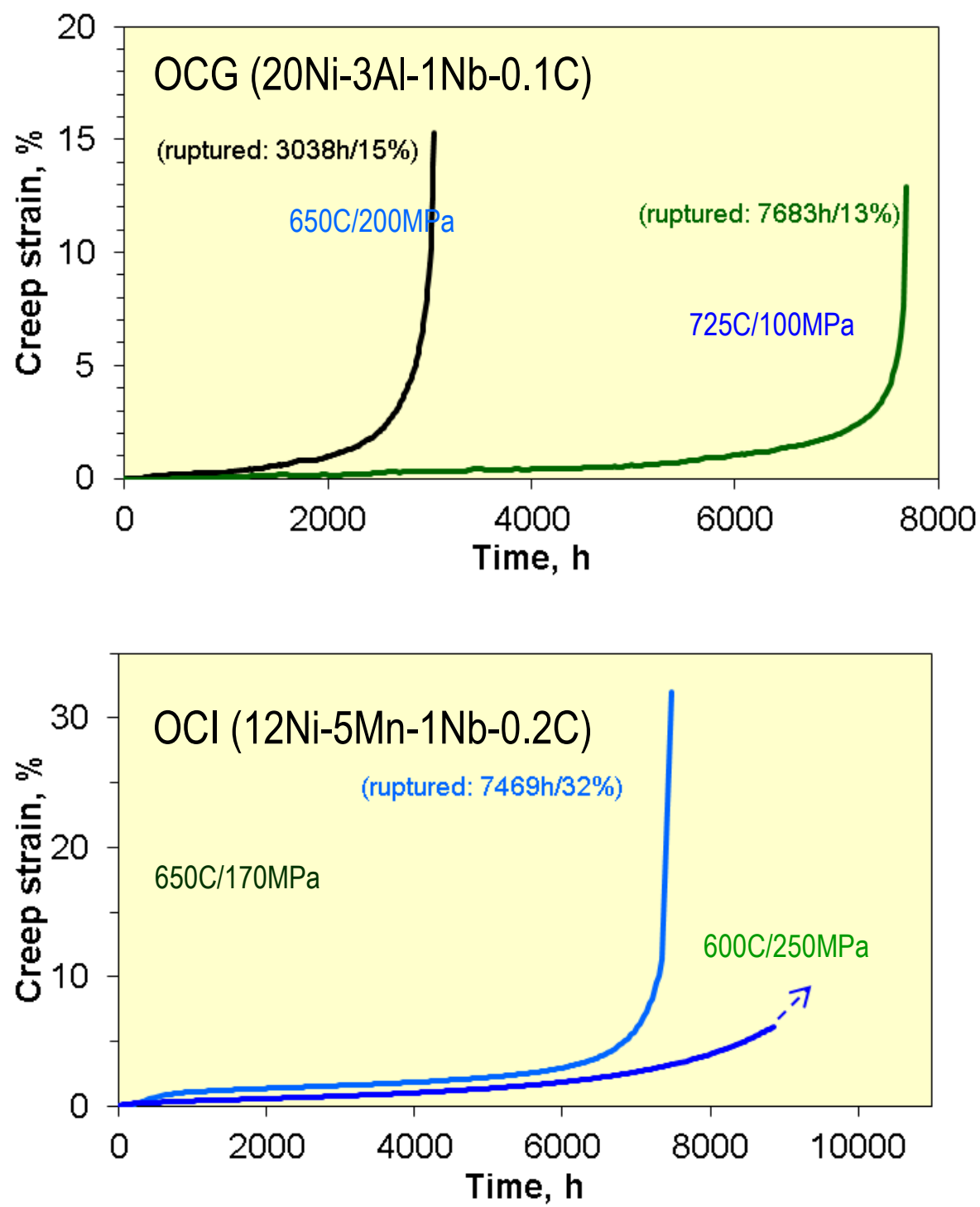

Fig. 34. Creep rupture life curves for low cost AFA alloys OC-G and OC-I. 


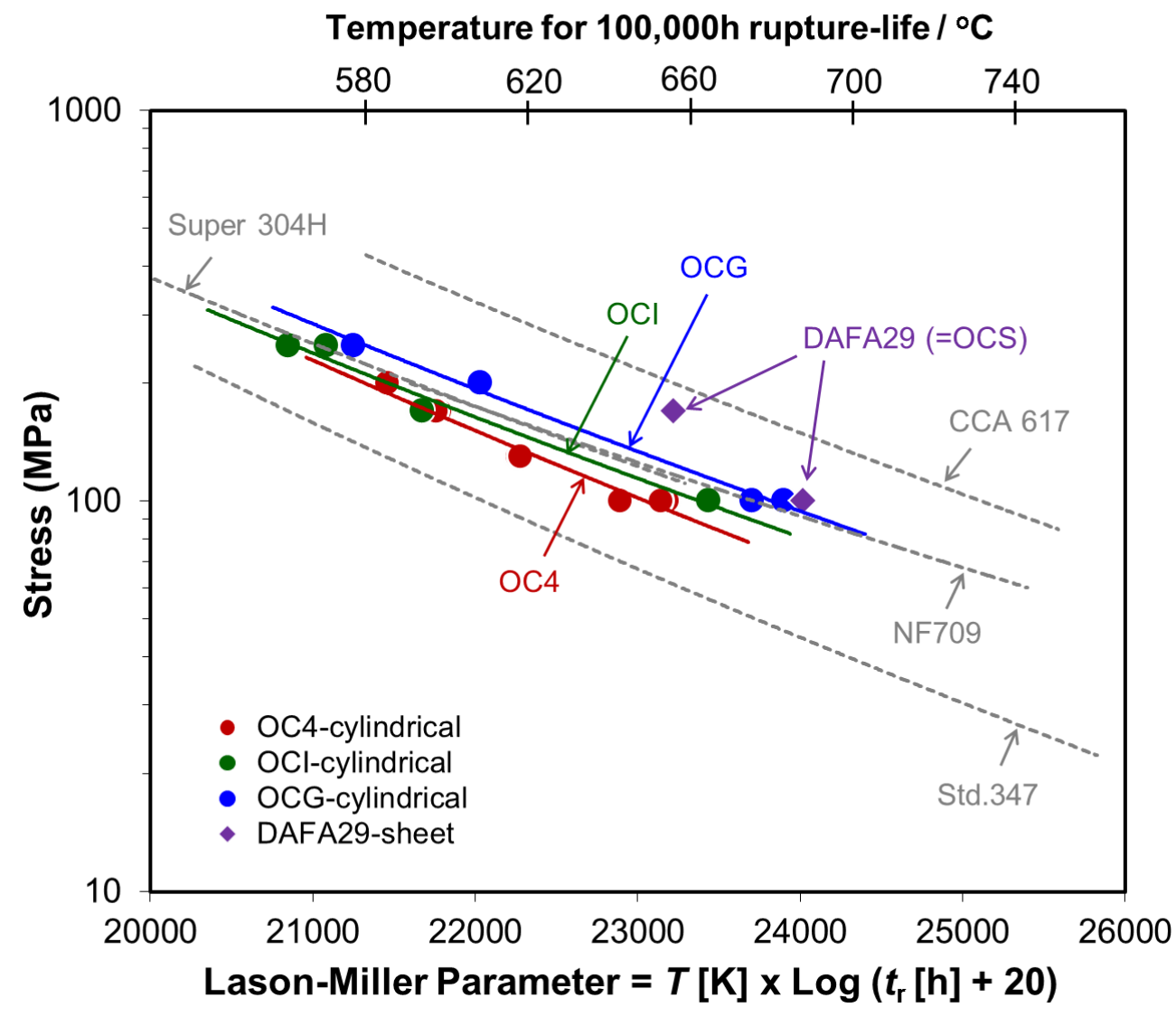

Fig. 35. Larson-Miller Parameter (LMP) creep plot update for low cost AFA alloys.

Trial 25lb heats for composition specification range variations of OC-G (alloys OC-N, O, and $\mathrm{P}$ ) and OC-I (alloys OC-Q, R) were manufactured and evaluation by Carpenter and ORNL to provide the basis to move these alloys to consideration for production heats. Creep rupture testing results at $650^{\circ} \mathrm{C} / 250 \mathrm{MPa}, 700^{\circ} \mathrm{C} / 170 \mathrm{MPa}$, and $750^{\circ} \mathrm{C} / 100 \mathrm{MPa}$ are shown in Table 6 . The creep rupture data showed that in the $20 \mathrm{Ni}$ wt.\% alloy series, reducing $\mathrm{C}$ level from $0.2 \mathrm{wt} . \%$ (OC-G) to $0.15 \mathrm{wt} . \%$ (OC$\mathrm{N})$ did not degrade creep resistance. Rather, it moderately enhanced rupture life. However, reducing alloy cost by removing $1 \mathrm{wt} . \% \mathrm{~W}$ (OC-O) or reducing the $\mathrm{Nb}$ content from 1 to $0.6 \%$ (OC-P) degraded creep rupture life. For the $12 \% \mathrm{Ni}$ base alloy OC-I, reducing Nb from 1 to $0.6 \%$ (OC-Q, OC-R), with additional variations in $\mathrm{Ni}, \mathrm{Cr}$, and $\mathrm{Mn}$ content, also resulted in degradation in creep rupture life. Together these findings help provide a basis for setting composition specification ranges for possible future scale up. 
Table 6. Carpenter creep rupture data for low cost, lower Ni AFA alloy heats

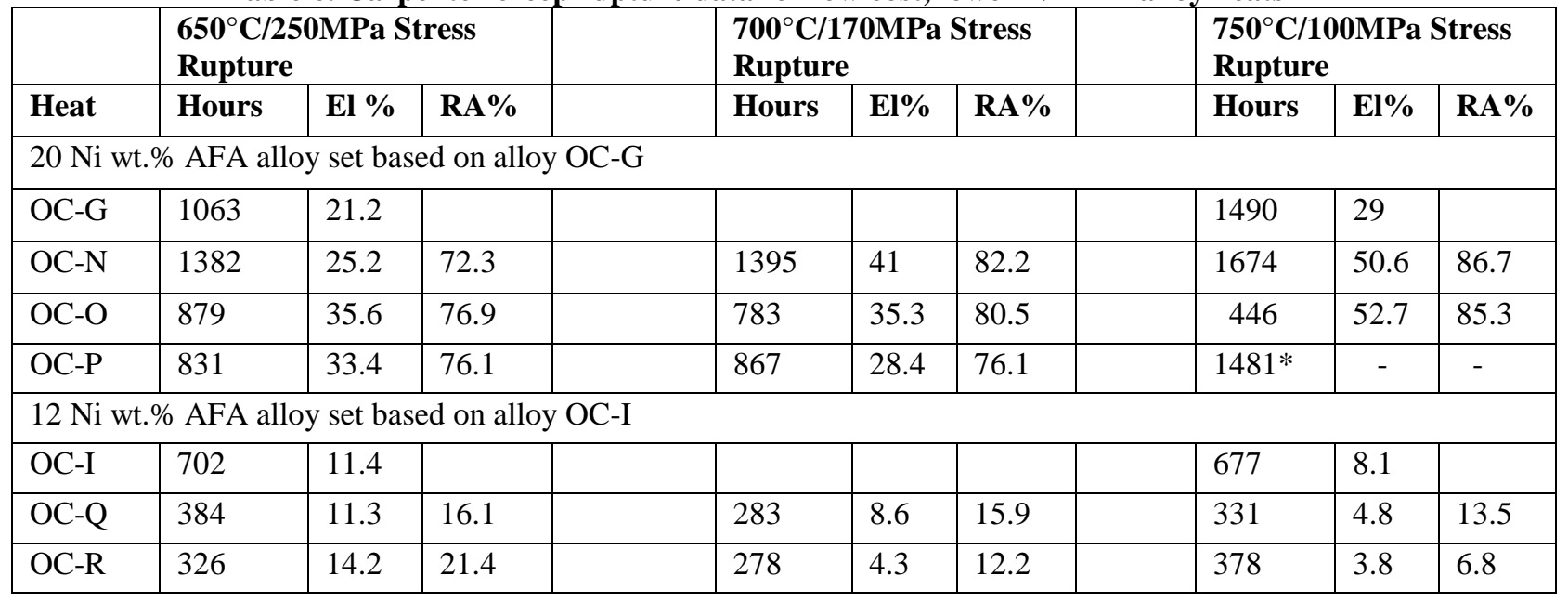

*EL and RA to be measured

Figure 36 shows oxidation data at $700^{\circ}$ and $800^{\circ} \mathrm{C}$ in air $+10 \% \mathrm{H}_{2} \mathrm{O}$ obtained at ORNL for the 5 new low $\mathrm{Ni}$ alloy variations, OC-G, OC-I, and the $25 \% \mathrm{Ni}$ OC-5 AFA alloy relative to commercial austenitics. At $800^{\circ} \mathrm{C}$, the $20 \% \mathrm{Ni}$ AFA alloys OC-N, O, P, and G showed superior oxidation resistance to the comparison commercial chromia-forming austenitics alloy $709(\sim \mathrm{Fe}-25 \mathrm{Ni}-20 \mathrm{Cr}$ wt.\% base), $310 \mathrm{HCbN}(\sim \mathrm{Fe}-20 \mathrm{Ni}-25 \mathrm{Cr}$ wt. $\%$ base), and $22 \mathrm{Cr} 25 \mathrm{NiWCoCu}(\sim \mathrm{Fe}-22 \mathrm{Cr}-25 \mathrm{Ni}$ wt. $\%$ base$)$ out to 1500-2000 h of ongoing exposure. Data for alloy OC-G showed a loss of protective alumina formation after $\sim 4500 \mathrm{~h}$ of exposure, indicating its maximum use temperature is below $800^{\circ} \mathrm{C}$ in air + $10 \% \mathrm{H}_{2} \mathrm{O}$. Data for AFA OC-5 is shown for 5,000 h in Figure 36, but this specimen has been exposed for $10,000 \mathrm{~h}$ with good oxidation resistance at $800^{\circ} \mathrm{C}$, consistent with its higher Ni level. At $700^{\circ}$ and $750^{\circ} \mathrm{C}$ in air $+10 \% \mathrm{H}_{2} \mathrm{O}$, alloy OC-G has accumulated $5000 \mathrm{~h}$ with good resistance thus far $\left(750^{\circ} \mathrm{C}\right.$ data not shown). In wet air at $700^{\circ} \mathrm{C}$, OC-I showed loss of protective alumina scale formation at $\sim 3000 \mathrm{~h}$ of exposure. However, this level of oxidation resistance was still superior to that of the $\sim \mathrm{Fe}-$ $18 \mathrm{Cr}-10 \mathrm{Ni}$ wt. $\%$ base commercial chromia-forming alloys 347 and super $304 \mathrm{H}$, which showed a transition to extensive spallation after only a few hundred hours of exposure, Figure 2. At $650^{\circ} \mathrm{C}$ in air $+10 \% \mathrm{H}_{2} \mathrm{O}$ (data not shown), both OC-I and OC-G have accumulated $5000 \mathrm{~h}$ of exposure with good oxidation resistance. 


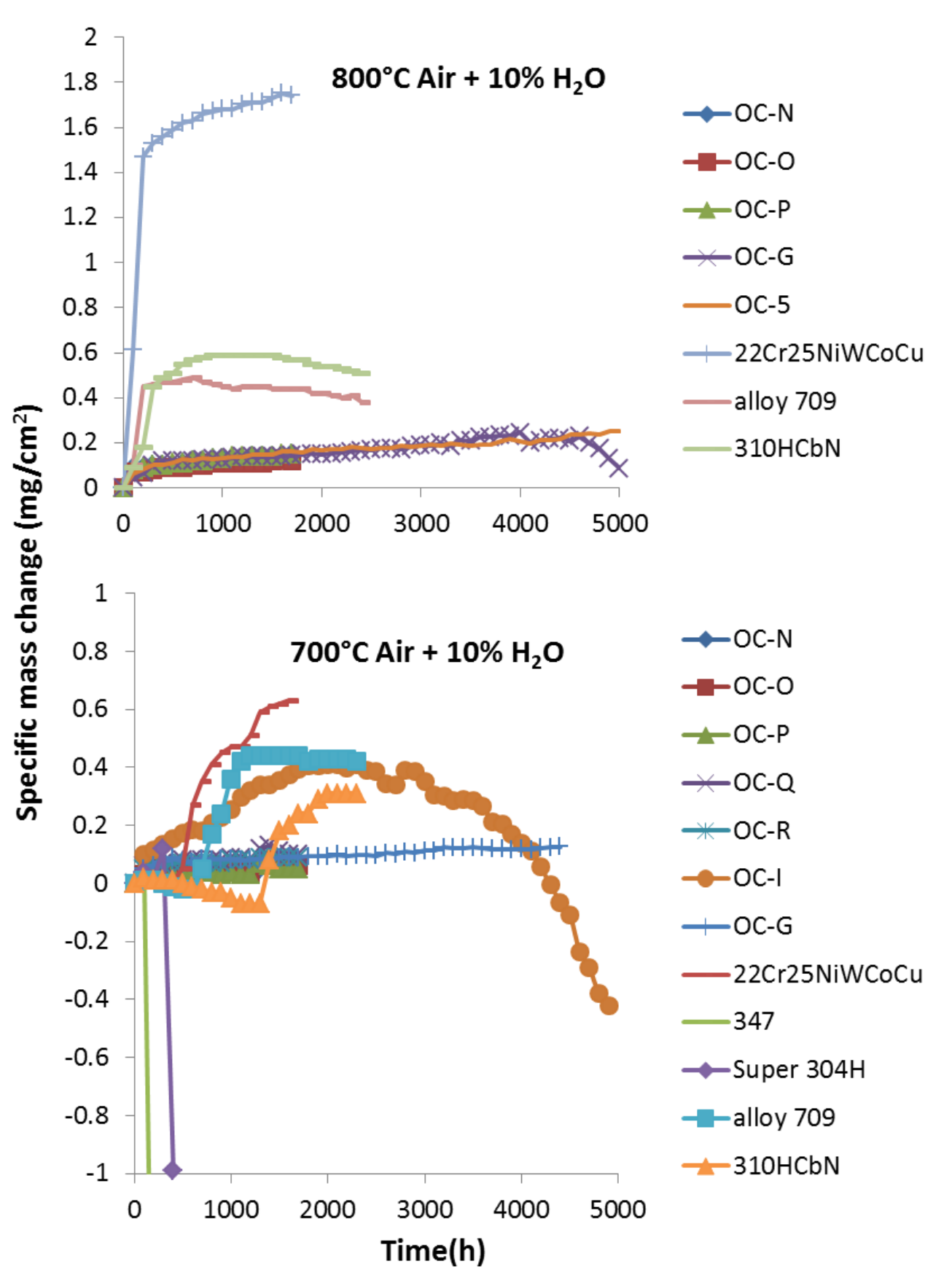

Fig. 36. Oxidation data for baseline and modified low Ni AFA alloys ON-N - OC-R, OC-G, and OC-I relative to $25 \% \mathrm{Ni} \mathrm{AFA}$ alloy $\mathrm{OC}-5\left(800^{\circ} \mathrm{C}\right.$ only) and commercial austenitics at $700^{\circ}$ and $800^{\circ} \mathrm{C}$ in air $+10 \% \mathrm{H} 2 \mathrm{O}$.

Carpenter Technology Corporation has received considerable interest in AFA alloys for metal dusting conditions encountered in a variety of $\mathrm{H}_{2}$ reforming and related chemical and petrochemical industry applications. To assist in metal dusting evaluations in a thermal gradient, ORNL post-processed OC-4 (Fe-25Ni-14Cr-3.5Al-2.5Nb-2Mn-2Mo-1W-0.5Cu-0.1C-0.01B wt.\%) and OC-I (Fe-14Cr-12Ni-5Mn$3 \mathrm{Cu}-2.5 \mathrm{Al}-1 \mathrm{Nb}-0.2 \mathrm{C}-0.01 \mathrm{~B}$ ) into rectangular cross-section rods needed by Carpenter partners. Figure 37 shows the rods that were delivered for testing. 
Previous end-user feedback indicated poor corrosion resistance of AFA alloy OC-4 under hydrogen reforming/metal dusting conditions. This is speculated to be a consequence of the relatively low temperatures and low $\mathrm{pO}_{2}$ resulting in sluggish alumina formation, and the extensive use of carbideforming elements in AFA alloys to achieve creep strength. Poor behavior of OC-4 was confirmed in Carpenter partner's gradient testing. However, the $12 \mathrm{Ni}$ AFA ${ }^{\mathrm{LN}}$ alloy OC-I showed very promising levels of metal dusting resistance under metal dusting conditions at Carpenter's partner's gradient metal dusting evaluation protocol (long rod coupons from Figure 37. Additional OC-I test material has therefore been delivered to this industrial end user, and evaluation of OC-I under metal dusting conditions will continue by this end user in 2013 and 2014. If the additional testing confirms good metal dusting resistance by OC-I, this opens up a significant potential market for AFA tube form material in chemical/petrochemical processing.

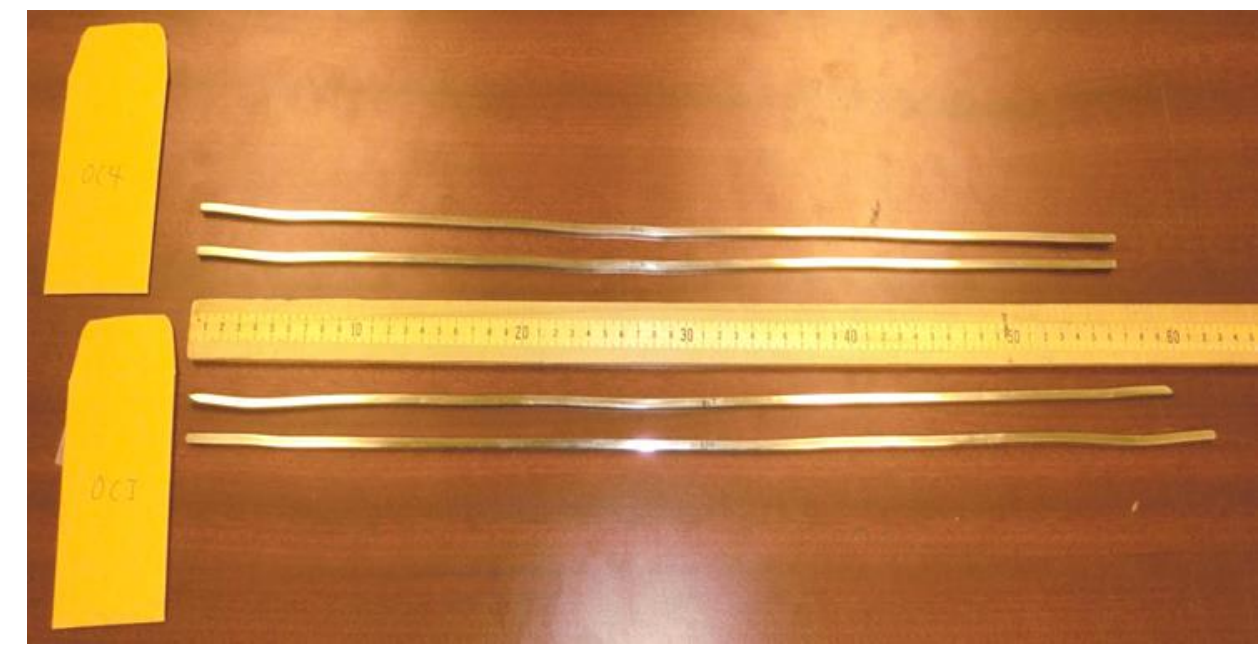

Fig. 37. OC-4 and OC-I rods manufactured by ORNL for gradient metal dusting condition evaluation.

\subsection{TASK 4. EVALUATION OF AS-CAST PROPERTIES}

The initially developed AFA alloys were designed to be wrought. However, some applications such as turbine casings and ducts or tubes require manufacture from as-cast alloys. The goal of Task 4 evaluation of as-cast properties was to assess the feasibility of cast forms of AFA alloys. This required modification of AFA alloy base compositions to yield high levels of property performance in as-cast structures. This work led to an additional AFA alloy patent for cast forms of AFA (Cast Alumina Forming Austenitic Stainless Steels, US 8,431,072 B2 Apr. 30, 2013) and a successful trial scale tube manufacture by Duraloy Technologies, Inc.

Table 7. Analyzed chemical compositions of as-cast trial AFA alloys

\begin{tabular}{cccccccccccccccc}
\hline Name & ID & $\mathrm{Fe}$ & $\mathrm{Cr}$ & $\mathrm{Mn}$ & $\mathrm{Ni}$ & $\mathrm{Cu}$ & $\mathrm{Al}$ & $\mathrm{Si}$ & $\mathrm{Nb}$ & $\mathrm{Mo}$ & $\mathrm{W}$ & $\mathrm{C}$ & $\mathrm{B}$ & $\mathrm{P}$ & $\begin{array}{c}\mathrm{N} \\
\text { (ppm) }\end{array}$ \\
\hline Base & OC4 & 49.1 & 13.9 & 1.94 & 25.2 & 0.50 & 3.47 & 0.15 & 2.49 & 2.00 & 1.00 & 0.09 & 0.006 & 0.019 & 5 \\
\hline Alloy 1 & CAFA 1 & 49.7 & 14.0 & 1.92 & 25.1 & 0.51 & 3.56 & 0.94 & 0.95 & 1.98 & 0.99 & 0.20 & 0.009 & 0.020 & 5 \\
Alloy 2 & CAFA 2 & 48.3 & 14.0 & 1.94 & 25.2 & 0.51 & 3.46 & 0.93 & 2.42 & 1.98 & 0.98 & 0.22 & 0.010 & 0.016 & 17 \\
Alloy 3 & CAFA 3 & 48.8 & 14.1 & 1.97 & 24.9 & 0.51 & 3.51 & 2.04 & 0.89 & 1.98 & 0.90 & 0.19 & 0.012 & 0.019 & 11 \\
Alloy 4 & CAFA 4 & 49.9 & 14.1 & 1.92 & 25.3 & 0.51 & 3.49 & 0.48 & 0.94 & 1.98 & 1.00 & 0.29 & 0.008 & 0.020 & 12 \\
Alloy 5 & CAFA 6 & 49.3 & 13.9 & 1.95 & 25.5 & 0.48 & 3.51 & 0.98 & 0.88 & 1.99 & 0.97 & 0.45 & 0.008 & 0.003 & 4 \\
\hline *All alloys contain 0.05V and 0.05Ti.
\end{tabular}


Table 7 shows baseline OC-4 composition and 5 candidate as-cast alloy compositions, with varying levels of $\mathrm{C}, \mathrm{Si}$, and $\mathrm{Nb}$ levels. Computational thermodynamic calculations indicated increased levels of $\mathrm{C}$ additions, at lower levels of $\mathrm{Nb}$ addition, held the potential to result in significant levels of $\mathrm{M}_{23} \mathrm{C}_{6}$ $\left(\mathrm{M}=\mathrm{Nb}, \mathrm{Cr}\right.$ primarily) strengthening precipitates (Fig. 38). Creep tests at $750^{\circ} \mathrm{C} / 100 \mathrm{MPa}$ are shown in Figure 39 for laboratory arc-cast alloys. Increased $\mathrm{Nb}$ or Si levels at increased $\mathrm{C}$ levels (alloys 2,3) did not result in improved creep resistance over cast OC-4 baseline composition. However, proper selection of $\mathrm{Nb}$ and $\mathrm{Si}$ content resulted in significantly improved creep resistance, which increased with $\mathrm{C}$ addition level. The LMP plot shown in Figure 40 indicates that the best cast alloys (alloys 4 and 5) exhibit creep resistance comparable to the commercial HK alloys. However, as can be seen in the oxidation data (Fig. 41), the alumina-forming cast AFA alloys exhibit superior high temperature oxidation resistance to the chromia-forming HK and HP alloys (data on HK and HP alloys was generated on a different DOE project). The alloy 5 with the highest level of $\mathrm{C}$ at $0.5 \mathrm{wt} . \%$, and best creep resistance, showed a degraded oxidation resistance relative to lower $\mathrm{C}$ content cast AFA compositions, although the oxidation resistance was still superior to the commercial HK and HP alloys.
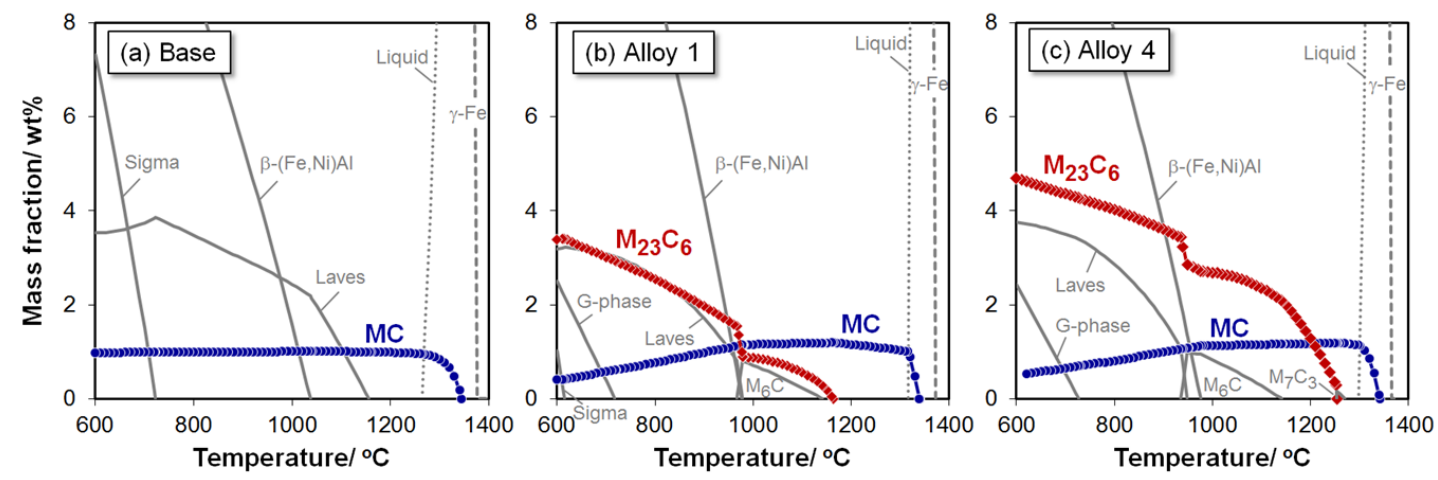

Fig. 38. Computational thermodynamic calculation results used to guide and assess candidate cast AFA composition development.

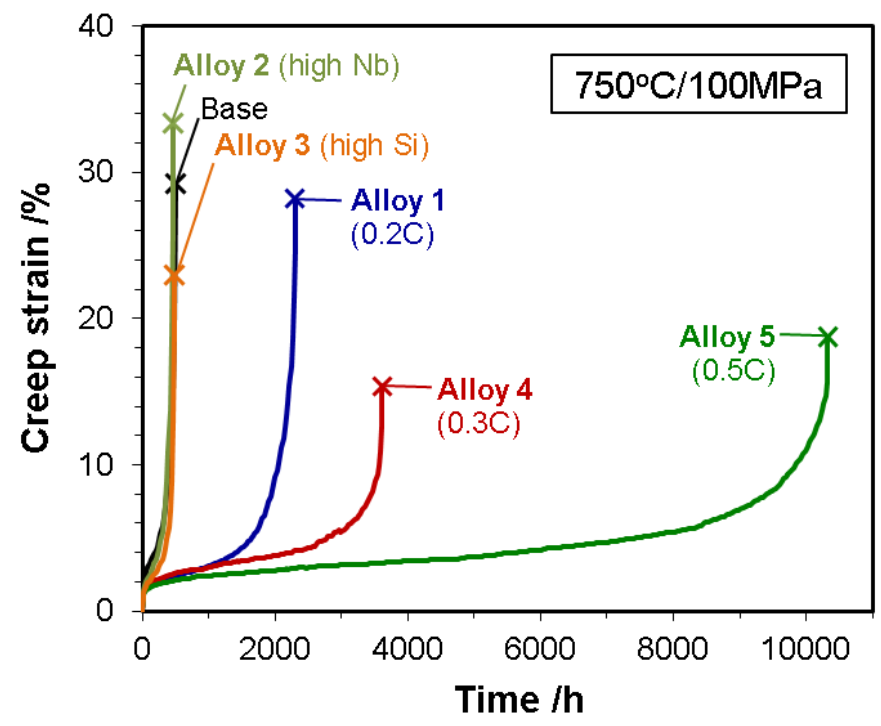

Fig. 39. Creep strain as a function of time for candidate cast alloys vs. the $\mathrm{OC}-4$ base. 


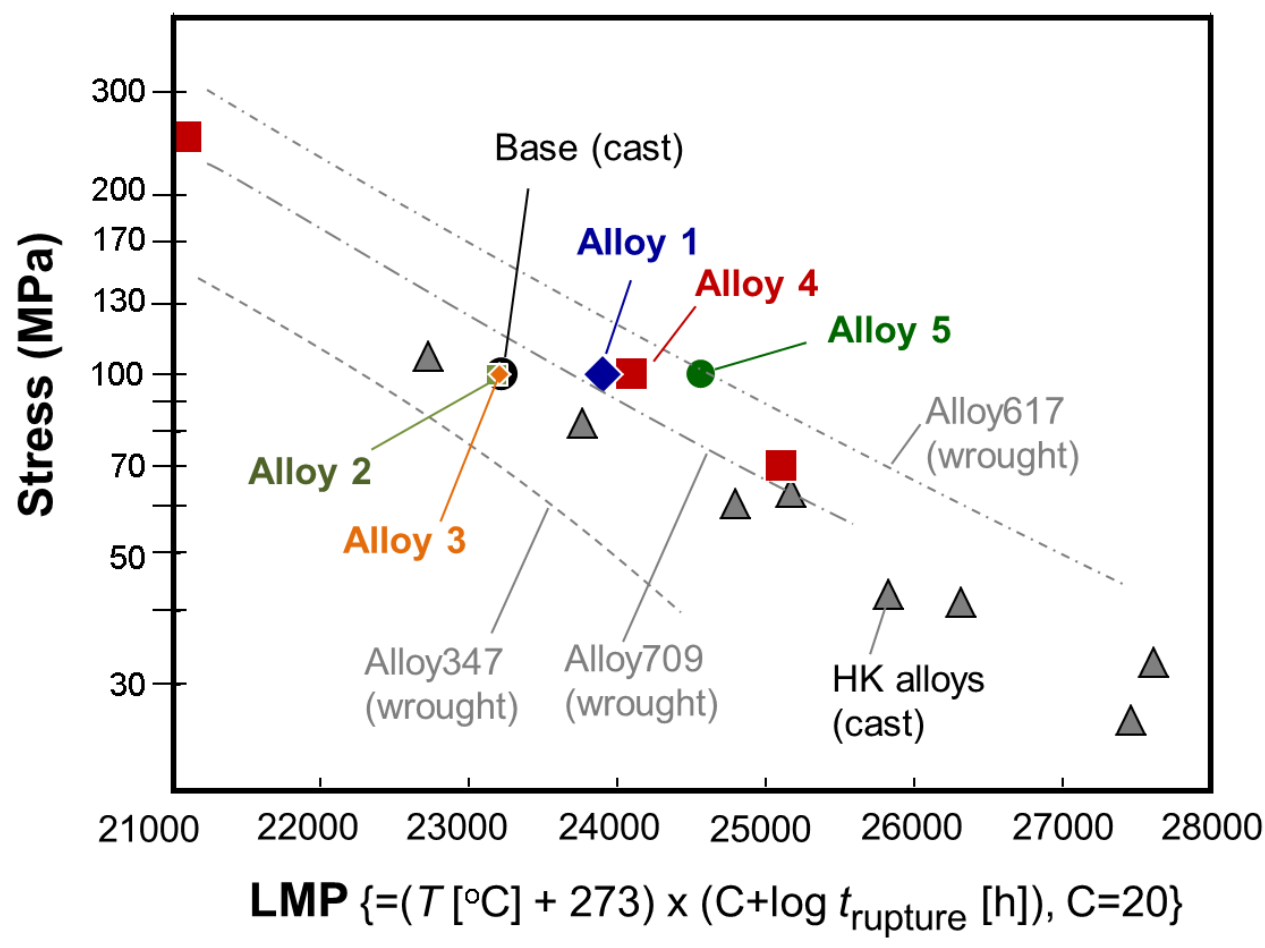

Fig. 40. Larson-Miller parameter creep resistance plot showing the cast AFA alloys relative to cast commercial chromia-forming HK austenitic alloys.

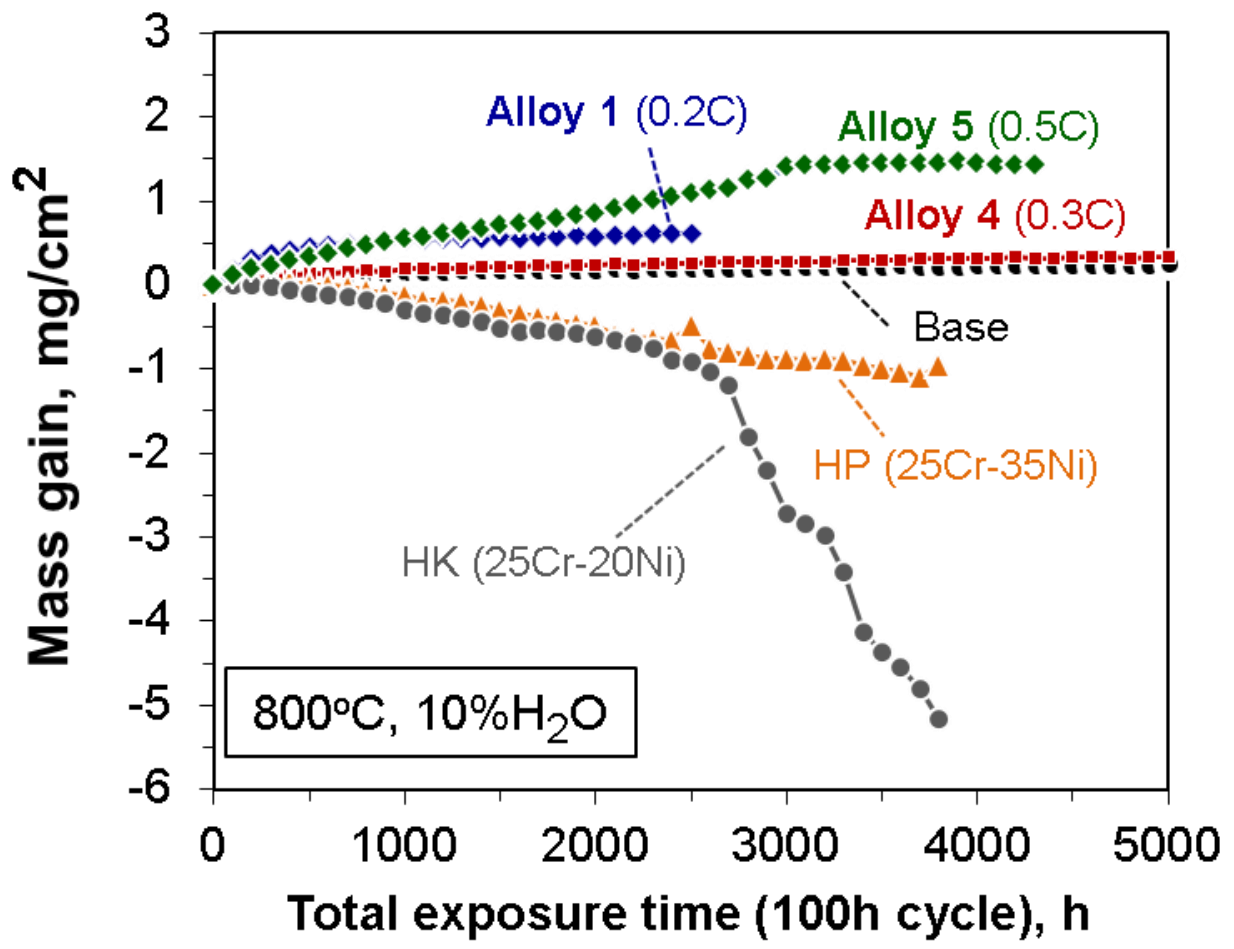

Fig. 41. Oxidation data at $800^{\circ} \mathrm{C}$ in air with $10 \%$ water vapor showing the cast AFA alloys relative to cast commercial chromia-forming $\mathrm{HK}$ and $\mathrm{HP}$ austenitic alloys. 
The cast AFA alloy data generated to date shows great promise for this new grade of AFA alloys. As discussed in commercialization activities section 3.1, Duraloy Technologies was able to successfully centrifugally cast a downselected AFA composition in tube form. Further development and assessment work for this new grade of AFA alloys is needed, in particular creep and oxidation evaluation of the Duraloy cast material to determine if the lab scale level of properties are obtained in commercial scale casting. A potential issue for cast AFA alloys is their susceptibility to detrimental AlN precipitate formation, which may be encountered in lower cost air casting component production. The composition cast by Duraloy contained alloy additions designed to getter away $\mathrm{N}$ from the $\mathrm{Al}$ to prevent coarse, acicular AlN formation, which is associated with degradation of both creep and oxidation resistance in AFA alloys. 


\section{BENEFITS ASSESSMENT}

This section is based on analysis performed by ORNL in DE2012-1041321 "Alumina-Forming Austenitics: A New Approach to Thermal and Degradation Resistant Stainless Steels for Industrial Use" by Carpenter Technology Corporation and ORNL.

Government Performance and Results Act (GPRA) analysis for potential impacts of AFA stainless steels were conducted in 2009 (Table 8). These estimates considered impacts of AFA in the Chemical Processing, Petroleum Refining, and Steam Boilers Industry. AFA alloys were assumed applicable to $15 \%$ of processes and that AFA alloys will yield a $30 \%$ improvement in process efficiency through higher temperature operation and reductions in shutdown enabled by longer-lived materials. For petroleum refining applications, a $20 \%$ improvement in processing efficiency was assumed to be possible through raising operating temperatures and by eliminating shutdowns for maintenance and repair. AFA alloys were assumed to be ultimately used in $20 \%$ of the available market; however, in higher temperature applications such as steam methane reforming of hydrogen, it was noted that the ultimate adoption rate could be much higher. For steam boilers, the 2006 Manufacturing Energy Consumption Survey (MECS) data from the Energy Information Agency (EIA) indicated consumption of 5.5 quads annually for industrial steam generation in the pulp \& paper, plastics \& rubber, non-metal mineral (glass and cement) and primary metals industries. If $45 \%$ of this energy is used to raise steam, and $10 \%$ of this market is captured, ultimately $5 \%$ of this total can be affected. Assumed process improvements of $25 \%$ due to raising operating temperatures and by eliminating shutdowns for maintenance and repair were anticipated. In all cases, initial commercialization of AFA alloy material in operating plants was assumed to occur in 5 years (2014), and full market penetration at $15 \%$ of potential sites was assumed to occur by 2020 .

Table 8. GPRA analysis for potential impacts of AFA stainless steels

\begin{tabular}{|c|c|c|c|}
\hline \multicolumn{2}{|l|}{2009 Estimate } & Impact in 2020 & $\begin{array}{c}\text { Cumulative Impact } \\
\text { Through } 2020\end{array}$ \\
\hline \multicolumn{4}{|l|}{ Energy Metrics } \\
\hline Total Primary & Chemical Processing & 36 & 100 \\
\hline Energy & Petroleum Refining & 10 & 24 \\
\hline Displaced & Steam Boilers-Other & $\underline{11}$ & $\underline{32}$ \\
\hline (trillion Btu) & Total & 57 & 156 \\
\hline \multicolumn{4}{|c|}{ Financial Metrics } \\
\hline \multirow{4}{*}{$\begin{array}{l}\text { Net Economic } \\
\text { Benefit (\$ } \\
\text { million/year) }\end{array}$} & Chemical Processing & 410 & 1150 \\
\hline & Petroleum Refining & 65 & 182 \\
\hline & Steam Boilers-Other & $\underline{51}$ & 142 \\
\hline & Total & 526 & 1474 \\
\hline \multicolumn{4}{|c|}{ Environmental Benefits } \\
\hline \multirow{4}{*}{$\begin{array}{l}\mathrm{CO}_{2} \text { Emissions } \\
\text { Displaced } \\
\text { (million TCE) }\end{array}$} & Chemical Processing & 0.5 & 1.5 \\
\hline & Petroleum Refining & 0.2 & 0.5 \\
\hline & Steam Boilers-Other & $\underline{0.2}$ & $\underline{0.5}$ \\
\hline & Total & 0.9 & 2.5 \\
\hline
\end{tabular}

Based on the findings of the present effort, DE2012-1041321 "Alumina-Forming Austenitics: A New Approach to Thermal and Degradation Resistant Stainless Steels for Industrial Use" and a CRADA with Carpenter (CRADA No. NFE-10-02715 Assessment of AFA Stainless Steels for Tube Products in Chemical Processing and Energy Production Applications), the AFA alloys still show excellent potential for significantly improved durability in these applications. However, the findings also 
suggest a narrower window of applicability than initially estimated, due to the lessening of the AFA corrosion resistance advantage over commercial austenitic and Ni-base alloys at the lower < 550$600^{\circ} \mathrm{C}$ temperature range of interest in many environments, and a slower timetable to commercial adoption. The latter is due in part to the long lead time needed to manufacture multiple specific wrought AFA product forms and sizes for industrial end users (each user typically needs different forms and sizing; (see Commercial Demonstrations), and the need by potential end users for long-term (multi-year) field evaluation of trial components before adoption. Further, a definitive advantage for AFA in metal dusting screening conditions was not observed in laboratory scale testing (see Environmental Effects), with poor results for OC-4 AFA grade alloys also reported by an industrial end user in field exposures. Therefore, the revised calculations shown in Table 9 assume applicability to only $5 \%$ of processes. Market penetration of $10 \%$ was assumed by 2020 , and $50 \%$ in 2025 . As can be seen, although the impact is lessened relative to the 2009 estimate, it still indicates significant potential energy savings, environmental benefits, and net economic benefit of commercialization of the AFA alloy class.

It should be noted that promising early laboratory results for $\mathrm{AFA}^{\mathrm{LN}}$ grade of alloys in metal dusting conditions were recently reported by an industrial end user partner of Carpenter (see section 3.3 Task 3). The behavior was, surprisingly, far better than that of OC-4 despite the lower alloy content and cost of $\mathrm{AFA}^{\mathrm{LN}}$ (Table 1). Additional test samples of $\mathrm{AFA}^{\mathrm{LN}}$ were supplied and evaluation will continue in 2013-2014. Test coupons for field exposures will also be supplied. If the $\mathrm{AFA}^{\mathrm{LN}}$ grade proves viable for improved metal dusting resistance, benefits in chemical promising could approach original 2009 estimates in Table 8.

Table 9. Revised GPRA analysis for potential impacts of AFA stainless steels

\begin{tabular}{|c|c|c|c|}
\hline & & Impact in 2020 & $\begin{array}{c}\text { Cumulative Impact } \\
\text { Through } 2025\end{array}$ \\
\hline \multicolumn{4}{|l|}{ Energy Metrics } \\
\hline Total Primary & Chemical Processing & 8 & 145 \\
\hline Energy & Petroleum Refining & 8 & 146 \\
\hline Displaced & Steam Boilers-Other & $\underline{7}$ & $\underline{128}$ \\
\hline (trillion Btu) & Total & 23 & 419 \\
\hline \multicolumn{4}{|c|}{ Financial Metrics } \\
\hline \multirow{4}{*}{$\begin{array}{l}\text { Net Economic } \\
\text { Benefit (\$ } \\
\text { million/year) }\end{array}$} & Chemical Processing & 94 & 1794 \\
\hline & Petroleum Refining & 58 & 1126 \\
\hline & Steam Boilers-Other & $\underline{31}$ & $\underline{594}$ \\
\hline & Total & 183 & 3514 \\
\hline \multicolumn{4}{|c|}{ Environmental Benefits } \\
\hline \multirow{4}{*}{$\begin{array}{l}\mathrm{CO}_{2} \text { Emissions } \\
\text { Displaced } \\
\text { (million TCE) }\end{array}$} & Chemical Processing & 0.1 & 2.3 \\
\hline & Petroleum Refining & 0.1 & 2.6 \\
\hline & Steam Boilers-Other & $\underline{0.1}$ & 1.8 \\
\hline & Total & 0.3 & 6.7 \\
\hline
\end{tabular}




\section{COMMERCIALIZATION}

This section is based on analysis performed by Carpenter in DE2012-1041321 "Alumina-Forming Austenitics: A New Approach to Thermal and Degradation Resistant Stainless Steels for Industrial Use". The major commercialization tasks pursued under this program were described in section 3.1 Commercial Demonstrations. From a technical perspective, commercialization activities are driven by AFA alloy cost and property performance in specific high-temperature oxidizing environments and/or creep conditions relative to existing alloys. Testing of AFA alloy grades was pursued for a wide range of high-temperature applications/environments by ORNL, Carpenter, and numerous industrial and academic collaborators (Table 10).

Table 10. Overview of potential AFA applications and estimated degree of commercialization promise

\begin{tabular}{|c|c|c|}
\hline Applications/Conditions & $\begin{array}{c}\text { *ORNL Estimate for AFA } \\
\text { Potential 1-10 Scale (1=low, } 10= \\
\text { high) }\end{array}$ & Comments \\
\hline $\begin{array}{l}\text { Turbine Recuperators, Combustion } \\
\text { Environments }\end{array}$ & 10 & $\begin{array}{l}\text { AFA has needed levels of } \\
\text { oxidation and creep resistance, } \\
\text { challenge is supply chain for varied } \\
\text { foil product forms needed }\end{array}$ \\
\hline Supercritical $\mathrm{H}_{2} \mathrm{O}$ & 7 & $\begin{array}{l}\text { AFA showed good promise in } \\
\text { academic partner lab testing }\end{array}$ \\
\hline Steam Boiler & 7 & $\begin{array}{l}\text { AFA has excellent steam } \\
\text { resistance. Applicability depends } \\
\text { on creep and target temperature ( } \leq \\
700^{\circ} \mathrm{C} \text { limit) }\end{array}$ \\
\hline $\begin{array}{l}\text { Solid Oxide Fuel Cell (SOFC) } \\
\text { Balance of Plant }\end{array}$ & 7 & $\begin{array}{l}\text { AFA shows good promise } \leq 900^{\circ} \mathrm{C} \text {. } \\
\text { Higher temperatures needed by } \\
\text { some designs, SOFC not yet fully } \\
\text { commercialized }\end{array}$ \\
\hline Aggressive Process Environments & 7 & $\begin{array}{l}\text { AFA shows promise in oxidation- } \\
\text { sulfidation and carburization } \\
\text { (carbon activity }<1 \text { ). Nitridation } \\
\text { conditions likely poor for AFA due } \\
\text { to Al/AlN reaction }\end{array}$ \\
\hline Supercritical $\mathrm{CO}_{2}$ & 5 & $\begin{array}{l}\text { Limited data from academic } \\
\text { partner lab testing. Comparable, } \\
\text { lesser than conventional alloys thus } \\
\text { far. More data and AFA grades } \\
\text { need to be evaluated }\end{array}$ \\
\hline Molten Salts & 3 & $\begin{array}{l}\text { Mixed results in partner testing and } \\
\text { literature. Possible promise in } \\
\text { concentrating solar power nitrates, } \\
\text { poor behaviour in carbonates }\end{array}$ \\
\hline Metal Dusting/Reforming & 3 & $\begin{array}{l}\text { Poor results in field testing for } \\
\text { AFA grade OC-4. Positive early } \\
\text { results for AFA }{ }^{\mathrm{LN}} \text { grade alloys- } \\
\text { more study and alloy development } \\
\text { needed }\end{array}$ \\
\hline
\end{tabular}




\begin{tabular}{|l|l|l|}
\hline Fireside Boiler & 3 & $\begin{array}{l}\text { Poor results in lab testing for AFA } \\
\text { grade OC-4. Positive early results } \\
\text { for high Cr, Ni AFA superalloy } \\
\text { grade- more study and alloy } \\
\text { development needed }\end{array}$ \\
\hline Molten Metals & $\begin{array}{l}\text { Poor behaviour reported by partner } \\
\text { in Galvalume baths (Al-Zn). Clear } \\
\text { advantage of alumina formation for } \\
\text { molten metals not obvious }\end{array}$ \\
\hline
\end{tabular}

Discussions of the commercialization outlook for several of the most promising AFA applications are provided below.

\subsection{RECUPERATED TURBINES}

Turbines use recuperators in order to improve their overall efficiency. Recuperated gas turbine cycles are used predominantly in microturbines with generating output less than $1 \mathrm{MW}$. Recuperated turbines are also used primarily for power generation industry applications. Exceptions include Rolls Royce's WR-21 (used for marine applications) and the Honeywell AGT1500 (M1 Abrams tank). Growth in microturbines is expected to be fueled by a trend toward distributed generation (DG). Distributed generation refers to the production of electricity at or near the place of consumption. Examples of DG include backup generators at hospitals, solar power systems on residential rooftops, and combined heat and power systems at university campuses.

Among the energy technologies frequently mentioned for distributed generation are fuel cells, solar photovoltaic cells, and wind-powered generators. However, the Energy Information Agency's (EIA) 2011 outlook anticipates strong growth for distributed generation, with microturbines singled out as the fastest-growing DG technology, with growth "averaging 16\% per year." The EIA data suggests approximately 2.5 million KW of additional microturbine capacity will be added to the US from 20092035. Therefore the US total market potential for AFA recuperator foil thru 2035 is about 5,000 tons, assuming and average turbine size of $65 \mathrm{KW}$ with 200 to $400 \mathrm{lbs}$ of AFA required per unit (Table 11). The global market is likely a factor of two to three times larger.

Table 11. US market potential for AFA in Microturbines

\begin{tabular}{|l|r|l|}
\hline \multicolumn{3}{|c|}{ Market Potential for AFA in Microturbines } \\
\hline KW added 2009-2035 & $2,500,000$ & \\
\hline Avg KW per unit & 65 & \\
\hline \# Turbines 2009-2035 & 38,462 & \\
\hline of which small recuperator & 30,769 & use 200lbs @ \\
\hline of which large recuperator & 7,692 & use 400lbs @ \\
\hline Recuperator Alloy (tons) & 4,615 & Tons \\
\hline \hline Annualized (2009-2035) & 171 & TPY \\
\hline
\end{tabular}

(DE2012-1041321 "Alumina-Forming Austenitics: A New Approach to Thermal and Degradation Resistant Stainless Steels for Industrial Use")

Recuperators preheat the air used in the combustor in order to reduce fuel consumption in the combustor and increase efficiency. Most recuperators operate at a maximum temperature of $\sim 600$ to $750^{\circ} \mathrm{C}$. Recuperators are exposed to turbine exhaust, which is a complex mixture of combustion byproducts (particularly water vapor) and air. Common materials used are the high Ni austenitic HR120, the Ni-base alloy 625, and type 347 stainless steel. The AFA alloys offer an attractive lower cost 
alternative to HR-120 and 625 when temperatures of operation exceed $600-650^{\circ} \mathrm{C}$ (347 no longer viable at these temperatures due to accelerated oxidation attack in water vapor).

\subsection{COAL-FIRED AND RELATED STEAM POWER PLANTS}

In its 2010 World Energy Outlook, the International Energy Agency projects that coal-powered electricity generation will remain the largest source of electricity generation through 2035. Coal's resilience as a source of electrical power generation is due to its abundance, low cost and proven reliability in baseload operations. Coal-fired power generation is expected to become increasingly efficient as new installations migrate from subcritical to ultra-supercritical technologies. Drivers for advanced coal technologies include lower emissions and improved efficiency.

The migration to ultra-supercritical (USC) temperatures is expected to occur from 2020-2035. The slow adoption is due to ongoing concept and technology validation thru 2020, to include the validation of materials that will perform at the higher temperatures and pressures. The two main components of the coal-fired power plant are the boiler and the steam turbine. In the boiler, the coal is combusted and the bulk of the components (waterwalls, superheater, reheater, header) are made of tubing and pipe carrying the superheated steam and mixed liquids.

The expanding steam drives the steam turbine, which is the simplest and most efficient engine to convert heat energy to work. The key components of the turbine are very similar to those of an aerospace gas turbine engine (rotors/discs, blades/vanes, casings/cylinders, fasteners), but the materials must survive the more aggressive environment of superheated steam. The rotors and casings pose the most significant material challenges because of the extremely demanding requirements as well as the need for much larger section sizes compared to those used in aerospace turbines. The same challenges apply to the boiler tubing and pipe except that formability and weldability replaces section size concerns.

In order to operate in advanced USC conditions, alloys must meet the following performance criteria: 1. Long-term creep strength $-100,000$ hours at up to $760^{\circ} \mathrm{C}$

2. Hot corrosion - coal ash, erosion, corrosion fatigue, SCC

3. Oxidation - superheated steam up to $760^{\circ} \mathrm{C}$, steamside oxidation is a limiting factor

4. Long-term stability - 100,000 hours minimum, 30-year design life for plant

5. Formability - large forgings for rotors, tube manufacture and bending for boilers

6. Weldability - for welded rotors/casings and tube assemblies

7. Fatigue

Higher pressures and temperatures necessitate the use of higher-performance and higher-cost materials. For example, advanced USC conditions could result in $\sim 2 \mathrm{M}$ lbs of nickel-based tubes used in a generic boiler (Mike Santella, 25th Annual Conference on Fossil Energy Materials, Portland, OR, 04/28/11). EPRI reports that a plant operating at $\sim 700^{\circ} \mathrm{C}$ will incur installation costs of high-nickel alloy piping 3x greater than for supercritical plants (John Wheeldon, Introduction to Advanced UltraSupercritical Workshop, 04/07/11). Nickel-based materials are also candidates for steam turbine components as temperatures increase. Components made from both wrought and cast alloys such as buckets, nozzles, rotors, casing, and bolting are of interest. The AFA stainless steels should be considered as lower cost alternatives to Ni base alloys in some USC steam boiler and turbines components. The excellent steam oxidation resistance of current AFA grade alloys (Table 1) may be a significant benefit in these applications, but they are limited to $\leq 700^{\circ} \mathrm{C}$ for the components requiring the highest levels of creep resistance, and are also susceptible to fireside attack. The AFA superalloy grade (Table 1) possesses better creep resistance and fireside corrosion resistance than the AFA grade 
in the $600-750^{\circ} \mathrm{C}$ range of interest. However, further development and evaluation of this AFA superalloy grade is needed, particularly relative to advanced austenitics developed for USC, such as Sanicor 25, and Ni-base alloys. For the most demanding USC applications, code case evaluation will be needed, which is a costly, multi-year endeavor and a major hurdle for AFA grade alloys to overcome.

\subsection{PETROCHEMICAL}

There are more than 3,400 refining processing units installed globally addressing processes such as crude distillation, coking, visbreaking, fluid catalytic cracking, catalytic reforming, and hydroprocessing (hydro-treating and hydro-cracking). Chemical and mechanical engineering advances are continually sought after to accommodate new products and improve plant efficiency, reliability, and safety while decreasing emissions and pollutants. The International Energy Agency estimates that there will be $\$ 1$ trillion of refining infrastructure investment from 2010-2035 (World Energy Outlook, 2010) (Table 12).

Table 12. Worldwide Refining Process Units

\begin{tabular}{|c|c|c|c|c|c|c|}
\hline \multicolumn{7}{|c|}{ Worldwide Refining Process Units (as of 01/04) } \\
\hline & $\begin{array}{c}\text { Crude } \\
\text { Distillation }\end{array}$ & $\begin{array}{c}\text { Coking + } \\
\text { Visbreaking }\end{array}$ & FCC & $\begin{array}{c}\text { Catalytic } \\
\text { Reforming }\end{array}$ & $\begin{array}{c}\text { Hydro- } \\
\text { treating }\end{array}$ & $\begin{array}{c}\text { Hyrdo- } \\
\text { cracking }\end{array}$ \\
\hline \# of Units & $>710$ & $>330$ & 360 & 550 & 1,316 & 168 \\
\hline $\begin{array}{c}\text { Total World } \\
\text { Capacity } \\
\text { (million } \\
\text { barrels/day) }\end{array}$ & 82.0 & 8.0 & 14.3 & 11.3 & 40.3 & 4.6 \\
\hline $\begin{array}{c}\text { Average } \\
\text { Capacity } \\
\text { (barrels/day) }\end{array}$ & 114,000 & 45,700 & 39,700 & 20,500 & 30,600 & 27,400 \\
\hline
\end{tabular}

(Chart source: Chapter 7, Practical Advances in Petroleum Processing, Volume 1, Edited by Chang S. Hsu, ExxonMobil Research and Engineering Company, Baton Rouge, Louisiana, USA, and, Paul R. Robinson PQ Optimization Services, Katy, Texas, USA as of 01/04)

Materials play a critical role in the safe and economical functioning of petrochemical facilities. The American Petroleum Institute (API) has developed simplified flow diagrams for several process units commonly found in refineries, mapping them to primary damage mechanisms. A summary of a limited number of damage mechanisms for the main refining processes is shown in Table 13. Note that this assessment focused on a limited number of damage mechanisms that the AFA alloys are best suited to address. Sulfidation, oxidation and creep are the common damage mechanisms across refining processes. Metal dusting and carburization are also significant, though less pervasive. (API Recommended Practice 571, September 2010). AFA alloys are an attractive candidate for these applications. 
Table 13. Damage Mechanisms in Refining Processes

\begin{tabular}{|l|c|c|c|c|}
\hline \multicolumn{4}{|c|}{ Damage Mechanisms in Refining Processes } \\
\hline Refining Process & Sulfidation & Oxidation & Carburization & Metal Dusting \\
\hline Crude Unit/Vacuum & $\mathrm{x}$ & $\mathrm{x}$ & & \\
\hline Coking & $\mathrm{x}$ & $\mathrm{x}$ & $\mathrm{x}$ & \\
\hline Visbreaking & $\mathrm{x}$ & $\mathrm{x}$ & $\mathrm{x}$ & \\
\hline Fluid Cat. Cracking (FCC) & $\mathrm{x}$ & $\mathrm{x}$ & $\mathrm{x}$ & \\
\hline Hydro-processing & $\mathrm{x}$ & & & \\
\hline Catalytic Reforming & & $\mathrm{x}$ & $\mathrm{x}$ & $\mathrm{x}$ \\
\hline Sulfur Recovery & $\mathrm{x}$ & $\mathrm{x}$ & & \\
\hline Hydrogen Reforming & & $\mathrm{x}$ & & $\mathrm{x}$ \\
\hline
\end{tabular}




\section{ACCOMPLISHMENTS}

\section{Task 1. Commercial Demonstrations}

-The three core AFA alloy family patent portfolio was licensed by Carpenter on April 7, 2011.

-Manufacture of AFA on a commercial production scale was demonstrated by a successful 10,000 lb heat by Carpenter and a $2300 \mathrm{lb}$ heat by MetalWerks. Manufacturing protocols to process this material in strip, foil, wire, and tube form were developed.

-The ability to manufacture AFA foil into air cell recuperator form was demonstrated by Capstone Turbine Corporation and Solar Turbines, Inc. Engine testing of these cells will be pursued in 2013 and 2014

-Evaluation of AFA for SOFC heat exchanger applications by UTRC/UConn found promising low rates of $\mathrm{Cr}$ release (Cr contamination can degrade SOFC stacks). UTRC was further able to demonstrate that AFA foil was amenable to brazing needed for heat exchanger manufacture.

-Duraloy Technologies Inc. successfully manufactured $\sim 4.7 \mathrm{~m}$ long tubes with a 95mm OD and $\sim 16 \mathrm{~mm}$ wall thickness using established centrifugal casting techniques form a cast AFA grade developed under Task 4 of this effort.

-Test samples of various grades of AFA alloys were widely distributed to potential industrial end users and academic institutions for evaluation and study.

\section{Task 2. Property Database Development}

-A database was developed for the baseline AFA grade OC-4 alloy with characterization for thermal expansion, thermal conductivity, modulus, tensile strength (solution annealed and aged), low cycle fatigue (solution annealed and aged), creep resistance and high-temperature oxidation and corrosion resistance. This data is needed by designers for their assessment of AFA alloys.

-Creep and oxidation/corrosion test data for OC-4 in plate and foil form, with some conditions exceeding $5000 \mathrm{~h}$ duration were generated.

-Creep studies of welded OC-4 indicated creep strength comparable to the base material, with only a small weld creep rupture life reduction factor.

\section{Task 3. Alloy Development and Optimization}

- Continued successful development of higher temperature capable $\mathrm{AFA}^{\mathrm{HP}}$ grade alloys, which have a higher maximum use temperature of $950^{\circ} \mathrm{C}$.

- Continued successful development of lower $\mathrm{Ni}$ and $\mathrm{Nb}$ level (i.e. lower cost) AFA grade alloys that are amenable to lower temperature processing.

- Continued successful optimization and development of low cost, $\mathrm{AFA}^{\mathrm{LN}}$ grade alloys were successfully optimized and evaluated. Preliminary results from an industrial end user partner of Carpenter indicated corrosion resistance potential of the $\mathrm{AFA}^{\mathrm{LN}}$ grade alloys under metal dusting 
conditions (encountered in gas reforming and chemical/petrochemical processing). Evaluations by Carpenter's partner will continue in 2013-2014.

-Discovery of metastable $\gamma^{\prime}-\mathrm{Ni}_{3} \mathrm{Al}$ phase in baseline AFA grade OC-4 alloys resulted in design basis for a new class of AFA superalloys, which led to a secondary research project funded by DARPA.

\section{Task 4. Evaluation of As-Cast Properties}

-A new grade of AFA alloys amenable to casting was successfully developed: Cast Alumina Forming Austenitic Stainless Steels, US 8,431,072 B2 Apr. 30, 2013. Tube manufacture was successfully demonstrated by Duraloy Technologies (see Task 1 accomplishments).

\subsection{PUBLICATIONS AND PRESENTATIONS}

-B. A. Pint, "Deployment of New High-Temperature Alloys for Power Generation Systems," invited presentation at TMS Annual Meeting, Seattle, WA, February, 2010.

-B. A. Pint, "Deployment of New High-Temperature Alloys for Power Generation Systems," presentation at NACE Corrosion 2010, San Antonio, TX, March, 2010.

-B. A. Pint, M. P. Brady, Y. Yamamoto, M. L. Santella, P. J. Maziasz and W. J. Matthews, (2010) "Evaluation of Alumina-Forming Austenitic Foil for Advanced Recuperators," ASME Paper \#GT2010-23003, presented at the International Gas Turbine \& Aeroengine Congress \& Exhibition, Glasgow, Scotland, June, 14-18, 2010.

- "Effect of Temperature and Water Vapor on the Oxidation of an Alumina-Forming Austenitic Steel," presentation at the Material Science and Technology 2010 (MS\&T2010) conference held in Houston, TX in October 2010.

-"Effect of Water Vapor Content on the Resistance to Metal Dusting of Fe- and Ni-Base Alloys," presentation at the Material Science and Technology 2010 (MS\&T2010) conference held in Houston, TX in October 2010.

-"Multi-phase strengthening of alumina-forming, creep-resistant austenitic stainless steel alloys at 650$750^{\circ} \mathrm{C}$," presentation at the Material Science and Technology 2010 (MS\&T2010) conference held in Houston, TX in October 2010.

-"Effect of Microstructural Evolution during Solidification on the Creep and Oxidation Resistance of Alumina-Forming Austenitic Stainless Steel Alloys," presentation at the Material Science and Technology 2010 (MS\&T2010) conference held in Houston, TX in October 2010.

-Presentation entitled "Creep deformation behavior of alumina forming austenitic (AFA) stainless steel alloy Fe-25Ni-14Cr-3.5Al-2.5Nb-0.1wt\%C (OC4), between $650^{\circ} \mathrm{C}$ and $750^{\circ} \mathrm{C}$," was made at the TMS Annual Meeting, February 2011 in San Diego, CA.

-Presentation entitled "Oxidation Behavior of Alumina-Forming Austenitic Steel in Steam," was made at the TMS Annual Meeting, February 2011 in San Diego, CA.

-Presentation entitled "Development and evaluation of high Mn containing alumina-forming austenitic stainless steel alloys for advanced steam conditions," was made at the TMS Annual Meeting, February -2011 in San Diego, CA.

Y. Yamamoto, M.P. Brady, M.L. Santella, H. Bei, P.J. Maziasz, B.A. Pint, "Overview of Strategies for High-Temperature Creep and Oxidation Resistance of Alumina-Forming Austenitic Stainless Steels", Metallurgical and Materials Transaction A, Volume 42, Number 4, pp. 922-931 (2011).

-M.P. Brady, K.A.Unocic, M.J. Lance, M.L. Santella, Y. Yamamoto, and L.R. Walker, "Increasing the Upper Temperature Oxidation Limit of Alumina Forming Austenitic Stainless Steels in Air with Water Vapor", Oxidation of Metals, Volume 75, Numbers 5-6, 337-357 (2011). 
-Paper was published in proceedings (\#11-157) and presentation made at NACE Corrosion 2011

conference in Houston, TX, March 2011 entitled "Performance of Alumina-Forming Austenitic Steels, Fe-base and Ni-base alloys exposed to metal dusting environments".

-Presentation and associated paper entitled "Evaluation of Commercial Alumina-Forming Austenitic Foil for Advanced Recuperators," was made at the International Gas Turbine \& Aeroengine Congress \& Exhibition, Vancouver, Canada, June, 2011.

-Presentation at TMS Annual Meeting, 2012, Development of Cast Alumina-Forming Austenitic Stainless Steel Alloys

-K. A. Unocic, M. P. Brady, B. A. Pint and A. Rouaix-Vande Put (2013) "Oxidation Behavior of Alumina-Forming Austenitic Steel," NACE Paper 13-2172, Houston, TX, presented at NACE Corrosion 2013, Orlando, FL, March, 2013.

-B. A. Pint, S. Dryepondt, M. P. Brady and Y. Yamamoto, (2013) "Evaluation of Commercial and Next Generation Alumina-Forming Austenitic Foil for Advanced Recuperators," ASME Paper \#GT2013-94940, published and presented at the International Gas Turbine \& Aeroengine Congress \& Exhibition, San Antonio, TX, June, 3-7, 2013.

-Presentation at TMS Annual Meeting, March 2013, Recent developments in creep-resistant, aluminaforming austenitic stainless steels

-Y.Yamamoto, M. Govindarajan, M.1 P. Brady, Development of L12-ordered $\mathrm{Ni}_{3}(\mathrm{Al}, \mathrm{Ti})$ strengthened alumina-forming austenitic stainless steel alloys, Scripta Materialia (in press)

-M.P. Brady, J. Magee, Y Yamamoto, D. Helmick, and L. Wang, Co-Optimization of Wrought Alumina-Forming Austenitic Stainless Steel Composition Ranges for High-Temperature Creep and Oxidation/Corrosion Resistance, accepted for publication in Materials Science and Engineering A -G. Muralidharan, Y. Yamamoto, and M. P. Brady, Development of a Cast, Alumina-Forming Austenitic Stainless Steel, journal paper to be submitted

-A.Rouaix-Vande Put, K. A. Unocic, M.P. Brady, B. A. Pint, Performance of Chromia- and AluminaForming Fe- and Ni-base alloys exposed to metal dusting environments: The effect of water vapor and temperature, journal paper to be submitted

\subsection{INTELLECTUAL PROPERY}

U.S. patent 8,431,072, "Cast Alumina Forming Austenitic Stainless Steels" was issued on April 30, 2013.

Three core AFA patents were licensed by Carpenter on April 7, 2011 


\section{CONCLUSIONS}

The purpose of this project was to accelerate the development and deployment of a new family of heatresistant alloys developed at ORNL: alumina-forming austenitic (AFA) stainless steels. Initial laboratory scale evaluation indicated that the AFA alloys possess exceptional high-temperature oxidation resistance while retaining creep properties similar to other advanced austenitic stainless steels. The AFA steels therefore represent a low-cost alternative to Ni-base alloys and a highperformance alternative to conventional advanced austenitic steels. Deployment of AFA steels into turbine and other energy-related applications can lead to improved efficiencies by achieving higher performance levels (e.g. operation temperature) and/or improved durability and component lifetime at costs comparable to currently used alloys.

The primary conclusions of this project are:

AFA stainless steels are amenable to established commercially used manufacturing methods and can be made in sheet, foil, and tube form. They generally require high solutionizing temperatures $\left(1200^{\circ} \mathrm{C}\right)$ for amenability to hot/cold working and to achieve optimal creep properties. However, compositions with a good balance of creep and oxidation resistance were also identified that can tolerate lower solutionizing temperatures $\left(1050-1100^{\circ} \mathrm{C}\right)$ more widely attainable at commercial alloy post processors. Surface finish of AFA foil emerged as an issue in foil production, with the high thermodynamic stability of alumina making it difficult to eliminate oxidation during alloy processing. The presence of residual surface oxide on AFA foil complicated joining of foil form material. Commercial foils of other alumina-formers such as the $\mathrm{FeCrAl}$ class of alloys are available, and techniques used for those materials to produce a "shiny" oxide free surface finish should be adopted for AFA alloy foil product. The AFA alloy family in bulk sheet/plate form is readily weldable by conventional means with little detrimental impact on creep resistance.

A grade of AFA amenable to use in the as-cast form was successfully developed, and opens up consideration of AFA for a wide range of cast components, in addition to in initially developed wrought forms.

The AFA alloys are most suited to applications involving high temperature exposure to water vapor, steam, and $\mathrm{C}$ and/or $\mathrm{S}$ species containing process environments. AFA showed mixed corrosion resistance results in molten salts and hot corrosion conditions, and generally poor resistance in metal dusting conditions. A possible exception to metal dusting resistance is the low $\mathrm{Ni}$, low cost $\mathrm{AFA}^{\mathrm{LN}}$ grade of alloys, which in preliminary testing by an industrial collaborator showed good promise. Multiple grades of AFA alloys are possible, including the baseline AFA grade which provides corrosion resistance up to $700-850^{\circ} \mathrm{C}$; cast $\mathrm{AFA}$ for use up to $700-850^{\circ} \mathrm{C} ; \gamma^{\prime}-\mathrm{Ni}_{3} \mathrm{Al}$ strengthened $\mathrm{AFA}$ superalloy for use up to $700-850^{\circ} \mathrm{C}$ with improved creep strength; $\mathrm{AFA}^{\mathrm{HP}}$ high performance grade, with $\mathrm{Hf}, \mathrm{Zr}, \mathrm{Y}$ additions and higher $\mathrm{Al}, \mathrm{Cr}, \mathrm{Nb}$, and $\mathrm{Ni}$ levels permitting use up to $950^{\circ} \mathrm{C}$ range; and low cost $\mathrm{AFA}^{\mathrm{LN}}$ for use up to $650^{\circ} \mathrm{C}$ range. 


\section{RECOMMENDATIONS}

1) Commercialization efforts should continue for thin product form AFA sheet and for heat exchanger applications such as turbine recuperators, which involve exposure to combustion environments and high levels of water vapor where AFA alloys excel relative to currently used chromia-forming alloys. The biggest challenge will be establishment of a material supply chain, as multiple alloy post processors are needed to move from AFA production heats to the wide range of final foil product forms needed by various potential end users.

2) Intermediate term applications should focus on tube form for chemical/petrochemical process industry applications. This includes cast forms of AFA, and the wrought AFA and AFA ${ }^{\mathrm{LN}}$ grades.

3) Further study of the AFA ${ }^{\mathrm{LN}}$ grade for metal dusting environments should be pursued. Optimization for metal dusting resistance, if sufficient levels can be demonstrated, would lead to significant industrial push and an expanding market in the chemical and process industries for $\mathrm{AFA}^{\mathrm{LN}}$ tube form material

4) Increased emphasis should be placed on further development and commercialization of cast forms of AFA, as they avoid the supply chain issues and complications encountered with highly processed wrought forms such as foils. This should include both the cast AFA grade and cast forms of the AFA superalloy grade. 